Fall 2006 Semiannual (III.H. and I.U.) Report for the HWMA/RCRA Post-Closure Permit for the INTEC Waste Calcining Facility at the INL Site

January 2007 
DOE/ID-11295

Revision 0

Project No. 23518

\section{Fall 2006 Semiannual (III.H. and I.U.) Report for the HWMA/RCRA Post-Closure Permit for the INTEC Waste Calcining Facility at the INL Site}

January 2007

Prepared for the 



\begin{abstract}
The Waste Calcining Facility (WCF) is located at the Idaho Nuclear Technology and Engineering Center. In 1998, the WCF was closed under an approved Hazardous Waste Management Act/Resource Conservation and Recovery Act (HWMA/RCRA) Closure Plan. Vessels and spaces were grouted and then covered with a concrete cap. The Idaho Department of Environmental Quality issued a final HWMA/RCRA post-closure permit on September 15, 2003, with an effective date of October 16, 2003. This permit sets forth procedural requirements for groundwater characterization and monitoring, maintenance, and inspections of the WCF to ensure continued protection of human health and the environment. The post-closure permit also includes semiannual reporting requirements under Permit Conditions III.H. and I.U. These reporting requirements have been combined into this single semiannual report, as agreed between the Idaho Cleanup Project and Idaho Department of Environmental Quality.

The Permit Condition III.H. portion of this report includes a description and the results of field methods associated with groundwater monitoring of the WCF. Analytical results from quarterly groundwater sampling, the results of inspections and maintenance of monitoring wells in the WCF groundwater monitoring network, and results of inspections of the concrete cap are summarized.
\end{abstract}

The Permit Condition I.U. portion of this report includes noncompliances not otherwise required to be reported under Permit Condition I.R. (advance notice of planned changes to facility activity which may result in a noncompliance) or Permit Condition I.T. (reporting of noncompliances which may endanger human health or the environment). 


\section{CONTENTS}

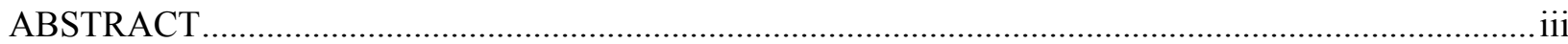

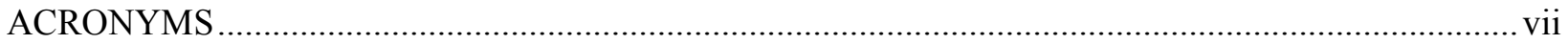

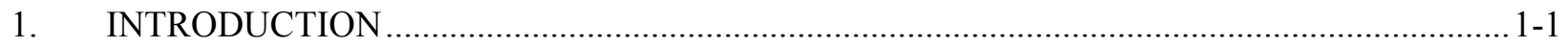

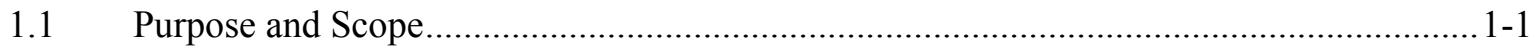

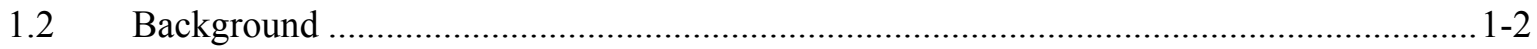

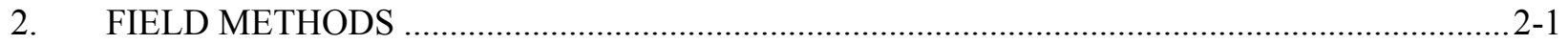

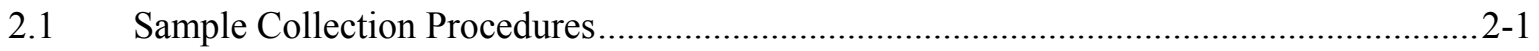

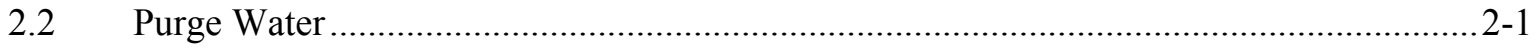

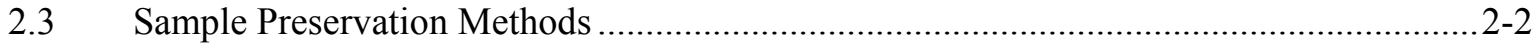

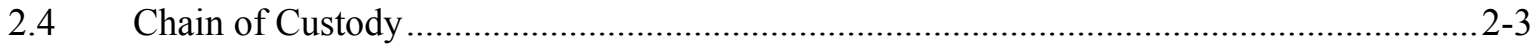

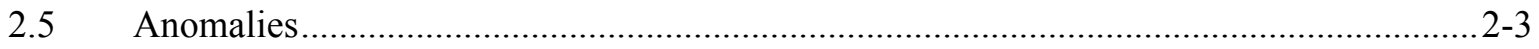

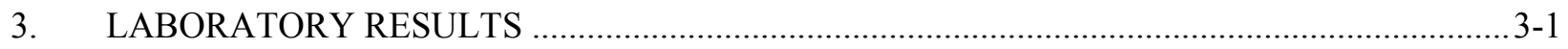

3.1 Groundwater Monitoring Data .......................................................................... $3-1$

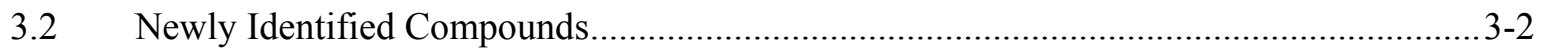

4. GROUNDWATER LEVELS, FLOW DIRECTION, AND GRADIENT …................................4-1

4.1 Water Elevation and Well Depth.......................................................................

4.2 Groundwater Flow Direction and Gradient ................................................................ $4-1$

4.3 Monitoring Well Network Compliance Statement ........................................................... 4-5

5. MAINTENANCE OF GROUNDWATER MONITORING EQUIPMENT ...................................5-1

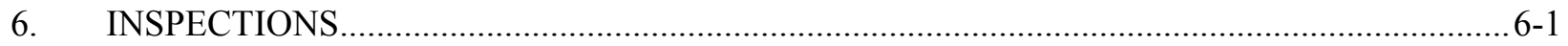

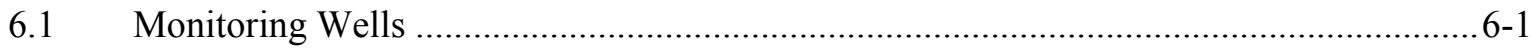

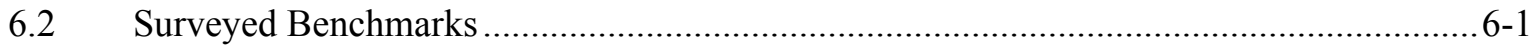

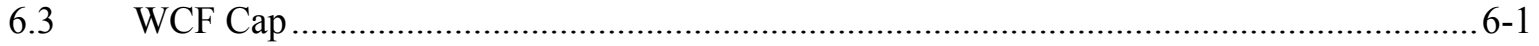

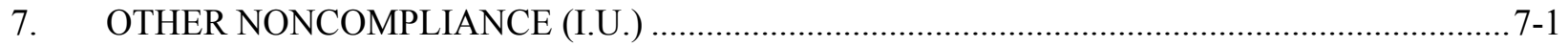

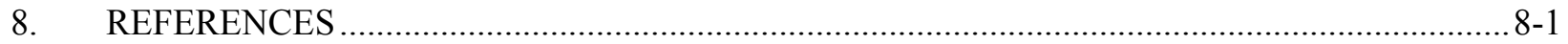




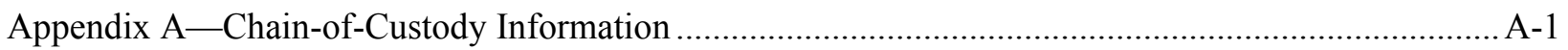

Appendix B - Groundwater Analytical Data and Quality Assurance/Quality Control Information ........ B-1

Appendix C-Assessment of Perched Water Elevations and Hydraulic Gradients: November 2005

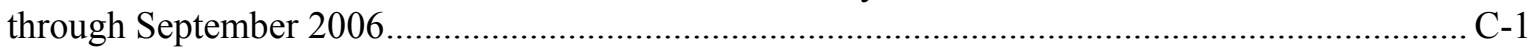

\section{FIGURES}

1-1. Groundwater monitoring network for WCF .......................................................................... 1-3

\section{TABLES}

2-1. Approximate volumes of purge water generated from sampling events ...................................2-2

2-2. Summary of sample preservation methods....................................................................... $2-2$

3-1. Constituent analyte list and associated estimated quantitation limits (EQLs) and groundwater protection standards (GPSs) (DEQ 2004) .......................................................... $3-1$

3-2. Validated unqualified barium results in WCF wells in May 2006 and August 2006 ( $\mu \mathrm{g} / \mathrm{L})$..........3-2

4-1. Shallow perched groundwater well elevations and total depths of monitoring wells....................4-2

4-2. Field-measured depth to water and water level elevations ....................................................... 4-3

5-1. Installation of groundwater monitoring equipment .................................................................. $5-1$ 


\section{ACRONYMS}

ASTM American Society for Testing and Materials

CLP Contract Laboratory Program

CME Comprehensive Groundwater Monitoring Evaluation

COC chain of custody

DEQ (Idaho) Department of Environmental Quality

DOE-ID Department of Energy Idaho Operations Office

EPA Environmental Protection Agency

EQL estimated quantitation limit

GC-MS gas chromatography-mass spectrometry

GPS groundwater protection standard

HWMA Hazardous Waste Management Act

ICAL initial calibration

ICP Idaho Cleanup Project

INL Idaho National Laboratory

INTEC Idaho Nuclear Technology and Engineering Center

LCS laboratory control sample

LCSD laboratory control sample duplicate

MS matrix spike

MSD matrix spike duplicate

NCR nonconformance report

PMR permit modification request

QA/QC quality assurance/quality control

RCRA Resource Conservation and Recovery Act

RPD relative percent difference

RRF relative response factor 


$\begin{array}{ll}\text { RSD } & \text { relative standard deviation } \\ \text { SAM } & \text { Sample and Analysis Management } \\ \text { SVOC } & \text { semivolatile organic compound } \\ \text { SWRI } & \text { Southwest Research Institute } \\ \text { TFS } & \text { tank farm south } \\ \text { TFSE } & \text { tank farm southeast } \\ \text { VOC } & \text { volatile organic compound } \\ \text { WCF } & \text { Waste Calcining Facility }\end{array}$




\section{Fall 2006 Semiannual (III.H. and I.U.) Report for the HWMA/RCRA Post-Closure Permit for the INTEC Waste Calcining Facility at the INL Site}

\section{INTRODUCTION}

The Waste Calcining Facility (WCF) was closed to a landfill standard pursuant to Hazardous Waste Management Act/Resource Conservation and Recovery Act (HWMA/RCRA) requirements in 1998 and is entombed under a concrete cap. The facility is located within the Idaho Nuclear Technology and Engineering Center (INTEC) at the Idaho National Laboratory (INL) Site. A HWMA/RCRA post-closure permit for the WCF was issued by the Idaho Department of Environmental Quality (DEQ) on September 15, 2003, with an effective date of October 16, 2003. This permit establishes requirements for groundwater characterization and monitoring, maintenance, and inspection procedures for the WCF to ensure continued protection of human health and the environment. The post-closure permit also includes semiannual reporting requirements under Permit Conditions III.H. and I.U. These reporting requirements have been combined into this single semiannual report, due to DEQ in January 2007, as agreed between the Idaho Cleanup Project (ICP) (previously called the Idaho National Engineering and Environmental Laboratory) and DEQ (Mascareñas January 6, 2004; Bullock February 12, 2004).

\subsection{Purpose and Scope}

The purpose of this semiannual report is to satisfy the requirements of both Permit Conditions III.H. and I.U. of the WCF post-closure permit for the period April 16, 2006, to October 16, 2006. Permit Condition III.H. and its subsections require the following:

III.H. While in Detection or Compliance Monitoring Program(s), the permittee shall submit semi-annual reports to the Director that shall include, at a minimum:

III.H.1. A narrative summary of ground water monitoring data which has been collected to date, and a detailed listing of the monitoring and analytical data obtained not included in the previous report, including laboratory QA/QC information and all newly identified compounds from the annual Appendix IX testing;

III.H.2. Analytical results from sampling and analysis, and a narrative summary of sampling data including laboratory QA/QC information;

III.H.3. A table summary of the ground water elevation and well depth data collected in accordance with Permit Condition III.E, the results of ground water flow rate and direction calculations, and parameters used to calculate ground water flow velocities and direction for the perched aquifer in accordance with Permit Condition III.B shall be submitted annually, including a summary/statement that either:

III.H.3.a. The monitoring network as described in this permit is still valid for the purpose of satisfying the requirements of IDAPA 58.01.05.008 (40 CFR §264.97(a)); or 
III.H.3.b. An in-depth evaluation of the monitoring network is warranted and a proposal, including a schedule, for such will be submitted to the Director within ten (10) calendar days of the submittal of this summary.

III.H.4. Field sampling data, including:

- $\quad$ Sample collection procedures

- Amount of purge water collected at each well

- $\quad$ Sample preservation methods

- Chain of custody information

- $\quad$ Any anomalies that may have occurred during sampling and analysis.

III.H.5. A summary of maintenance work done on ground water monitoring equipment; and

III.H.6. A summary of deficiencies identified during the inspections of the monitoring wells, surveyed benchmarks, and WCF cap (see Permit Condition IV.B).

Sections 2 through 6 of this report contain the required information for the Permit Condition III.H. semiannual report. Annual information required by Permit Condition III.H.3. is included in this semiannual report, consistent with Permit Condition III.E.2., which requires "the permittee shall measure monitoring well depths annually and report results in the fall semiannual report. Total depths are not required for monitoring wells with dedicated downhole equipment (e.g., pump) that interferes with the ability to measure the total depth. Total well depth for wells with dedicated downhole equipment shall be determined whenever the dedicated equipment is removed (but is not required on more than an annual frequency."

Permit Condition I.U. requires the following:

I.U. The permittee shall report all other instances of noncompliance not otherwise required to be reported, in accordance with Permit Condition I.R. and I.T. of this permit, on a semiannual basis from the effective date of the permit. The reports shall contain the information, as applicable, listed in Permit Condition I.T. of this permit. Reporting shall not constitute a defense for any noncompliance.

Section 7 contains the required information for the Permit Condition I.U. report for the April 16, 2006, to October 16, 2006, reporting period.

\subsection{Background}

Shallow perched groundwater beneath the WCF cap is routinely monitored through a detection monitoring program as outlined in the RCRA post-closure permit. The WCF monitoring well network originally consisted of 11 wells in the vicinity of the WCF cap (Figure 1-1). All 11 wells were monitored bimonthly for water levels; groundwater samples for laboratory analysis were required to be collected from five of these monitoring wells (MW-2, MW-5-2, MW-12-2, MW-18-2, and CPP-33-1). 


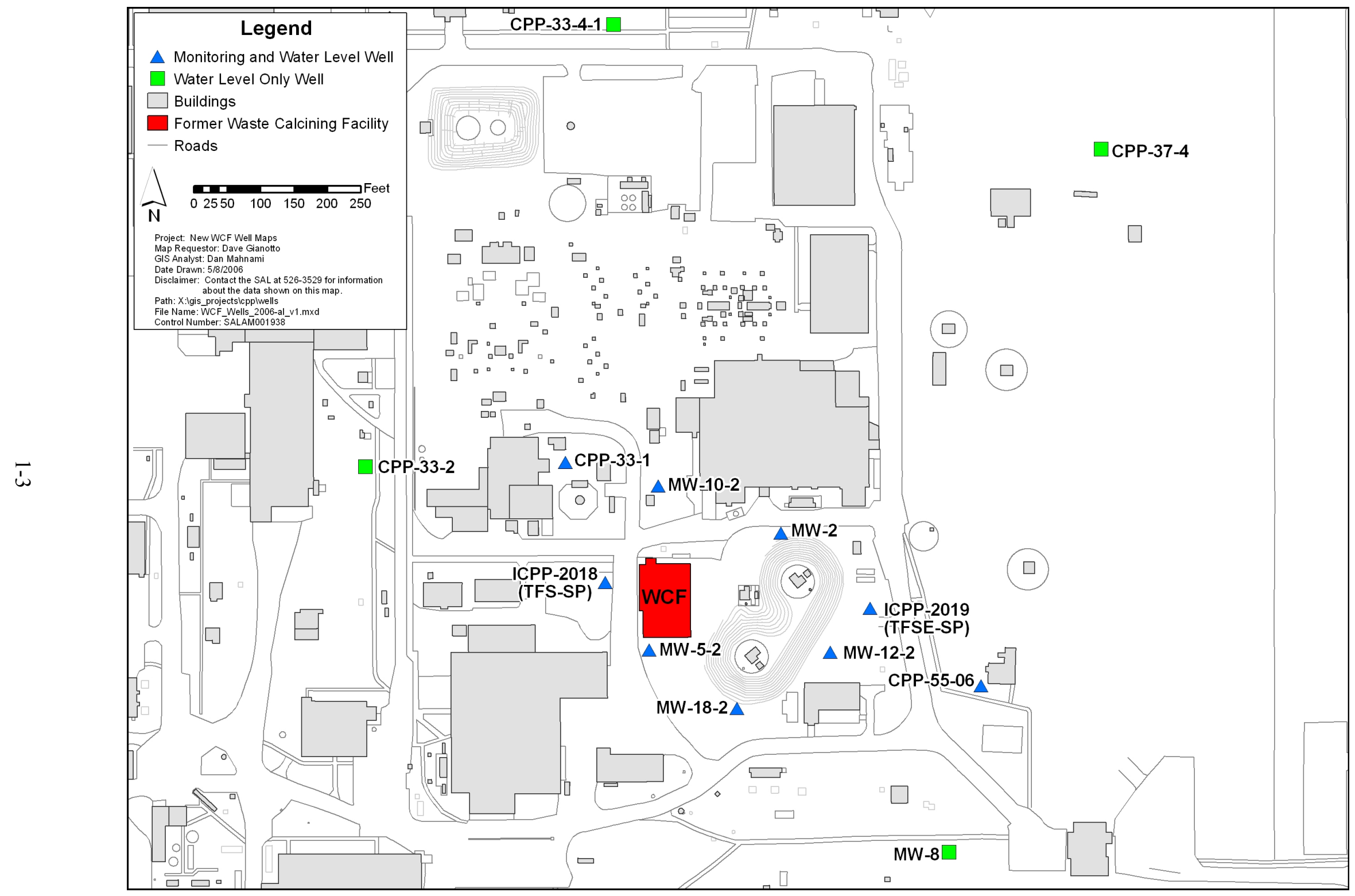

Figure 1-1. Groundwater monitoring network for WCF. 
As required by Permit Condition III.H.3.a., a Monitoring Well Network Compliance Statement was provided in the fall 2004 semiannual report (DOE-NE-ID 2005a). The compliance statement assessed whether the monitoring network as described in the WCF post-closure permit has satisfied the requirements of IDAPA 58.01.05.008 (40 CFR 264.97(a)). Because monitoring wells MW-12-2, MW-18-2, and CPP-33-1 had not consistently yielded a sufficient volume of water for sampling, the compliance statement proposed evaluating the monitoring network by adding MW-10-2 and CPP-55-06 for quarterly sampling to provide supplemental information.

As required by Permit Condition III.I.2., the construction of two additional monitoring wells was completed on April 5, 2005. The two wells, identified as ICPP-2018 (alias TFS-SP for tank farm south-shallow perched) and ICPP-2019 (alias TFSE-SP for tank farm southeast-shallow perched), were first sampled during the May 10-12, 2005, sampling event.

A RCRA Class 2 permit modification request (PMR) to modify the WCF monitoring well network, approved by DEQ on January 17, 2006, revised the permit to add wells ICPP-2018, ICPP-2019, and MW-10-2 as monitoring wells, change well CPP-55-06 from a water elevation well to a monitoring well, remove well MW-4-2 as a water elevation well, and change groundwater sampling and analysis procedures and monitoring schedule.

In previous semiannual reports, sample results from wells CPP-55-06 and MW-10-2 were reported as supplemental wells as proposed in the response to the Comprehensive Ground Water Monitoring Evaluation (CME) for the Waste Calcine Facility (WCF) (Mascareñas December 9, 2004). As a result of the RCRA Class 2 PMR to modify the WCF monitoring well network, approved by DEQ on January 17, 2006, wells CPP-55-06 and MW-10-2 are no longer considered as supplemental wells but are now considered to be part of the permit monitoring network and were considered monitoring wells, not supplemental wells during the January-February, May, and July-August 2006 sampling events. (Monson January 17, 2006)

The addition of these wells provides a total of 13 wells in the WCF monitoring network, three of which are background wells and six are point-of-compliance wells. Even if two of the point-of-compliance wells (MW-12-2 and MW-18-2) continue to be dry, the current WCF monitoring network is expected to continue to satisfy the requirements of IDAPA 58.01.05.008 (40 CFR 264.97(a)).

Twelve quarterly groundwater sampling events have been conducted since the October 16, 2003, effective date of the post-closure permit:

- $\quad$ November 10, 2003, and February 4, 2004 (DOE-NE-ID 2004)

- $\quad$ May 10-12, 2004, and August 2-4, 2004 (DOE-NE-ID 2005a)

- $\quad$ November 1-2, 2004, and February 1-3, 2005 (DOE-NE-ID 2005b)

- $\quad$ May 3-11, 2005, and August 8-11, 2005 (DOE-ID 2006a)

- $\quad$ October 31-November 2, 2005, and January 30-February 1, 2006 (DOE-ID 2006b)

- $\quad$ May 1-4, 2006 (Medema August 30, 2006) and July 31-August 2, 2006 (Medema November 17, 2006).

Statistical analyses of all data collected to date are ongoing to establish background concentrations pursuant to Permit Condition III.D.1 and will be submitted to DEQ for the director's approval. 


\section{FIELD METHODS}

This section describes the sample collection procedures for the May 2006 and July-August 2006 quarterly sampling of the WCF groundwater monitoring network, volumes of purge water generated during sampling, sample preservation methods, chain-of-custody (COC) information, and anomalies or deviations from the normal field methods.

\subsection{Sample Collection Procedures}

Prior to groundwater sampling, the overall condition of each well is visually inspected and the depth to groundwater measured using an electronic water level indicator. All perched water wells to be sampled are purged prior to sample collection. Typically, three to five times the calculated casing volume of water in the well is removed in an effort to obtain a representative sample. During purging, specific conductance, $\mathrm{pH}$, and temperature are measured. Stabilization of the parameters is satisfied when successive readings meet the following criteria:

- $\quad \mathrm{pH} \pm 0.1$ standard units

- $\quad$ Specific conductance $\pm 10 \mu \mathrm{mhos} / \mathrm{cm}$

- $\quad$ Temperature $\pm 0.5^{\circ} \mathrm{C}$.

When purging a well, if insufficient water is available to complete the purging, the well is allowed to recover overnight and then sampled the next working day. If the well volume is still insufficient to complete purging, the available water is collected for analysis. Sampling at the well is then considered complete. The first sample is used for determining $\mathrm{pH}$, specific conductance, and temperature. The following is the preferred order for sample collection:

1. Metals (filtered)

2. Volatile organic compounds (VOCs)

3. Semivolatile organic compounds (SVOCs).

The sampler protects sample bottles from contamination by using clean, waterproof gloves. The identification label is placed on the bottle with the appropriate information, such as sample ID number, name of project area/well, type of analysis, date, sampler, preservative, and collection time. Sufficient water, if available, is collected from the well to fill the required number of bottles. The water is transferred from the sampling equipment directly to the sample bottle. The bottle is filled to the neck. For samples that require volatile organic analysis, the bottle is filled until no air bubbles or headspace is left.

\subsection{Purge Water}

Table 2-1 shows the amount of purge water generated from the May 1-4, 2006, and the July 31-August 2, 2006, sampling events. Monitoring wells MW-2, CPP-33-1, CPP-55-06, ICPP-2018, and ICPP-2019 yielded sufficient water for sampling both quarterly events. Monitoring wells MW-12-2 and MW-18-2 were dry during both quarterly sampling events. Well MW-10-2 ran dry after repeated sampling attempts, so only a partial data set is available for this well for the May and July-August sampling events. MW-5-2 had sufficient water for the May sampling event, but unexpectedly ran dry during the July-August sampling event, which precluded obtaining a metals sample. 
Table 2-1. Approximate volumes of purge water generated from sampling events.

\begin{tabular}{|c|c|c|}
\hline Monitoring Well & $\begin{array}{l}\text { May } 1-4,2006, \\
\text { Purge Volume }\end{array}$ & $\begin{array}{c}\text { July } 31-\text { Aug. 2, 2006, } \\
\text { Purge Volume }\end{array}$ \\
\hline СРP-33-1 & $0.7 \operatorname{gal}(5 / 1 / 06)$ & $0.5 \operatorname{gal}(7 / 31 / 06)$ \\
\hline MW-2 & $\begin{array}{l}4.2 \text { gal }(5 / 2 / 06) \\
4.2 \text { gal }(5 / 2 / 06)-\text { SVOC resample }\end{array}$ & $4.0 \mathrm{gal}(8 / 1 / 06)$ \\
\hline MW-5-2 & $4.5 \operatorname{gal}(5 / 2 / 06)$ & $3.5 \operatorname{gal}(8 / 1 / 06)$ \\
\hline MW-12-2 & Dry $(5 / 2 / 06)$ & Dry $(8 / 1 / 06)$ \\
\hline MW-18-2 & Dry $(5 / 2 / 06)$ & Dry $(8 / 1 / 06)$ \\
\hline MW-10-2 & $2.3 \mathrm{gal}(5 / 3 / 06)$ & $4.0 \operatorname{gal}(7 / 31 / 06)$ \\
\hline CPP-55-06 & 5.0 gal $(5 / 1 / 06)$ & $5.2 \operatorname{gal}(7 / 31 / 06)$ \\
\hline ICPP-2018 & $6.2 \mathrm{gal}(5 / 2 / 06)$ & $5.5 \operatorname{gal}(8 / 2 / 06)$ \\
\hline ICPP-2019 & $\begin{array}{l}8.3 \text { gal }(5 / 2 / 06) \\
8.0 \text { gal }(5 / 4 / 06)-\text { SVOC resample }\end{array}$ & 8.0 gal $(8 / 2 / 06)$ \\
\hline
\end{tabular}

\subsection{Sample Preservation Methods}

Samples are preserved to minimize any chemical or physical changes that might occur between the time of sample collection and analysis. Preservation can be by physical means (e.g., kept at a certain temperature) or chemical means (e.g., with the addition of chemical preservatives). If a sample is not preserved properly, the levels of constituents of concern in the sample may be altered through chemical, biological, or photo-degradation or by leaching, sorption, or other chemical or physical reactions within the sample container. Applicable preservation requirements followed for these sampling activities, container types, and sample holding times are identified in Table 2-2.

Table 2-2. Summary of sample preservation methods.

\begin{tabular}{|c|c|c|c|}
\hline Analysis & Container Type & Holding Time & Preservative \\
\hline $\begin{array}{l}\text { Metals (filtered; SW } 846 \text { methods 6010B, } \\
\text { 200.9, 7470A, and CLP ILM040-EPA 335.2) }\end{array}$ & Plastic & 180 days & $\begin{array}{l}\mathrm{HNO}_{3} \\
\mathrm{pH}<2\end{array}$ \\
\hline $\begin{array}{l}\text { VOCs (SW-846 Method 8260B) } \\
\text { Isobutyl alcohol (SW-846 Method 8015B) }\end{array}$ & Glass vials & 14 days & $\begin{array}{l}\mathrm{H}_{2} \mathrm{SO}_{4}, \mathrm{pH}<2 \\
\text { cool to } 4^{\circ} \mathrm{C}\end{array}$ \\
\hline $\begin{array}{l}\text { SVOCs (SW-846 Method 8270) 1,4-Dioxane } \\
\text { (SW-846 Method 8270C) }\end{array}$ & Amber glass & $\begin{array}{l}7 / 40 \text { days } \\
\text { extraction/analysis }\end{array}$ & Cool to $4^{\circ} \mathrm{C}$ \\
\hline Hydrazine (ASTM 1385) & Plastic & $\begin{array}{l}\text { Analyze as soon as } \\
\text { possible }\end{array}$ & None \\
\hline Cyanide (SW-846, Method 9010) & Plastic & $\begin{array}{l}\text { Analyze as soon as } \\
\text { possible }\end{array}$ & $\begin{array}{l}50 \% \mathrm{NaOH} \text { to } \\
\mathrm{pH}>12, \text { cool to } \\
4^{\circ} \mathrm{C}\end{array}$ \\
\hline Formaldehyde (SW-846 Method 8315A) & Amber glass & $\begin{array}{l}3 \text { days to } \\
\text { extraction; } 3 \text { days } \\
\text { to analysis }\end{array}$ & Cool to $4^{\circ} \mathrm{C}$ \\
\hline Gamma screen & $\begin{array}{l}\text { High-density } \\
\text { polyethylene or } \\
\text { lab-supplied }\end{array}$ & 30 days & No preservative \\
\hline
\end{tabular}




\subsection{Chain of Custody}

COC procedures begin immediately after collection of the first sample. After sample collection, the sampling team initiates COC forms to track the samples. All samples remain in custody of the sampling team until the custody is transferred to the analytical laboratory sample custodian. Upon receipt of samples at the laboratory, the sample custodian reviews the sample labels and the COC form to ensure completeness and accuracy. If discrepancies are noted during this review, immediate corrective action is sought with the sampling team member(s) identified on the COC relinquishing custody. Pending successful corrective action, the laboratory sample custodian signs and dates the COC signifying acceptance of delivery and custody of the samples. Copies of all COC forms for the May 1-4 and the July 31-August 2, 2006, sampling events are included Appendix A.

\subsection{Anomalies}

The Field Sample Logbook indicates that TFSE-SP (ICPP-2019) was re-sampled on May 4, 2006, because the semivolatile (SVOC) sample arrived broken at the analytical laboratory Southwest Research Institute (SWRI). Well MW-2 was also re-sampled on May 4, 2006, because the SVOC sample bottle was broken in transit to the analytical laboratory.

A validated, unqualified result of $600 \mu \mathrm{g} / \mathrm{L}$ toluene was detected at well MW-10-2 during the October-November 2005 sampling event (sample number WCF12201VA). As a follow-up to this elevated toluene level, ICP proposed obtaining duplicate VOC samples from this well during the WCF 10th quarterly sampling event (Hutten January 11, 2006, and Safford February 23, 2006).

Well MW-10-2 had not consistently had enough water for the full suite of WCF analytes, and the preferred order of sample collection listed in the WCF permit indicates that when sample water is known to be limited, metals are to be sampled before VOCs. Thus, to be sure sufficient water existed for duplicate VOC analyses from this well, ICP requested concurrence from DEQ to change the preferred order of sampling for well MW-10-2 only during the 10th quarterly sampling event so that the VOC and the VOC duplicate would be sampled first. DEQ approved this revised sampling order for MW-10-2 for the 10th quarterly sampling event (English January 12, 2006).

Duplicate volatile organic samples were taken from well MW-10-2 on January 31, 2006. Validated, unqualified results of $92 \mu \mathrm{g} / \mathrm{L}$ and $95 \mu \mathrm{g} / \mathrm{L}$ toluene were detected in the sample and the duplicate sample, respectively. These results, reported in the spring 2006 semiannual report (DOE-ID 2006b), represent a significant reduction from the $600-\mu \mathrm{g} / \mathrm{L}$ toluene result detected at well MW-10-2 in November 2005.

In the March 29, 2006, ICP letter notifying DEQ of 10th quarterly WCF quality assurance/quality control (QA/QC) issues, ICP suggested again obtaining duplicate VOC samples from well MW-10-2 during the WCF 11th quarterly sampling event in an effort to learn more about the elevated toluene result at this well (McNeel March 29, 2006). This plan was similar to the plan that was presented to DEQ for the 10th quarterly sampling event for which concurrence was obtained on January 12, 2006 (English January 12, 2006). DEQ provided concurrence on April 7, 2006 (Bullock April 7, 2006) for this alternate sampling plan for the 11 th quarterly sampling event. The 11th quarterly sampling event occurred during May 1-4, 2006, and the alternate sampling order for MW-10-2 was performed.

Sample WCF14901VA and Sample WCF14902VA (duplicate) taken from well MW-10-2 during the May 1-4, 2006 (11th quarterly) sampling event had 5.4 and $6.4 \mu \mathrm{g} / \mathrm{L}$ toluene, respectively. These results represent a continuation of the significant reduction from the $600 \mu \mathrm{g} / \mathrm{L}$ toluene result detected at well MW-10-2 in November 2005 and are far below the groundwater protection standard of 2,000 $\mu \mathrm{g} / \mathrm{L}$. 
During the 11th quarterly sampling event, iodomethane and 1,1,1-trichloroethane results in four samples (from wells MW 5-2, CPP-33-1, MW-2, and ICPP 2018) were qualified with a "UJ" validation flag. These results were nondetected and the sample quantitation limit is an estimated quantity because the initial calibration (ICAL) percent relative standard deviation (\%RSD) was greater than $15 \%$ but less than $90 \%$. The $\%$ RSD $>15 \%$ was not a failure on the laboratory's part as several options are allowed for acceptance of the initial calibration. One of those options is to determine that the average of all \%RSD values meets the $15 \%$ criteria for the $8260 \mathrm{~B}$ method, which the ICAL did with $9.1 \%$. SW-846 Method 8000B states that the analyst and the data user must be aware that the use of this approach will lead to greater uncertainty for those analytes for which the RSD is greater than $15 \%$. The analyst and the data user should review the associated QC results carefully, with particular attention to the matrix spike and laboratory control sample results, to determine if the calibration linearity poses a significant concern. In this case, the UJ flag was an indicator for the data user to further evaluate the data.

The ICP Sample and Analysis Management (SAM) office evaluated all the laboratory control sample (LCS) and matrix spike/matrix spike duplicate (MS/MSD) percent recoveries and MS/MSD relative percent differences (RPDs) and all were within acceptance limits. Based on that additional evaluation, no significant concern existed based on the linearity of the initial calibration used for the iodomethane and 1,1,1-trichloroethane qualified results. This situation and the associated follow-up actions are similar to the WCF 7th quarterly results for iodomethane and methylene chloride that were discussed in a meeting with DEQ staff on July 14, 2005, and did not require notification by letter. ICP considers this issue resolved.

The QA/QC anomalies numbered 1 through 3 below occurred during sampling and analysis associated with the 11th quarterly (May 1-4, 2006), and, following these, anomalies 1 and 2 below occurred during the 12th quarterly (July 31-August 2, 2006) sampling events. These anomalies were previously reported as required by post-closure permit condition III.D.5 (McNeel August 7, 2006 and $\mathrm{McNeel}$ October 18, 2006). Corrective actions for these data issues were identified in the 11th and 12th quarterly data summaries (Medema August 30, 2006, and Medema November 17, 2006).

The following issues were discussed in the August 7, 2006, letter:

1. The laboratory control sample/laboratory control sample duplicate (LCS/LCSD) had percent recoveries below the QC criterion for pyridine in the LCS and recoveries less than $10 \%$ for pyridine and aniline in the LCSD. In addition, the relative percent difference (RPD) was outside of QC criterion for pyridine, aniline, and phenol. The nondetected results for pyridine and aniline were rejected " $R$ " in all samples. No validation action was taken on the phenol results because the LCS/LCSD recoveries for this constituent met QC limits.

Discussion: The LCS/LCSD percent recovery issue was, at the time, suspected to be due to solvent contamination in the laboratory. A method blank was extracted along with the samples and it contained significant peaks in the region of elution of the target compounds. There was contamination traced back to the lot number of the methylene chloride used for the extraction of the field and QC samples. Initial communications of these difficulties were sent by SWRI to the ICP SAM office on June 6, 2006. In addition to the co-extracted interferences in sample WCF14601V9 from well TFS-SP (ICPP-2018), discussed below, which may have impacted spiked compound recoveries, the interferences from the methylene chloride used for extraction may have also contributed to the lower recoveries. This could explain the low and inconsistent recoveries seen in the LCS/LCSD samples. 
Corrective Action: The analytical laboratory was directed to provide the ICP SAM office proof of contaminant-free extraction and acceptable recoveries for these analytes before the next round of sampling.

2. The percent recoveries of pyridine and aniline were zero for the MS/MSD performed on sample WCF14601V9 from well ICPP-2018. In addition, RPD was outside of the QC criterion for pyridine and aniline. The nondetected results for pyridine and aniline in sample WCF14601V9 were rejected "R."

Discussion: Internal standards met area and retention time criteria as per the method for all samples with the exception of perylene-d12 in samples WCF14601V9 (from well ICPP-2018) and the associated MS/MSD set as well as sample WCF14101V9 (from well MW-5-2). Large unresolved organic complexes were present in both samples mentioned and they may have interfered with the area response of the internal standard. As the MS/MSD set shows the same phenomenon and is essentially extraction and analysis of the same sample, the failing area response may be attributed to matrix interferences. Internal standard perylene-d12 does not quantify any target or surrogate compound of interest; therefore, its impact to data quality is minimal.

Corrective Action: The ICP SAM office continued to monitor pyridine and aniline, as well as phenol, results, which appear to be affected by matrix interference on a recurring basis. As discussed in previous WCF data summaries, the matrix interference is believed to be caused by an unknown suspected hydrocarbon that is possibly a degraded or weathered petrochemical. On a project under the ICP but outside of the WCF monitoring project scope, analyses are being performed in an investigation to try to identify the unknown hydrocarbon. The analyses from the other project can be correlated with the WCF monitoring analyses through the ICP SAM office in an attempt to identify the suspected interference.

3. The internal standard area counts for five 1,4-dioxane samples were outside specified limits (internal standard area counts were $<50 \%$ but $>25 \%$ ). Nondetect results for 1,4-dioxane in samples WCF14101SV, WCF14401SV, WCF14501SV, and WCF14801SV were qualified as undetected estimated quantities "UJ" for an internal standard area count $<50 \%$ but $>25 \%$. The detected result for 1,4-dioxane in sample WCF14901SV was qualified as an estimated quantity "J" for an internal standard area count $<50 \%$ but $>25 \%$.

Discussion: Isotope-dilution gas chromatography-mass spectrometry (GC-MS) methodology was used for the analysis of 1,4-dioxane. This method allows for the quantification of 1,4-dioxane against its isotope-labeled analogue 1,4-dioxane-d8 as well as for the correction of analyte recovery during sample preparation and analysis. Using isotope-dilution mass spectrometric analysis, the isotope-labeled internal standards can significantly reduce systematic error (bias) from several sources, including sample stability prior to analysis, analyte loss during both the extraction procedure, and post-extraction sample workup, and from the calibration procedure.

Corrective Action: Calibration standards of 1,4-dioxane at 5.0, 10, 20, 40, and $50 \mathrm{ng} / \mu \mathrm{L}$ were analyzed. The 1,4-dioxane was fixed at a concentration of $50 \mathrm{ng} / \mu \mathrm{L}$ in all calibration standards (as per standard isotope dilution methodology). The 1,4-dioxane-d8 serves a dual purpose in the analysis: (1) a surrogate compound to monitor extraction efficiency and (2) an internal standard to quantify the native 1,4-dioxane with an automatic correction for extraction losses. Internal standard 1,4-dioxane-d8 is a compound spiked into the samples at the time of extraction and its recovery is more relevant to the data than recovery standard 1,4-dichlorobenzene-d4. No corrective action was required if the area count fell below $50 \%$ of the day's mid-level standard. 
The analytical laboratory used advisory limits of 50-150\%. Recoveries of 1,4-dioxane-d8 were above $50 \%$ in most samples. The impact to data quality was minimal to none as the benefit of utilizing isotope dilution methodology is having accurate quantitation despite losses that may have been encountered during the extraction process. Therefore, no corrective action was deemed necessary.

A letter dated October 18, 2006, from Kliss McNeel, ICP, to Brian R. Monson, DEQ, discussed field sampling problems and laboratory QA/QC problems that were identified from the analysis of the groundwater monitoring network samples for the July 31-August 2, 2006, sampling event.

The nondetect results for tetrachloroethene were qualified as undetected estimated quantities "UJ" for a $\% \mathrm{RSD}>15 \%$ in the associated initial calibration for samples WCF15601VA, WCF15901VA, WCF16101VA, WCF16201VA, WCF16202VA, WCF16301VA, WCF16501VA, and WCF16601VA. The detected results for tetrachloroethene were qualified as estimated quantities "J" for a $\% \mathrm{RSD}>15 \%$ in the associated initial calibration for samples WCF16401VA and WCF16402VA. The nondetect result for 2-butanone (methyl ethyl ketone) was qualified as an undetected estimated quantity "UJ" for a \%RSD $>15 \%$ in the associated initial calibration WCF16001VA.

The \%RSD $>15 \%$ was not a failure on the laboratory's part as several options are allowed for acceptance of the initial calibration. One of those options is that the average of all \%RSD values meets the $15 \%$ criteria for the $8260 \mathrm{~B}$ method, which the ICALs did on August 7, 2006, with $8.4 \%$ and August 11, 2006, with 7.4\%. SW-846 Method 8000B states that the analyst and the data user must be aware that the use of this approach will lead to greater uncertainty for those analytes for which the RSD is greater than $15 \%$. The analyst and the data user should review the associated QC results carefully, with particular attention to the matrix spike and laboratory control sample results, to determine if the calibration linearity poses a significant concern. In these cases the $\mathrm{J}$ and $\mathrm{UJ}$ flags were indicators for the data user to further evaluate the data.

The ICP SAM office evaluated all of the LCS and MS/MSD percent recoveries and MS/MSD RPDs and all were within acceptance limits. Based on that additional evaluation, no significant concern existed based on the linearity of the initial calibration used for the tetrachloroethene and 2-butanone qualified results. This situation and the associated follow-up actions are similar to the WCF 7th quarterly results for iodomethane and methylene chloride that were discussed in a meeting with DEQ staff on July 14,2005 , and did not require notification by letter. ICP considers this issue resolved.

The following issues were discussed in the October 18, 2006, letter:

1. An internal standard area count for five 1,4-dioxane samples was outside specified limits (internal standard area counts were $<50 \%$ but $>25 \%$ ). Nondetect results for 1,4-dioxane in samples WCF15601SV, WCF15901SV, WCF16201SV, and WCF16501SV were qualified as undetected estimated quantities "UJ" for an internal standard area count $<50 \%$ but $>25 \%$. The detected result for 1,4-dioxane in sample WCF16301SV was qualified as an estimated quantity "J" for an internal standard area count $<50 \%$ but $>25 \%$.

Discussion: Isotope-dilution GC-MS methodology was used for the analysis of 1,4-dioxane. This method allows for the quantification of 1,4-dioxane against its isotope-labeled analogue 1,4-dioxane-d8 as well as for the correction of analyte recovery during sample preparation and analysis. Using isotope-dilution mass spectrometric analysis, the isotope-labeled internal standards can significantly reduce systematic error (bias) from several sources, including sample stability prior to analysis, analyte loss during both the extraction procedure, and post-extraction sample workup, and from the calibration procedure. 
Corrective Action: Calibration standards of 1,4-dioxane at 5.0, 10, 20, 40, and $50 \mathrm{ng} / \mu \mathrm{L}$ were analyzed. The 1,4-dioxane-d 8 was fixed at a concentration of $50 \mathrm{ng} / \mu \mathrm{L}$ in all calibration standards (as per standard isotope dilution methodology). The 1,4-dioxane-d8 serves a dual purpose in the analysis: (1) a surrogate compound to monitor extraction efficiency and (2) an internal standard to quantify the native 1,4-dioxane with an automatic correction for extraction losses. Internal standard 1,4-dioxane-d8 is a compound spiked into the samples at the time of extraction and its recovery is more relevant to the data than recovery standard 1,4-dichlorobenzene-d4. No corrective action was required if the area count fell below $50 \%$ of the day's mid-level standard.

The analytical laboratory used advisory limits of 50-150\%. Recoveries of 1,4-dioxane-d 8 were above $50 \%$ in most samples. The impact to data quality was minimal to none as the benefit of utilizing isotope dilution methodology is having accurate quantitation despite losses that may have been encountered during the extraction process. Therefore, no corrective action was deemed necessary.

2. Pyridine and aniline were not recovered in the LCS/LCSD. As more than $50 \%$ of the compounds in the semivolatile sample data group exhibited a LCS \% recovery less than $10 \%$ and all samples were nondetect, the reported results for aniline, pyridine, and phenol were all correctly qualified with "R" validation flags. Additional review by the ICP SAM office indicated that the phenol $\mathrm{LCS} / \mathrm{LCSD} \%$ recovery results were within the QC criteria and the original R flags assigned to phenol results could be removed. The phenol R flags were subsequently removed.

Discussion: This issue is similar to that which occurred with aniline and pyridine during the 11th quarterly sampling event. At that time, the LCS/LCSD percent recovery issue was believed to be due to solvent contamination in the laboratory. A method blank was extracted along with the samples and it contained significant peaks in the region of elution of the target compounds. The contamination was traced back to the lot number of the methylene chloride used for the extraction of the field and QC samples.

Corrective Action: The corrective action discussed in the 11 th quarterly data summary stated that the analytical laboratory will provide the ICP SAM office proof of contaminant-free extraction and acceptable recoveries for these analytes before the next round of sampling. After additional investigation into the 11 th quarterly results and the 12 th quarterly results, currently no evidence supports the theory that the low (and zero) LCS/LCSD recoveries are caused by interference due to methylene chloride contamination used for extraction. The lab did not provide the SAM office with proof of contaminant-free extraction and acceptable recoveries for these analytes as was previously discussed because there was no evidence to support that theory. This issue is being thoroughly investigated at the analytical laboratory and the SAM office and has elevated up to the director level at the laboratory. Additional chemists, technical leads, and supervisors are looking at the whole process from beginning to end to work towards solving the problem.

The ICP SAM office continues to monitor pyridine, aniline, and phenol results that appear to be affected by matrix interference on a recurring basis. The unknown suspected hydrocarbon that affected MS/MSD and LCS/LCSD recoveries and that was believed to be a degraded or weathered petrochemical as discussed in previous WCF data summaries was determined to be a weathered diesel range organic. 


\section{LABORATORY RESULTS}

This section includes a narrative summary of groundwater monitoring data that have been collected during the 11th and 12th quarterly sampling events. Comparisons of analytical results with the groundwater protection standards (GPSs) (Table 3-1) are not required by permit while background concentrations are being established. However, the unqualified analytical results were compared to the constituent analyte list and associated GPS identified in Table 3-1 (Module III) of the HWMA/RCRA WCF post-closure permit in this report as a preliminary overview. Results appear in Appendix B.

Table 3-1. Constituent analyte list and associated estimated quantitation limits (EQLs) and groundwater protection standards (GPSs) (DEQ 2004).

\begin{tabular}{|l|c|c|}
\hline \multicolumn{1}{|c|}{ Constituent } & $\begin{array}{c}\text { EQL } \\
(\mu \mathrm{g} / \mathrm{L})\end{array}$ & $\begin{array}{c}\text { GPS } \\
(\mu \mathrm{g} / \mathrm{L})\end{array}$ \\
\hline Arsenic & 5 & 20 \\
\hline Barium & 20 & 4,000 \\
\hline Cadmium & 1 & 10 \\
\hline Chromium & 10 & 200 \\
\hline Lead & 3 & 30 \\
\hline Mercury & 0.2 & 4 \\
\hline Selenium & 20 & 100 \\
\hline Silver & 10 & 200 \\
\hline Vanadium & 20 & 5,200 \\
\hline $1,1,1$-trichloroethane & 1 & 400 \\
\hline $1,1,2$-trichloroethane & 1 & 10 \\
\hline Carbon tetrachloride & 1 & 10 \\
\hline Trichloroethene & 1 & 10 \\
\hline Tetrachloroethene & 1 & 10 \\
\hline Carbon disulfide & 1 & 2,000 \\
\hline Toluene & 1 & 2,000 \\
\hline Pyridine & 5 & 720 \\
\hline
\end{tabular}

\begin{tabular}{|l|r|r|}
\hline \multicolumn{1}{|c|}{ Constituent } & $\begin{array}{c}\text { EQL } \\
(\mu \mathrm{g} / \mathrm{L})\end{array}$ & $\begin{array}{c}\text { GPS } \\
(\mu \mathrm{g} / \mathrm{L})\end{array}$ \\
\hline Isobutyl alcohol & 50 & 36,000 \\
\hline Methyl ethyl ketone & 5 & 38,000 \\
\hline Aniline & 5 & 240 \\
\hline Benzene & 1 & 10 \\
\hline Chloroform & 1 & 200 \\
\hline Methylene chloride & 1 & 86 \\
\hline 1,4-dioxane & 54 & 122 \\
\hline Methyl iodide & 5 & 100 \\
\hline Phenol & 5 & 220,000 \\
\hline Bromoform & 1 & 200 \\
\hline Vinyl chloride & 2 & 4 \\
\hline Trans-1,2-dichloroethylene & 5 & 200 \\
\hline Cis-1,2-dichloroethylene & 5 & 140 \\
\hline Cyanide & 10 & 400 \\
\hline Formaldehyde & 232 & 110,000 \\
\hline Hydrazine & 5 & 0.44 \\
\hline
\end{tabular}

\subsection{Groundwater Monitoring Data}

During the 11th quarterly sampling event, May 1-4, 2006, analytical results were obtained from monitoring wells MW-2, MW-5-2, MW-10-2, CPP-33-1, CPP-55-06, ICPP-2018, and ICPP-2019. Monitoring wells MW-12-2 and MW-18-2 were dry during the 11th quarterly sampling event; therefore, no samples were obtained from these wells in May 2006.

During the 12th quarterly sampling event, July 31-August 2, 2006, analytical results were obtained from monitoring wells MW-2, MW-5-2, MW-10-2, CPP-33-1, CPP-55-06, ICPP-2018, and ICPP-2019. Monitoring wells MW-12-2 and MW-18-2 were dry during the 12th quarterly sampling event; therefore, no samples were obtained from these wells in July-August 2006. 
Groundwater samples were analyzed for the constituent analyte list in Table 3 of the WCF post-closure permit. Results for constituents that were detected at or above the permit-required EQL are discussed below.

\section{Barium}

Validated unqualified detections of barium in the WCF monitoring wells during the May 1-May 4, 2006, ("May") and the July 31-August 2, 2006, ("August") sampling events are shown in Table 3-2. These results were all below the barium GPS of 4,000 $\mu \mathrm{g} / \mathrm{L}$.

\section{Chromium}

Validated unqualified detections of $14.0 \mu \mathrm{g} / \mathrm{L}$ and $10.0 \mu \mathrm{g} / \mathrm{L}$ chromium were reported for well CPP-33-1 for the May and August sampling events, respectively. These results were all below the chromium GPS of $200 \mu \mathrm{g} / \mathrm{L}$.

\section{Tetrachloroethene}

Validated unqualified results of $2.8 \mu \mathrm{g} / \mathrm{L}$ and $3.3 \mu \mathrm{g} / \mathrm{L}$ tetrachloroethene were reported for well MW-10-2 during May and August, respectively. These results were below the tetrachloroethene GPS of $10 \mu \mathrm{g} / \mathrm{L}$.

\section{Toluene}

Validated unqualified results of $5.4 \mu \mathrm{g} / \mathrm{L}$ and $17 \mu \mathrm{g} / \mathrm{L}$ toluene were reported for well MW-10-2 during May and August, respectively. These results were below the toluene GPS of 2,000 $\mu \mathrm{g} / \mathrm{L}$.

Table 3-2. Validated unqualified barium results in WCF wells in May 2006 and August $2006(\mu \mathrm{g} / \mathrm{L})$.

\begin{tabular}{|c|c|c|c|c|c|c|c|}
\hline Month & MW-5-2 & MW-2 & CPP-33-1 & ICPP-2018 & ICPP-2019 & СРP-55-06 & MW-10-2 \\
\hline May & 604 & 299 & 154 & 382 & 200 & 182 & $\mathrm{NS}^{\mathrm{a}}$ \\
\hline August & $\mathrm{NS}^{\mathrm{a}}$ & 292 & 133 & 388 & 195 & 251 & 249 \\
\hline
\end{tabular}

\subsection{Newly Identified Compounds}

Prior to the January 17, 2006, approval of the Class 2 permit modification request, Permit Condition III.I.3. required that a sample be collected annually from one of the point-of-compliance wells and analyzed for all constituents listed in IDAPA 58.01.05.008 (40 CFR Part 264, Appendix IX) for the first 2 years after permit issuance. This permit condition was satisfied by sampling and analyses performed during the $3 \mathrm{rd}$ and 7 th quarterly sampling events. Any newly identified compounds shall be added to the existing list of analytes in Table 3-1 as part of the Class 3 permit modification following the establishment of the background data. The first year's sampling for Appendix IX constituents occurred in May 2004 and were reported in the fall 2004 semiannual report (DOE-NE-ID 2005a). The second year's sampling for Appendix IX constituents occurred in May 2005 and were reported in the fall 2005 semiannual report (DOE-ID 2006a). 


\section{GROUNDWATER LEVELS, FLOW DIRECTION, AND GRADIENT 4.1 Water Elevation and Well Depth}

dates:

Depths to water in WCF monitoring wells were measured within a 24-hour period on the following

- $\quad$ November 15-16, 2005

- January 16-17, 2006

- $\quad$ March 14-15, 2006

- $\quad$ May 16-17, 2006

- July 19-20, 2006

- $\quad$ September 19-20, 2006.

Total well depths were measured on June 6, 2006, with exceptions noted in Table 4-1 (required annually unless downhole equipment interferes with the ability to obtain measurements). Table 4-1 shows the results of the total well depths measured for the WCF monitoring network during the past year. Table 4-2 shows the field-measured depth to water and water level elevation for each location over the past year.

\subsection{Groundwater Flow Direction and Gradient}

The hydraulic gradient and inferred flow directions for the uppermost (perched) groundwater were calculated using the bimonthly water level measurements. These calculations are presented in Appendix $\mathrm{C}$, along with perched water elevation contour maps and well hydrographs.

With the exception of well CPP-33-1, which is completed at a shallower depth, all of the WCF monitoring wells are screened in the shallow perched zone that generally coincides with the 110-ft sedimentary interbed. This water-bearing zone is defined as perched because it is underlain by unsaturated materials. Perched water tends to flow vertically downward but may also flow laterally where a horizontal hydraulic gradient exists and where low-permeability units are present that impede downward flow. Compared with groundwater flow in the underlying Snake River Plain Aquifer, flow paths in the perched water can be tortuous and difficult to predict.

Water level contour maps (Appendix C) suggest southeasterly flow of the shallow perched water, which is consistent with similar data from 2004 and 2005 (DOE-NE-ID 2005a; DOE-ID 2006a). The inferred flow direction coincides with the southeasterly dip of the top of the 110-ft interbed beneath and south of the tank farm.

The perched water level data for September 19, 2006, (Appendix C) shows a southeasterly hydraulic gradient ranging from 0.010 to $0.023 \mathrm{ft} / \mathrm{ft}$ to the southeast. Assuming a gradient of $0.02 \mathrm{ft} / \mathrm{ft}$, along with reasonable values of hydraulic conductivity and porosity, horizontal shallow perched water flow velocities are predicted to be approximately $0.5 \mathrm{~m} /$ day toward the southeast. Note that this calculation assumes an isotropic, porous medium, and this assumption is not valid for the fractured basalt. Actual flow velocities through joints in the basalt could be considerably faster than the calculated $0.5 \mathrm{~m} /$ day. 
Table 4-1. Shallow perched groundwater well elevations and total depths of monitoring wells.

\begin{tabular}{|c|c|c|c|c|c|c|c|c|c|}
\hline Well Name & $\begin{array}{l}\text { Brass Cap } \\
\text { Elevation }^{\mathrm{a}} \\
(\mathrm{ft} \text { asl })\end{array}$ & $\begin{array}{c}\text { Drilled } \\
\text { Depth } \\
\text { (ft bgs) }\end{array}$ & $\begin{array}{l}\text { Depth to } \\
\text { Screen Top } \\
\text { (ft bgs) }\end{array}$ & $\begin{array}{l}\text { Depth } \\
\text { to Screen } \\
\text { Bottom } \\
\text { (ft bgs) }\end{array}$ & $\begin{array}{c}\text { Stickup } \\
\text { from Brass } \\
\text { Cap to MP } \\
(\mathrm{ft})\end{array}$ & $\begin{array}{c}\text { MP } \\
\text { Elevation } \\
\text { (ft asl) }\end{array}$ & $\begin{array}{c}\text { Elevation } \\
\text { at Screen } \\
\text { Bottom } \\
\text { (ft asl) }\end{array}$ & $\begin{array}{l}\text { Screen } \\
\text { Bottom } \\
\text { from MP } \\
(\mathrm{ft} b \mathrm{bm}) \\
\end{array}$ & $\begin{array}{l}\text { Well Depth } \\
\text { from MP } \\
(\mathrm{ft})\end{array}$ \\
\hline СРP-33-1 & 4914.33 & 113.6 & 89 & 99 & 2.49 & 4916.82 & 4815.33 & 101.49 & $102.56^{\mathrm{b}}$ \\
\hline СРP-33-2 & 4913.29 & 114.8 & 85.8 & 105.8 & 1.82 & 4915.11 & 4807.49 & 107.62 & $107.90^{\mathrm{b}}$ \\
\hline CPP-33-4-1 & 4911.02 & 124 & 98.2 & 118.25 & 2.20 & 4913.22 & 4792.77 & 120.45 & $117.47^{\mathrm{b}}$ \\
\hline СРP-37-4 & 4910.13 & 129.3 & 99.6 & 110 & 1.89 & 4912.02 & 4800.23 & 111.89 & $112.68^{\mathrm{b}}$ \\
\hline СРP-55-06 & 4911.61 & 122.9 & 93.1 & 113.1 & 1.98 & 4913.59 & 4798.51 & 115.08 & $115.32^{\mathrm{b}}$ \\
\hline MW-2 & 4912.3 & 127 & 102 & 112 & 2.54 & 4914.84 & 4800.30 & 114.54 & $113.20^{\mathrm{b}}$ \\
\hline MW-5-2 & 4915.59 & 141 & 106.5 & 126.5 & 2.39 & 4917.98 & 4789.09 & 128.89 & $126.02^{\mathrm{b}}$ \\
\hline MW-8 & 4910.87 & 141 & 115 & 125 & 2.65 & 4913.52 & 4785.87 & 127.65 & 127.99 \\
\hline MW-10-2 & 4913.88 & 181 & 141 & 151 & 2.68 & 4916.56 & 4762.88 & 153.68 & 154.35 \\
\hline MW-12-2 & 4912.14 & 153 & 109 & 119 & 2.98 & 4915.12 & 4793.14 & 121.98 & 122.00 \\
\hline MW-18-2 & 4913.74 & 492 & 113.5 & 123.5 & 2.75 & 4916.49 & 4790.24 & 126.25 & 124.77 \\
\hline ICPP-2018 & 4913.26 & 119 & 97.9 & 117.9 & 2.61 & 4915.87 & 4795.36 & 120.51 & $120.90^{\mathrm{b}}$ \\
\hline ICPP-2019 & 4912.06 & 121.5 & 95.2 & 120.2 & 2.60 & 4914.66 & 4791.86 & 122.80 & $123.20^{\mathrm{b}}$ \\
\hline $\begin{array}{l}\text { a. Elevations } r \\
\text { b. Due to prese } \\
\text { asl = above se } \\
\text { bgs = belowgr } \\
\text { bmp = below } \\
\text { MP = measuri }\end{array}$ & $\begin{array}{l}\text { erenced to NGV } \\
\text { ce of pump and } \\
\text { evel. } \\
\text { ind surface. } \\
\text { easuring point. } \\
\text { point. }\end{array}$ & $\begin{array}{l}9 \text { datum. } \\
\text { water level in }\end{array}$ & Imentation, total & ell depth repor & from measuring & oint measured & 004. & & \\
\hline
\end{tabular}


Table 4-2. Field-measured depth to water and water level elevations. ${ }^{\mathrm{a}}$

\begin{tabular}{|c|c|c|c|c|c|c|}
\hline Well Name & Nov. $15-16,2005$ & Jan. 16-17, 2006 & March 14-15, 2006 & May $16-17,2006$ & July 19-20, 2006 & Sept. 19-20, 2006 \\
\hline \multicolumn{7}{|c|}{$\begin{array}{l}\text { Bimonthly Water Depth Measurements } \\
\text { (ft bmp) }\end{array}$} \\
\hline CPP-33-1 & 101.17 & 101.01 & 100.34 & 100.37 & 100.46 & 100.77 \\
\hline CPP-33-2 & 102.33 & 98.52 & 98.78 & 98.8 & 100.7 & 100.03 \\
\hline CPP-33-4-1 & 98.7 & 98.66 & 98.65 & 98.67 & 98.65 & 98.66 \\
\hline CPP-37-4 & 103.56 & 103.5 & 103.21 & 101.42 & 102.14 & 103.03 \\
\hline CPP-55-06 & 107.9 & 105.1 & 104.79 & 105.27 & 105.82 & 107.69 \\
\hline MW-2 & 109.26 & 106.53 & 106.21 & 106.27 & 107.16 & 108.85 \\
\hline MW-4-2 & 110.7 & 107.58 & 105.34 & 105.3 & 105.51 & 105.96 \\
\hline MW-5-2 & 121.7 & 122.21 & 122.56 & 122.97 & 122.04 & 123.81 \\
\hline MW-8 & Dry & Dry & Dry & Dry & Dry & Dry \\
\hline MW-10-2 & 149.2 & 148.84 & 148.49 & 149.09 & 148.74 & 148.67 \\
\hline MW-12-2 & Dry & Dry & Dry & Dry & Dry & Dry \\
\hline MW-18-2 & Dry & Dry & Dry & Dry & Dry & Dry \\
\hline ICPP-2018 & 109.11 & 109 & 108.07 & 107.7 & 108.69 & 110.03 \\
\hline ICPP-2019 & 109.11 & 106.3 & 105.97 & 106.13 & 106.95 & 108.69 \\
\hline \multicolumn{7}{|c|}{$\begin{array}{l}\text { Bimonthly Perched Water Elevations } \\
(\mathrm{ft} \text { asl })\end{array}$} \\
\hline CPP-33-1 & 4815.65 & 4815.81 & 4816.48 & 4816.46 & 4816.31 & 4816.05 \\
\hline CPP-33-2 & 4812.78 & 4816.6 & 4816.34 & 4816.32 & 4814.41 & 4815.09 \\
\hline СРP-33-4-1 & 4814.52 & 4814.56 & 4814.58 & 4814.55 & 4814.57 & 4814.57 \\
\hline CPP-37-4 & 4808.5 & 4808.56 & 4808.76 & 4810.64 & 4809.93 & 4809.03 \\
\hline СРP-55-06 & 4805.69 & 4808.33 & 4808.8 & 4808.32 & 4807.77 & 4805.90 \\
\hline
\end{tabular}


Table 4-2. (continued).

\begin{tabular}{|c|c|c|c|c|c|c|}
\hline Well Name & Nov. 15-16, 2005 & Jan. 16-17, 2006 & March 14-15, 2006 & May 16-17, 2006 & July 19-20, 2006 & Sept. 19-20, 2006 \\
\hline MW-2 & 4805.58 & 4808.32 & 4808.62 & 4808.57 & 4807.81 & 4805.98 \\
\hline MW-4-2 & 4802.71 & 4805.85 & 4808.1 & 4808.11 & 4807.92 & 4807.46 \\
\hline MW-5-2 & 4796.28 & 4795.76 & 4795.42 & 4795.01 & 4795.93 & 4794.17 \\
\hline MW-8 & Dry & Dry & Dry & Dry & Dry & Dry \\
\hline MW-10-2 & 4767.36 & 4767.77 & 4768.08 & 4767.48 & 4767.82 & Dry \\
\hline MW-12-2 & Dry & Dry & Dry & Dry & Dry & Dry \\
\hline MW-18-2 & Dry & Dry & Dry & Dry & 487.92 \\
\hline \begin{tabular}{l} 
ICPP-2018 \\
\hline
\end{tabular} & 4806.74 & 4806.87 & 4807.79 & 4808.17 & 4807.19 & 4805.84 \\
\hline $\begin{array}{l}\text { ICPP-2019 } \\
\text { a. All WCF monitoring network wells were measured within a 24-hr period. } \\
\text { asl = above sea level. } \\
\text { bmp = below measuring point. }\end{array}$ & 4805.53 & 4808.68 & 4808.53 & 4805.96 \\
\hline
\end{tabular}




\subsection{Monitoring Well Network Compliance Statement}

Permit Condition III.H.3.a. requires a summary/statement whether the monitoring network as described in the WCF post-closure permit currently satisfies the requirements of IDAPA 58.01.05.008 (40 CFR 264.97(a)). The DEQ conducted a comprehensive groundwater monitoring evaluation for the WCF monitoring network and transmitted the CME Report to the Department of Energy Idaho Operations Office (DOE-ID) on August 25, 2004 (Bullock August 25, 2004). This report noted as a major finding that the "WCF monitoring network does not currently provide sufficient wells (installed at appropriate locations and depths) to represent the quality of the groundwater passing the point of compliance (IDAPA 58.01.05.008 [40 CFR 264.97(a)]).”

DOE-ID submitted a proposal (Mascareñas December 9, 2004), performed an in-depth evaluation of the existing monitoring well network, and identified suitable monitoring wells to replace the dry wells within the current monitoring network. Beginning with the February 2005 quarterly sampling event, upper perched groundwater samples were obtained and analyzed for the constituents listed in Table 3 of the WCF post-closure permit from supplemental wells CPP-55-06 and MW-10-2 in addition to the WCF monitoring network wells. A work plan for the installation of two new WCF monitoring wells was submitted to DEQ in January 2005 (McNeel January 12, 2005) and was conditionally approved by DEQ (Bullock January 19, 2005). The two new WCF wells were constructed in accordance with the approved work plan during January through early April 2005. These new wells are known as ICPP-2018 and ICPP-2019 or tank farm south (TFS) and tank farm southeast (TFSE), respectively, and have been sampled quarterly since their completion.

A Class 2 permit modification request to revise the WCF permit to add wells ICPP-2018, ICPP-2019, and MW-10-2 as monitoring wells; change well CPP-55-06 from a water elevation well to a monitoring well; remove well MW-4-2 as a water elevation well; and change groundwater sampling and analysis procedures and monitoring schedule was submitted to the DEQ on November 14, 2005, and was approved by DEQ on January 17, 2006. The addition of these wells into the WCF monitoring network provides a total of three background wells and six point-of-compliance wells. Even if two of the point-of-compliance wells (MW-12-2 and MW-18-2) continue to be dry, the current WCF monitoring network is expected to continue to satisfy the requirements of IDAPA 58.01.05.008 (40 CFR 264.97(a)). 


\section{MAINTENANCE OF GROUNDWATER MONITORING EQUIPMENT}

All monitoring wells are inspected quarterly, at a minimum. In addition to the quarterly inspections, the overall condition of a monitoring well is visually inspected at each visit to the well, including the quarterly sampling events and the bimonthly water level surveys. Maintenance problems encountered at any well location are addressed following their identification. Examples of possible maintenance problems at monitoring wells could include inoperable locks, cracked surface casings, and damaged cement pads. No well maintenance problems were identified during the time period covered by this semiannual report.

A summary of work performed on groundwater monitoring wells and equipment during the time period covered by this semiannual report is included in Table 5-1.

Table 5-1. Installation of groundwater monitoring equipment.

\begin{tabular}{ccl}
\hline Date & Monitoring Well & Description of Maintenance Activity \\
\hline $5 / 1 / 2006$ & MW-10 & Replaced module on Monsoon pump \\
\hline
\end{tabular}




\section{INSPECTIONS}

Inspections are required under Permit Condition IV.C.1. and described in Attachment 2, Section D, of the post-closure permit. Inspections of the landfill cap and two brass survey benchmarks are required semiannually. The current WCF monitoring network includes 13 wells, all of which were inspected quarterly during the report period. Inspection forms are completed for these inspections; examples of the forms are included in Attachment 2 of the post-closure permit.

\subsection{Monitoring Wells}

No deficiencies were identified during inspections of monitoring network wells for the time period covered by this semiannual report, as required by Permit Condition III.H.6.

\subsection{Surveyed Benchmarks}

No deficiencies were identified during the September 12, 2006, semiannual inspection of surveyed benchmarks associated with the WCF cap.

\subsection{WCF Cap}

No deficiencies were identified during the September 12, 2006, semiannual inspection of the WCF cap. 
6-2 


\section{OTHER NONCOMPLIANCE (I.U.)}

Permit Condition I.U. requires reporting of all instances of noncompliance not otherwise required to be reported under Permit Condition I.R. (i.e., planned changes in the facility or activity that may result in noncompliance with the requirements of this permit) or Permit Condition I.T. (i.e., noncompliance that may endanger human health or the environment).

No "other noncompliance" occurred during the period covered by this semiannual report. 


\section{REFERENCES}

40 CFR 264, Appendix IX, 2006, "Ground-Water Monitoring List," Code of Federal Regulations, Office of the Federal Register, May 2006.

40 CFR 264.97, 2006, "General Ground-Water Monitoring Requirements," Code of Federal Regulations, Office of the Federal Register, May 2006.

Bullock, R. E., DEQ, letter to T. Safford, DOE Idaho, February 12, 2004, "Issues Associated with the Waste Calcine Facility Post Closure Care Partial Permit on the Idaho National Engineering and Environmental Laboratory (EPA ID No. ID4890008952)," CCN 48069.

Bullock, R. E., DEQ, letter to T. J. Safford, DOE-ID, August 25, 2004, “Transmittal of the Comprehensive Ground Water Monitoring Evaluation for the Waste Calcine Facility at the INTEC on the Idaho National Engineering and Environmental Laboratory," EPA ID No. ID4890008952, CCN 51954.

Bullock, R. E., DEQ, letter to T. J. Safford, DOE-ID, January 19, 2005, “Conditional Approval of the Well Installation Work Plan (Plan) for the Waste Calcine Facility (WCF) Post Closure Care Permit," CCN 54622.

Bullock, R. E., DEQ, letter to J. Medema, DOE-ID, April 7, 2006, "Receipt of the March 29, 2006 Permit Condition III.D.5 Notification Concerning Ground Water Sampling Data for the Waste Calcining Facility at INTEC on Idaho National Laboratory (INL-EPA ID No. ID4890008952)," CCN 302493.

DEQ, 2004, HWMA/RCRA Post-Closure Permit for the Idaho Nuclear Technology and Engineering Center Waste Calcine Facility at the Idaho National Engineering and Environmental Laboratory, EPA ID No. ID4890008952, Idaho Department of Environmental Quality, as modified June 10, 2004, and as modified January 17, 2006.

DOE-ID, 2006a, Fall 2005 Semiannual (III.H. and I.U.) Report for the HWMA/RCRA Post-Closure Permit for the INTEC Waste Calcining Facility at the INL, DOE-ID-11265, Rev. 0, U.S. Department of Energy Idaho Operations Office, January 2006.

DOE-ID, 2006b, Spring 2006 Semiannual (III.H. and I.U.) Report for the HWMA/RCRA Post-Closure Permit for the INTEC Waste Calcining Facility at the INL, DOE-ID-11283, Rev. 0, U.S. Department of Energy Idaho Operations Office, June 2006.

DOE-NE-ID, 2004, Spring Semiannual (III.H. and I.U.) Report for the HWMA/RCRA Post-Closure Permit for the INTEC Waste Calcining Facility at the INEEL, DOE/NE-ID-11166, Rev. 0, U.S. Department of Energy Idaho Operations Office, June 2004.

DOE-NE-ID, 2005a, Fall 2004 Semiannual (III.H. and I.U.) Report for the HWMA/RCRA Post-Closure Permit for the INTEC Waste Calcining Facility at the INL, DOE/NE-ID-11203, Rev. 0, U.S. Department of Energy Idaho Operations Office, January 2005.

DOE-NE-ID, 2005b, Spring 2005 Semiannual (III.H. and I.U.) Report for the HWMA/RCRA Post-Closure Permit for the INTEC Waste Calcining Facility at the INL, DOE/NE-ID-11236, Rev. 0, U.S. Department of Energy Idaho Operations Office, June 2005. 
English, B., DEQ, to N. Hutten and A. Boehmer, ICP, January 12, 2006, “WCF Toluene,” CCN 302729.

Hutten, N., ICP, email to B. English, DEQ, January 11, 2006, "WCF Toluene."

IDAPA 58.01.05.008, 2006, "Standards for Owners and Operators of Hazardous Waste Treatment, Storage and Disposal Facilities," Idaho Department of Administrative Procedures Act, April 11, 2006.

Mascareñas, C. S., BBWI, letter to B. R. Monson, DEQ, January 6, 2004, "Hazardous Waste Management Act/Resource Conservation and Recovery Act Post Closure Permit for Waste Calcining Facility at the Idaho Nuclear Technology and Engineering Center Clarifications and Submittal Date for Combined III.H. and I.U. Reports," CCN 47101.

Mascareñas, C. S., ICP, letter to B. R. Monson, DEQ, December 9, 2004, "Response to Comprehensive Ground Water Monitoring Evaluation for the Waste Calcine Facility on the Idaho National Engineering and Environmental Laboratory," CCN 53933.

McNeel, K., ICP, letter to B. R. Monson, DEQ, March 29, 2006, "Hazardous Waste Management Act/Resource Conservation and Recovery Act Post-closure Permit for the Waste Calcining Facility Notification for the January 30 - February 1, 2006 Sampling Event, and Toluene Results Discussion," CCN 302375.

McNeel, K., ICP, letter to B. R. Monson, DEQ, August 7, 2006, "Hazardous Waste Management Act/Resource Conservation and Recovery Act Post-closure Permit for the Waste Calcining Facility Status for the May 2006 Sampling Event, and Toluene Results Discussion” CCN 303198.

McNeel, K., ICP, letter to B. R. Monson, DEQ, October 18, 2006, "Hazardous Waste Management Act/Resource Conservation and Recovery Act Post-closure Permit for the Waste Calcining Facility Notification for the July 31 thru August 2, 2006 Sampling Event" CCN 303662.

Medema, J. E., DOE, letter to B. R. Monson, DEQ, August 30, 2006, "Eleventh Quarterly Groundwater Data Summary for the Volume 21 Hazardous Waste Management Act (HWMA)/Resource Conservation and Recovery Act (RCRA) Post-Closure Permit for the Waste Calcining Facility (WCF) at the Idaho Nuclear Technology and Engineering Center (INTEC) (OS-ETSD-06-107)," CCN 303374.

Medema, J. E., DOE, letter to B. R. Monson, DEQ, November 17, 2006, "Twelfth Quarterly Groundwater Data Summary for the Volume 21 Hazardous Waste Management Act (HWMA)/Resource Conservation and Recovery Act (RCRA) Post-Closure Permit for the Waste Calcining Facility (WCF) at the Idaho Nuclear Technology and Engineering Center (INTEC) (OS-ETSD-06-146)," CCN 303882.

Monson, B. R., DEQ, letter to T. Safford, DOE-ID, January 17, 2006, "Class 2 Permit Modification for the Waste Calcining Facility located at the Idaho Nuclear Technology and Engineering Center (INTEC) on the Idaho National Laboratory, EPA ID No. ID4890008952,” CCN 302066.

Safford, T. J., DOE, letter to B. R. Monson, DEQ, February 23, 2006, "Ninth Quarterly Groundwater Data Summary for the Volume 21 Hazardous Waste Management Act (HWMA)/Resource Conservation and Recovery Act (RCRA) Post-Closure Permit for the Waste Calcining Facility (WCF) at the Idaho Nuclear Technology and Engineering Center (INTEC) (OS-ETSD-06-029)," CCN 302168. 


\section{Appendix A}

\section{Chain-of-Custody Information}

Chain-of-Custody Forms for WCF Groundwater, May 2006 (11th Quarter) .........................................-3

Chain-of-Custody Forms for WCF Groundwater, July-August 2006 (12th Quarter) .......................... A-15 


$$
\text { A-2 }
$$


Chain-of-Custody Forms for WCF Groundwater, May 2006 (11th Quarter) 


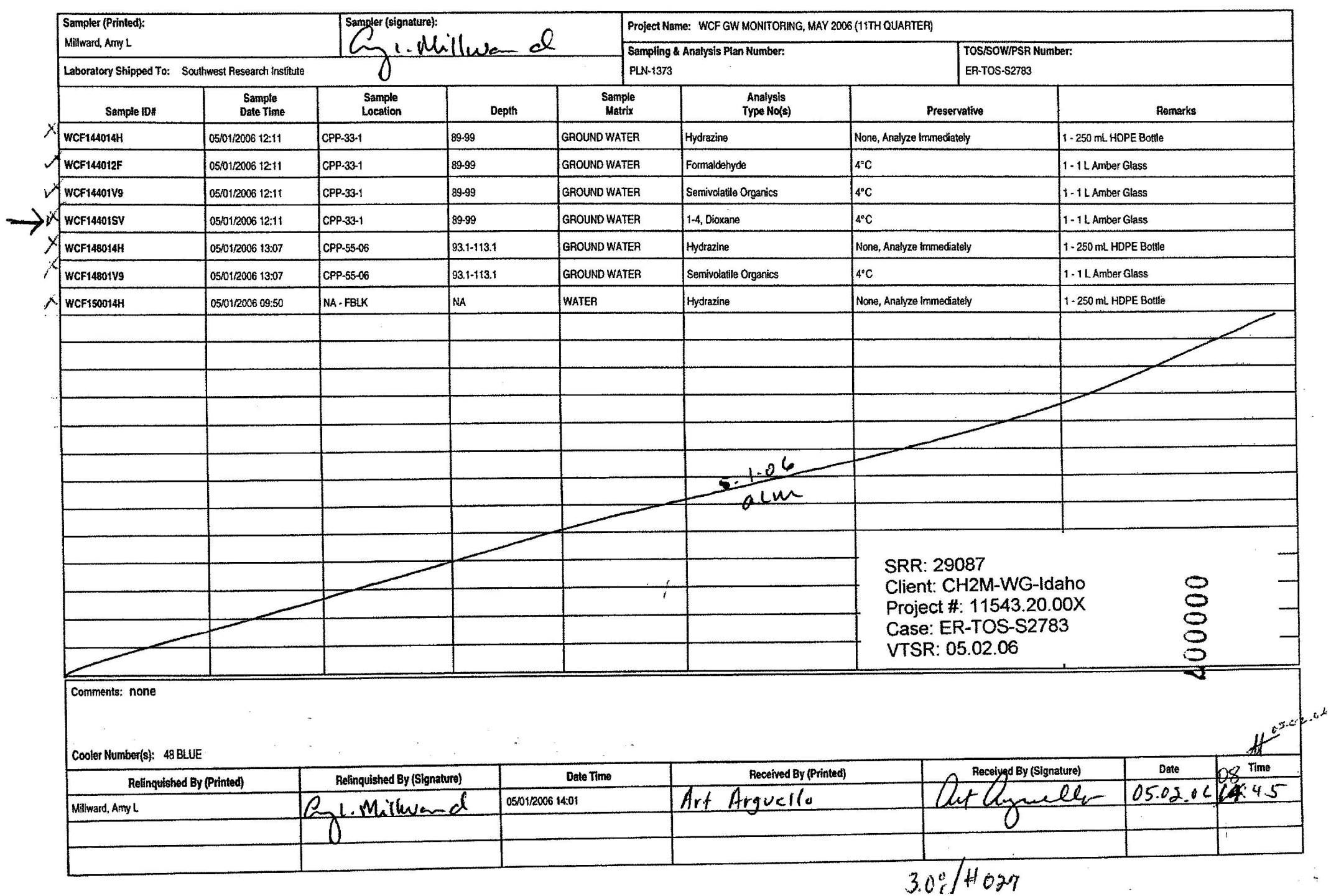




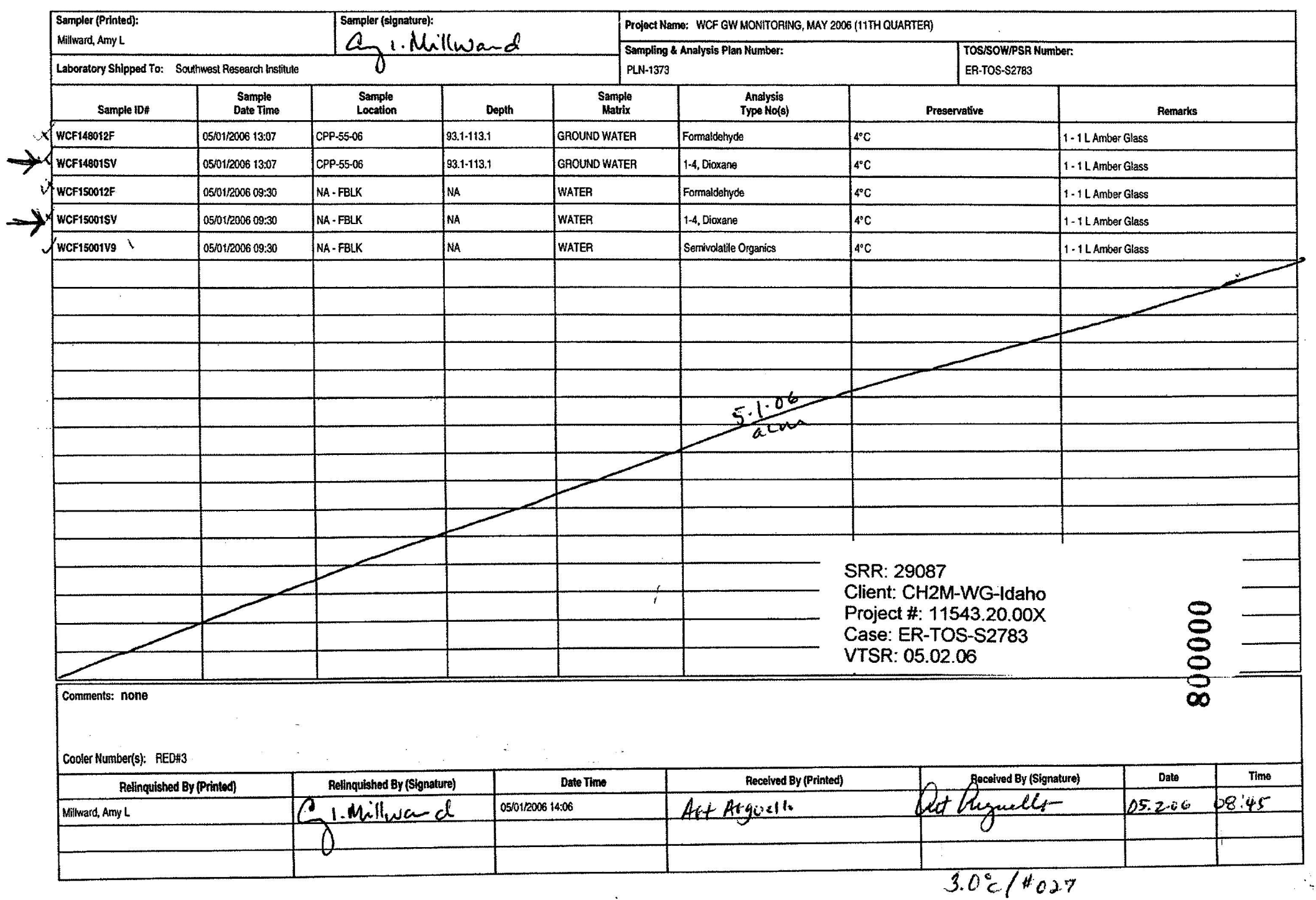




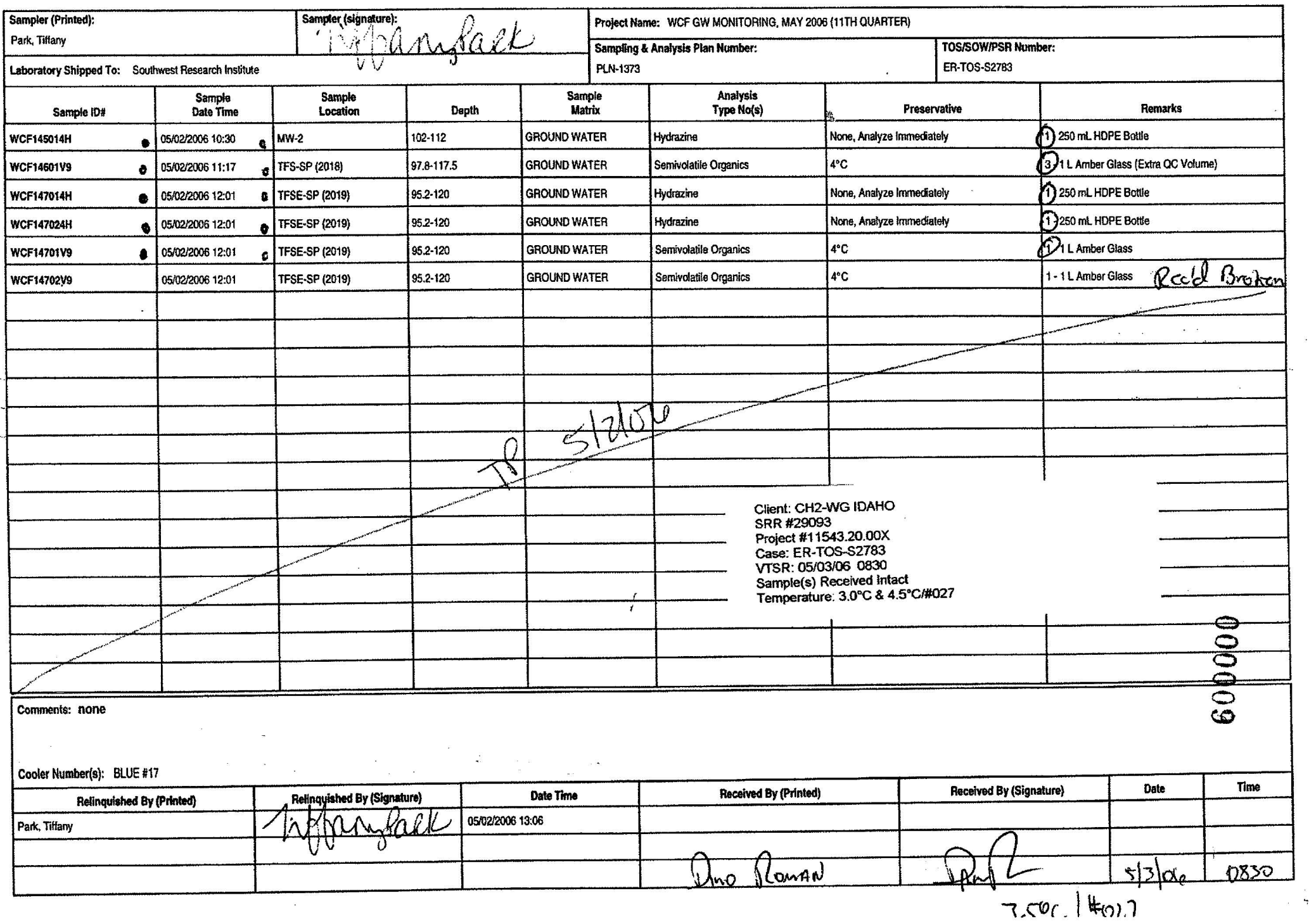


Page 1 of 1

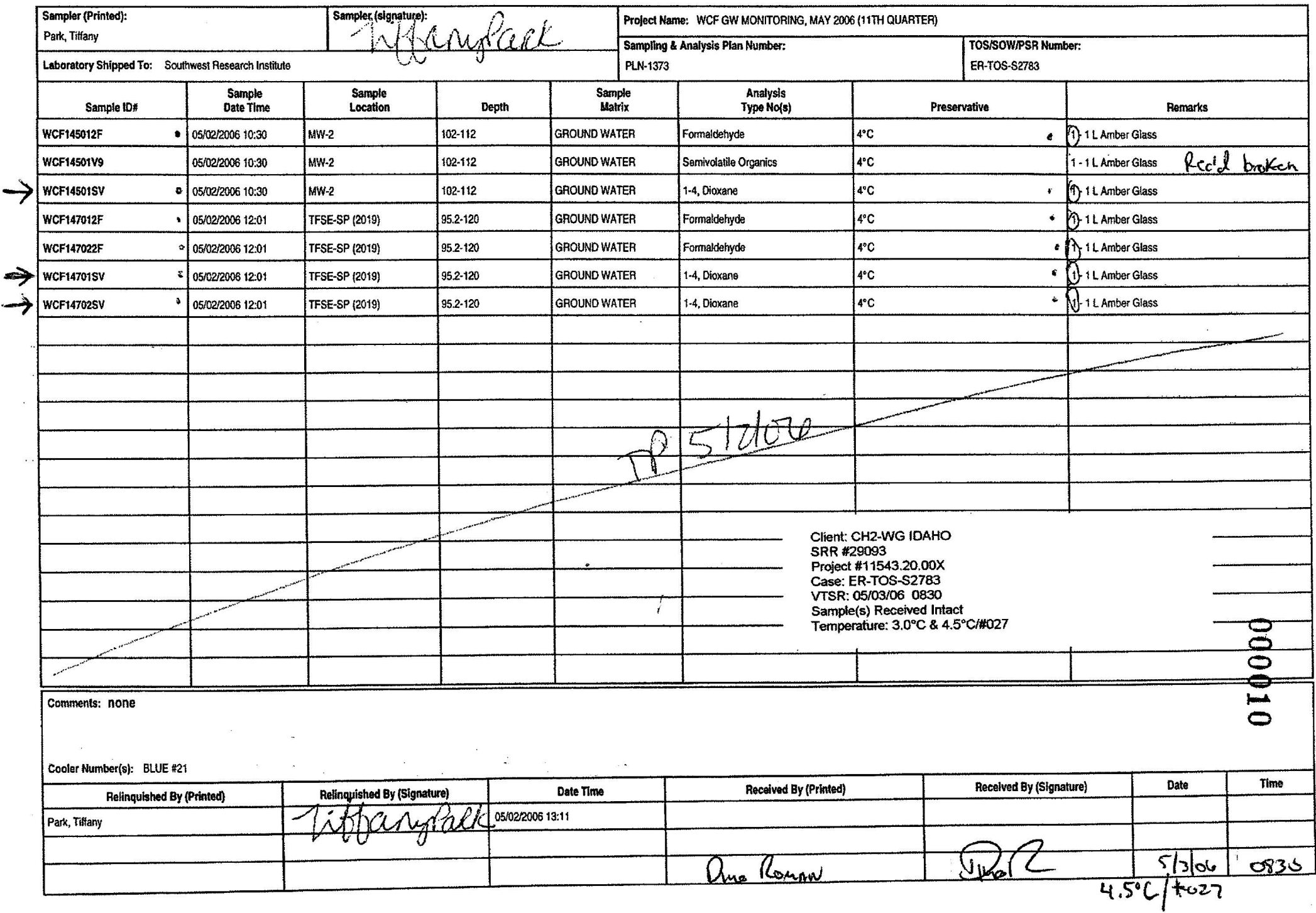




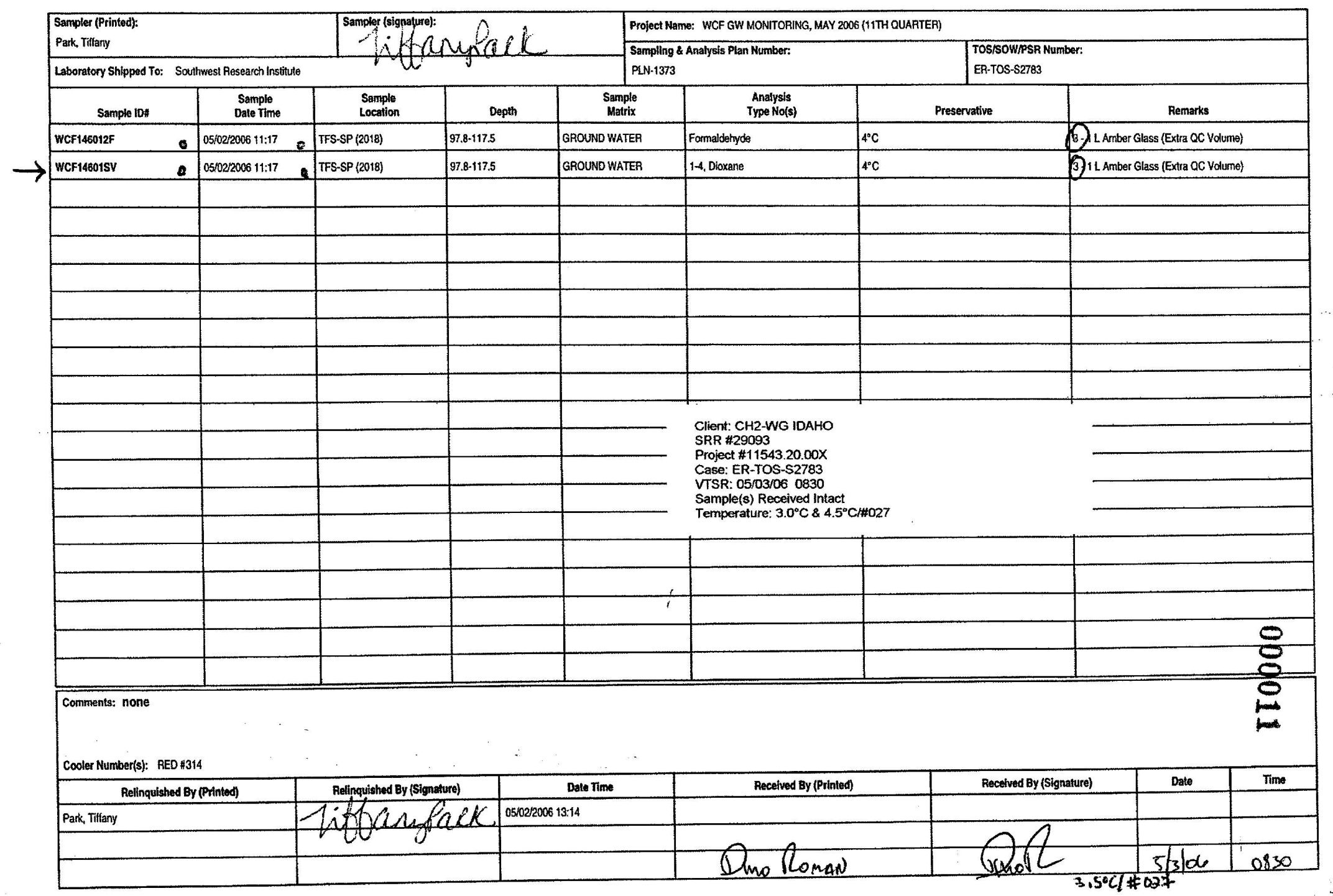




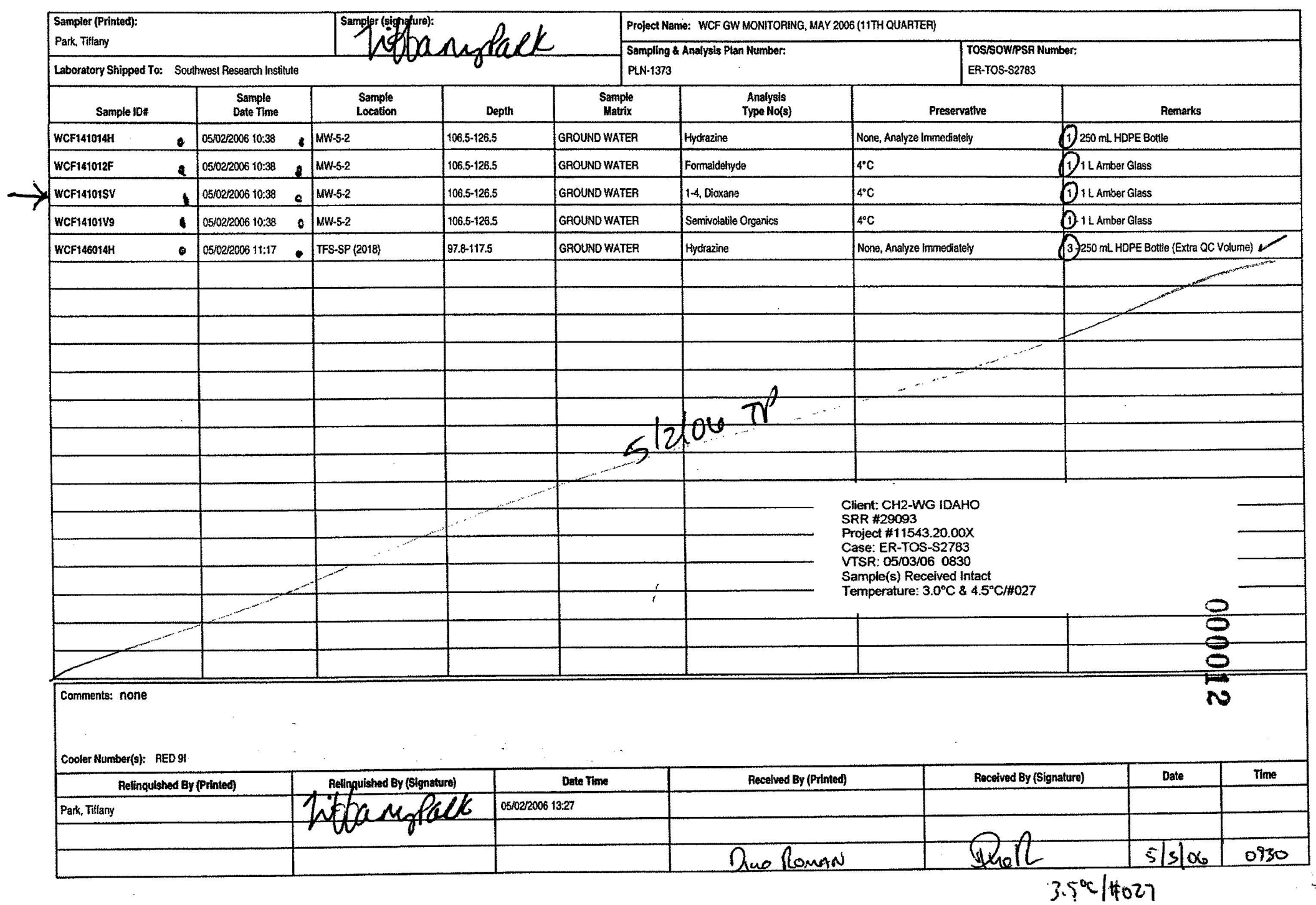




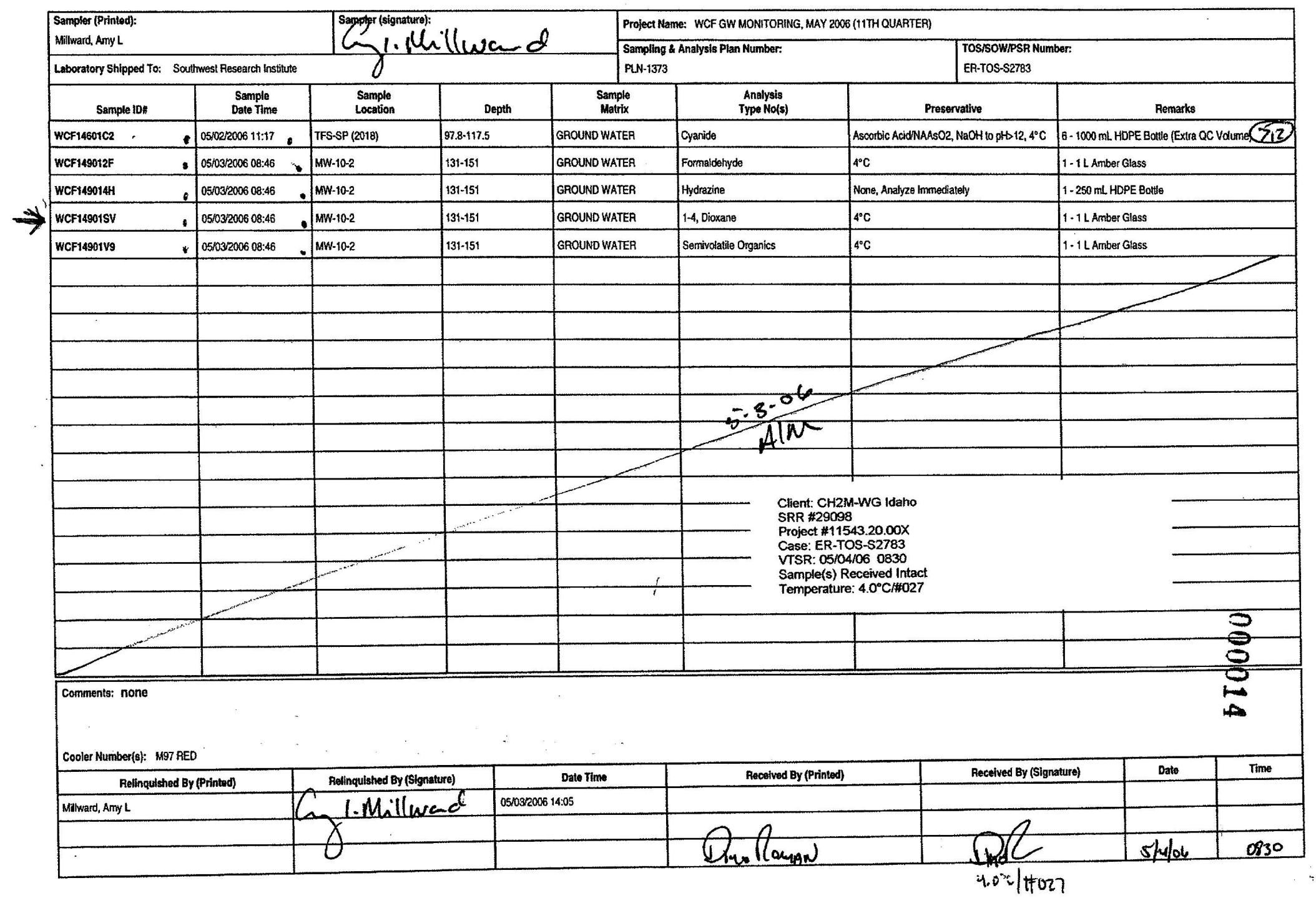




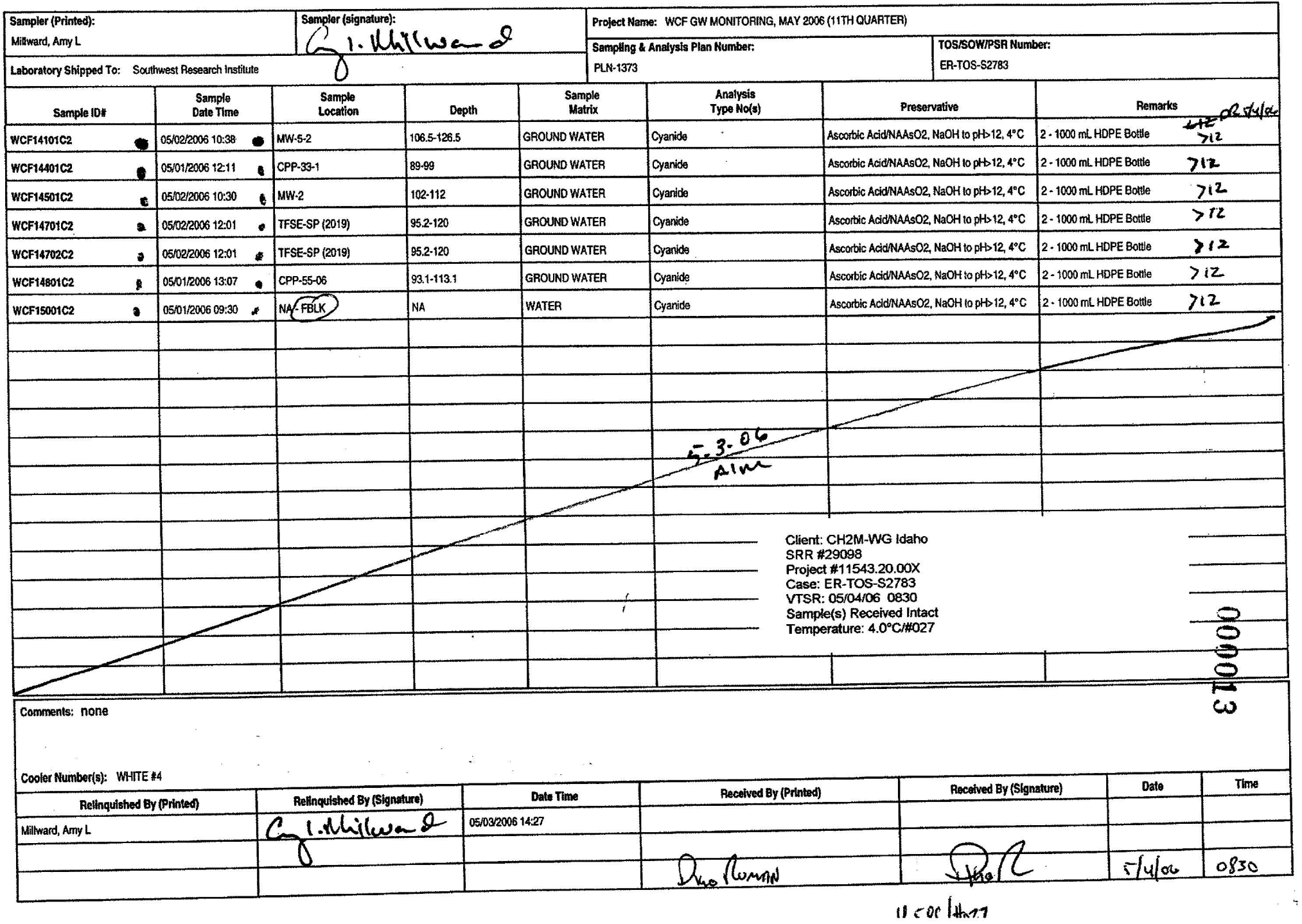




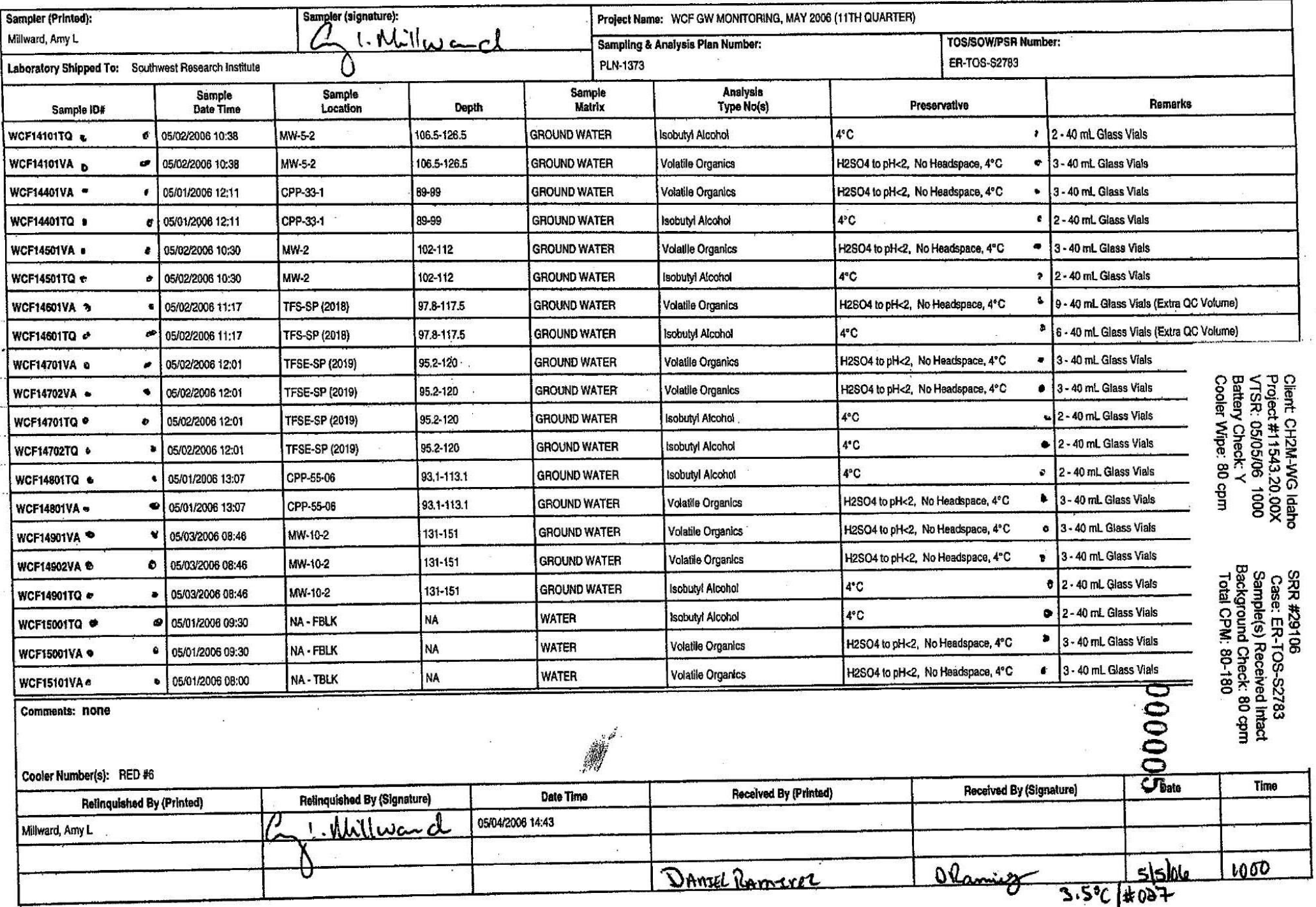




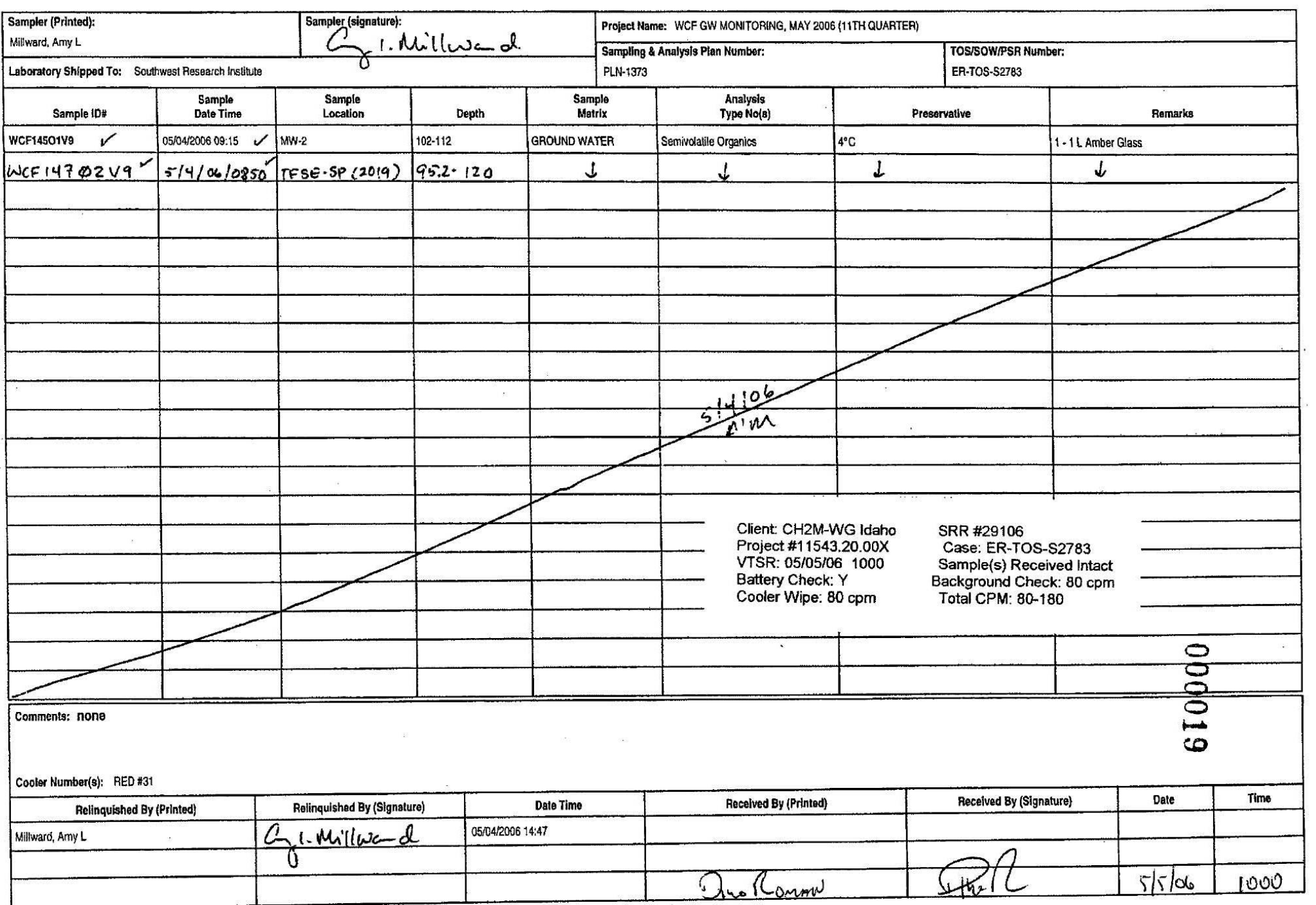


Page 1 of 1

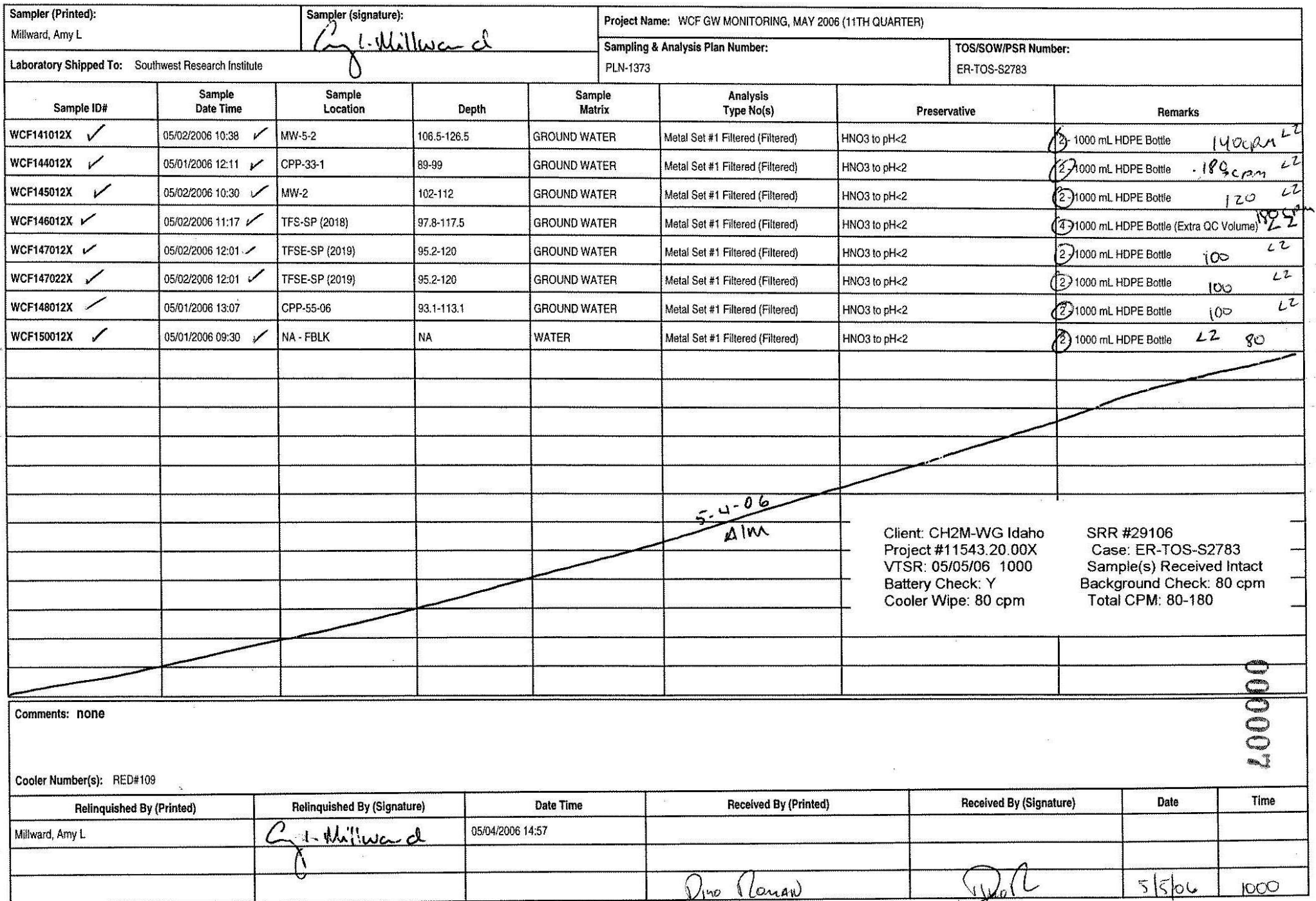


Chain-of-Custody Forms for WCF Groundwater, July-August 2006 (12th Quarter) 
A-16 


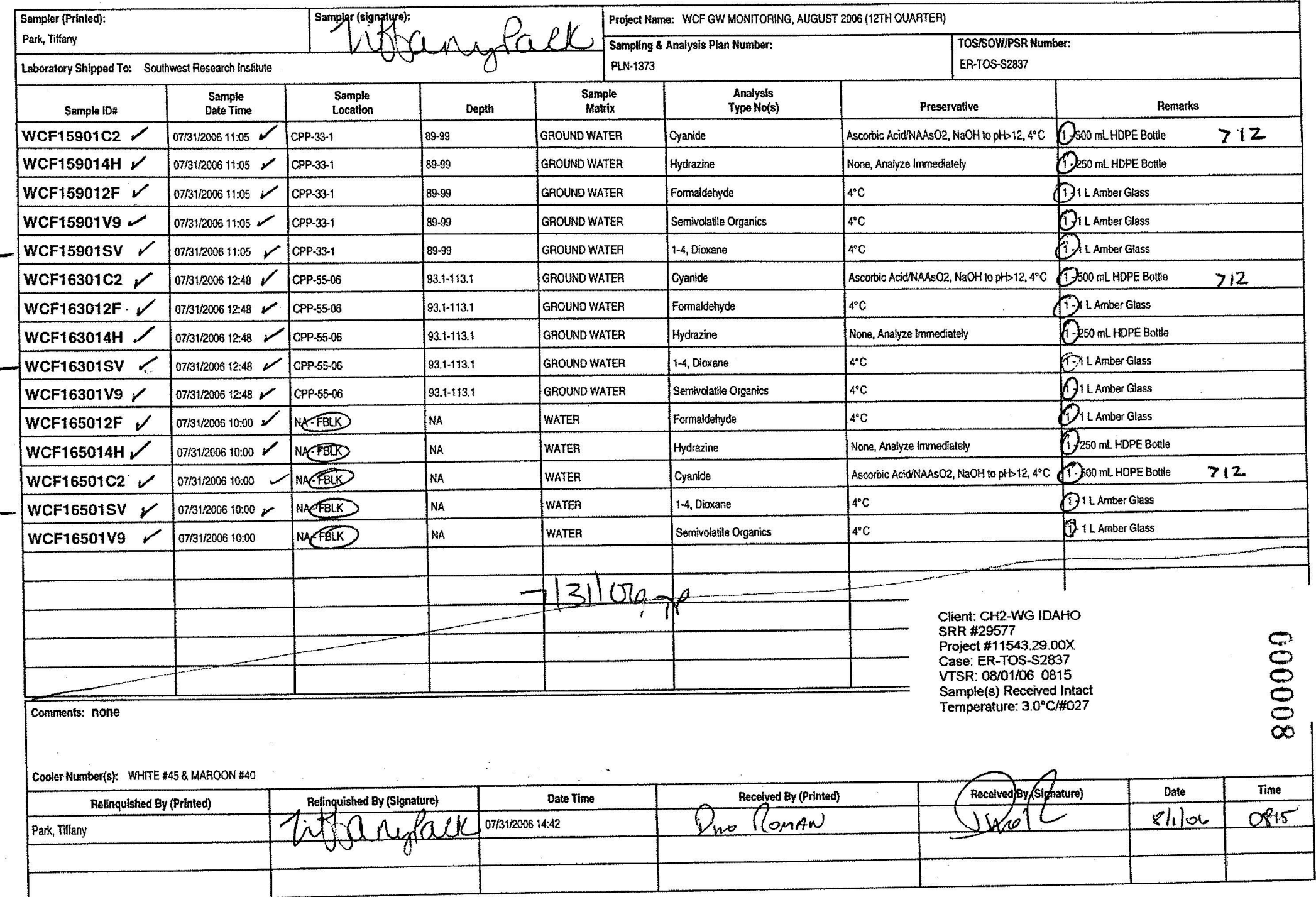




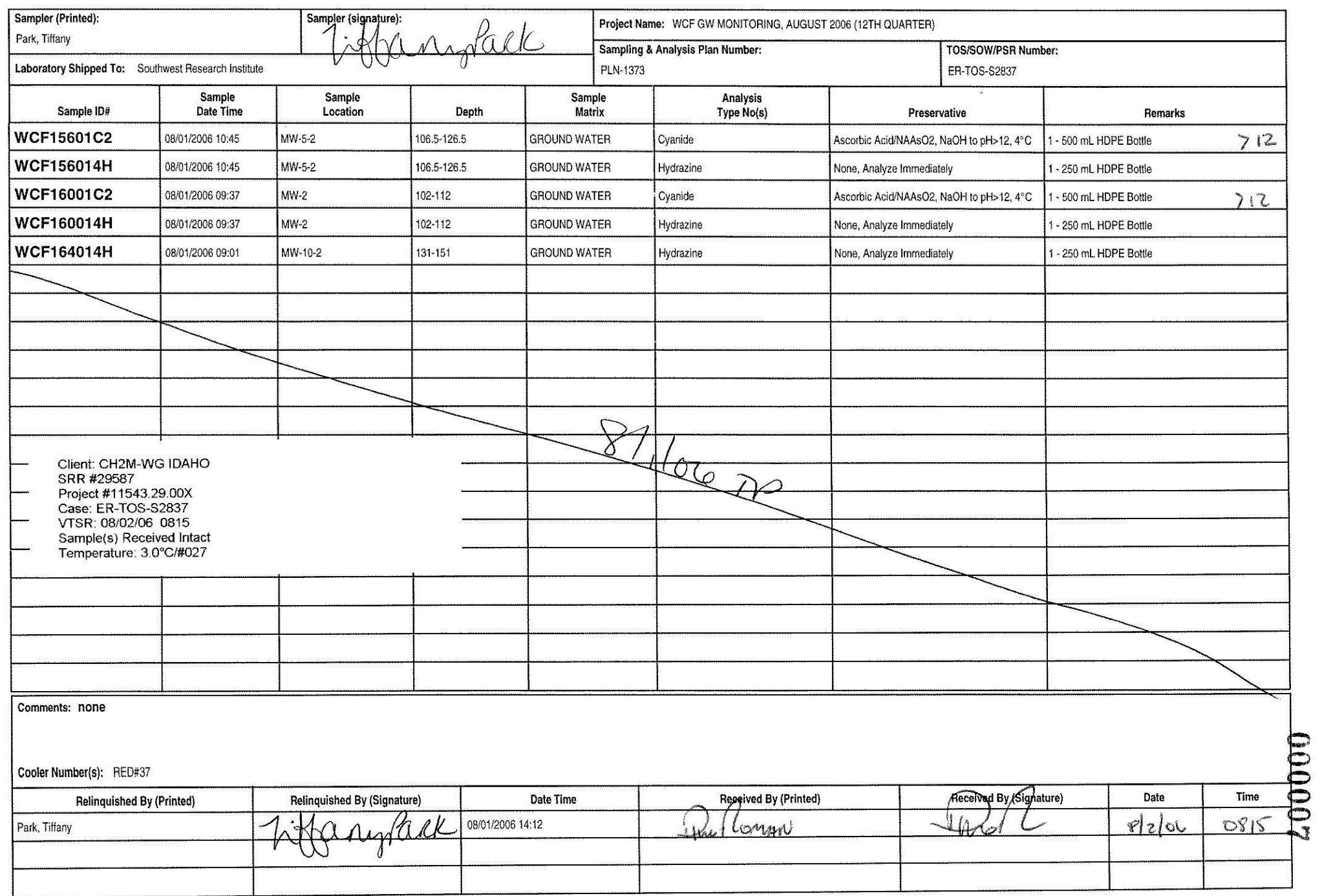




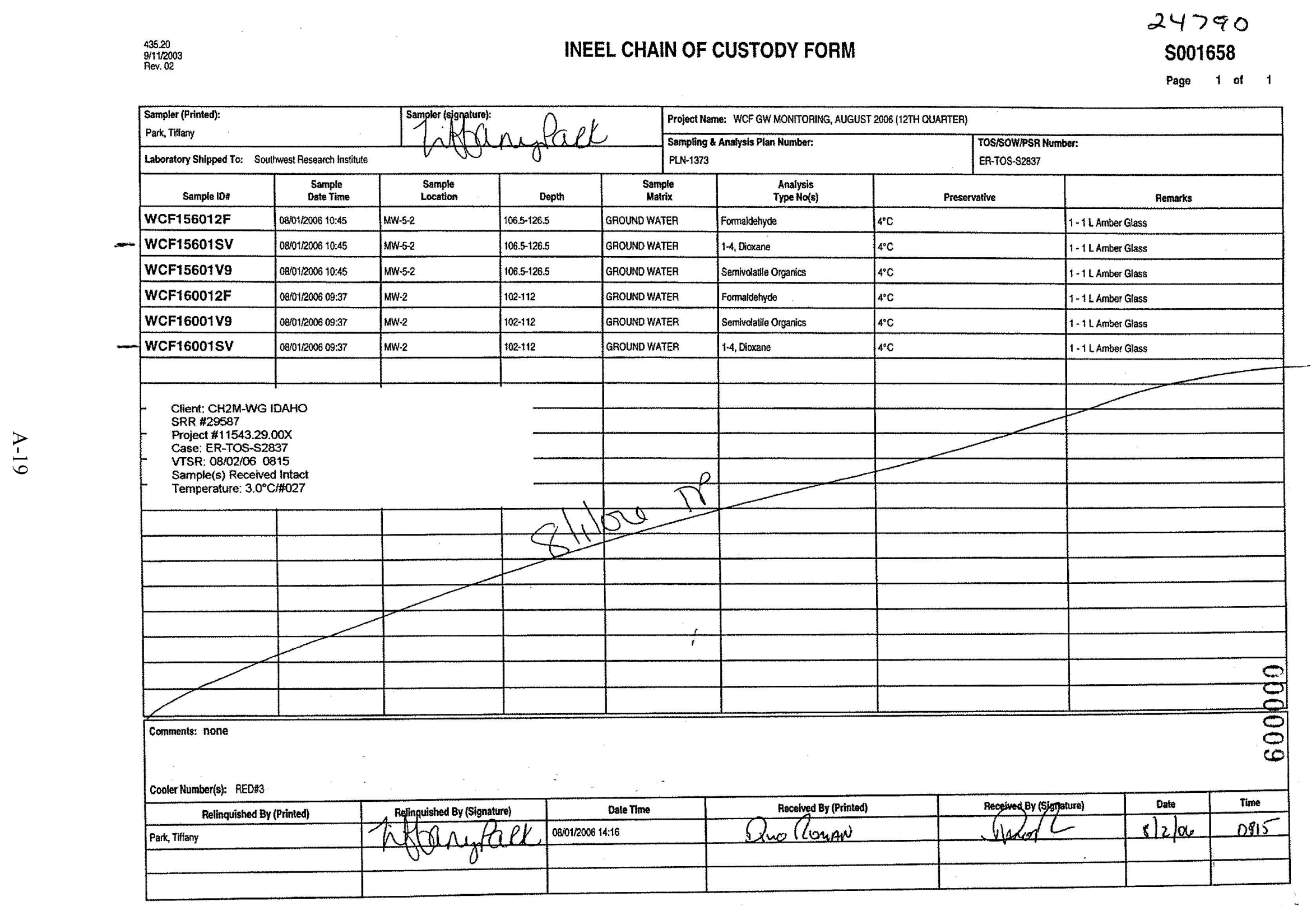




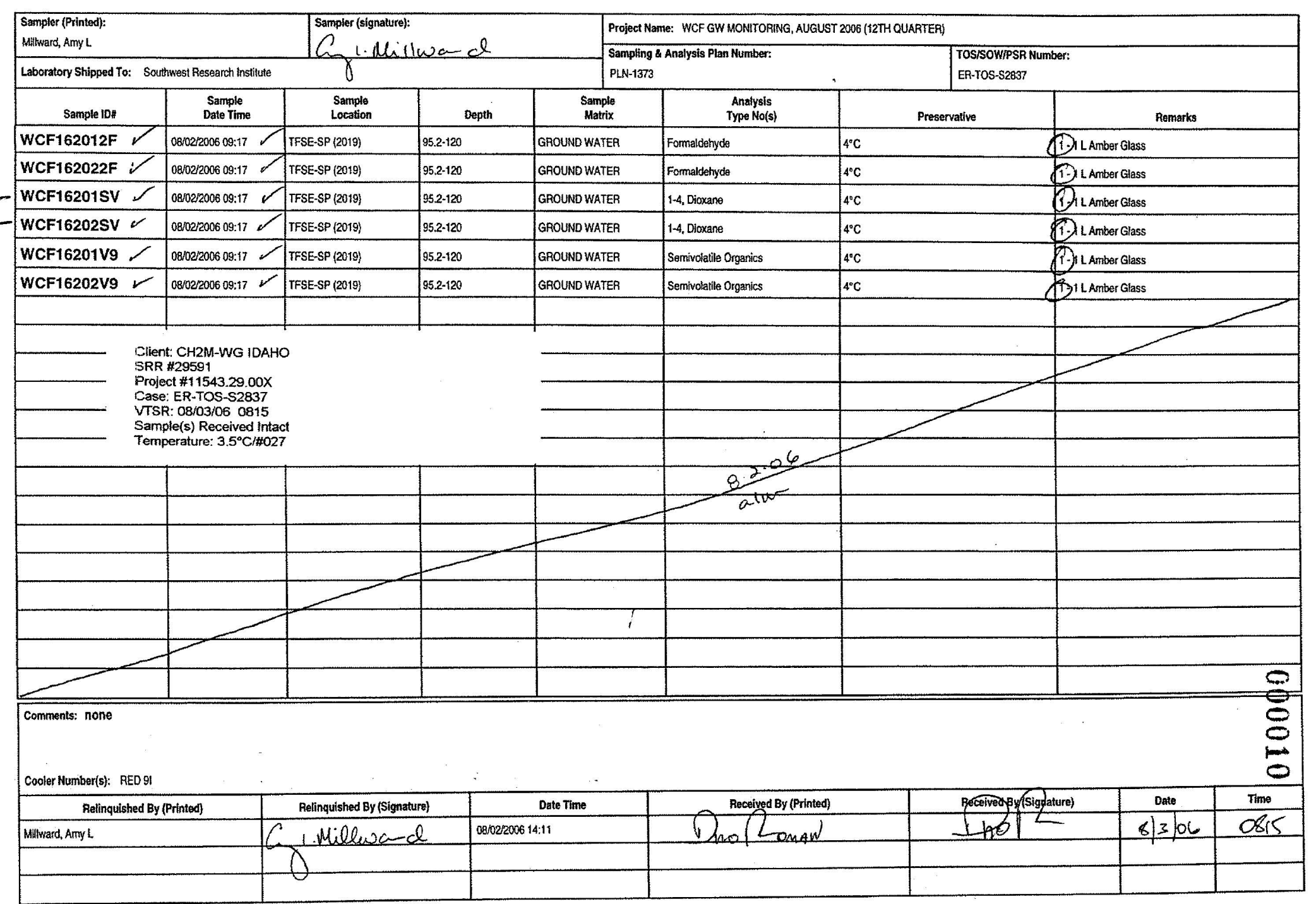




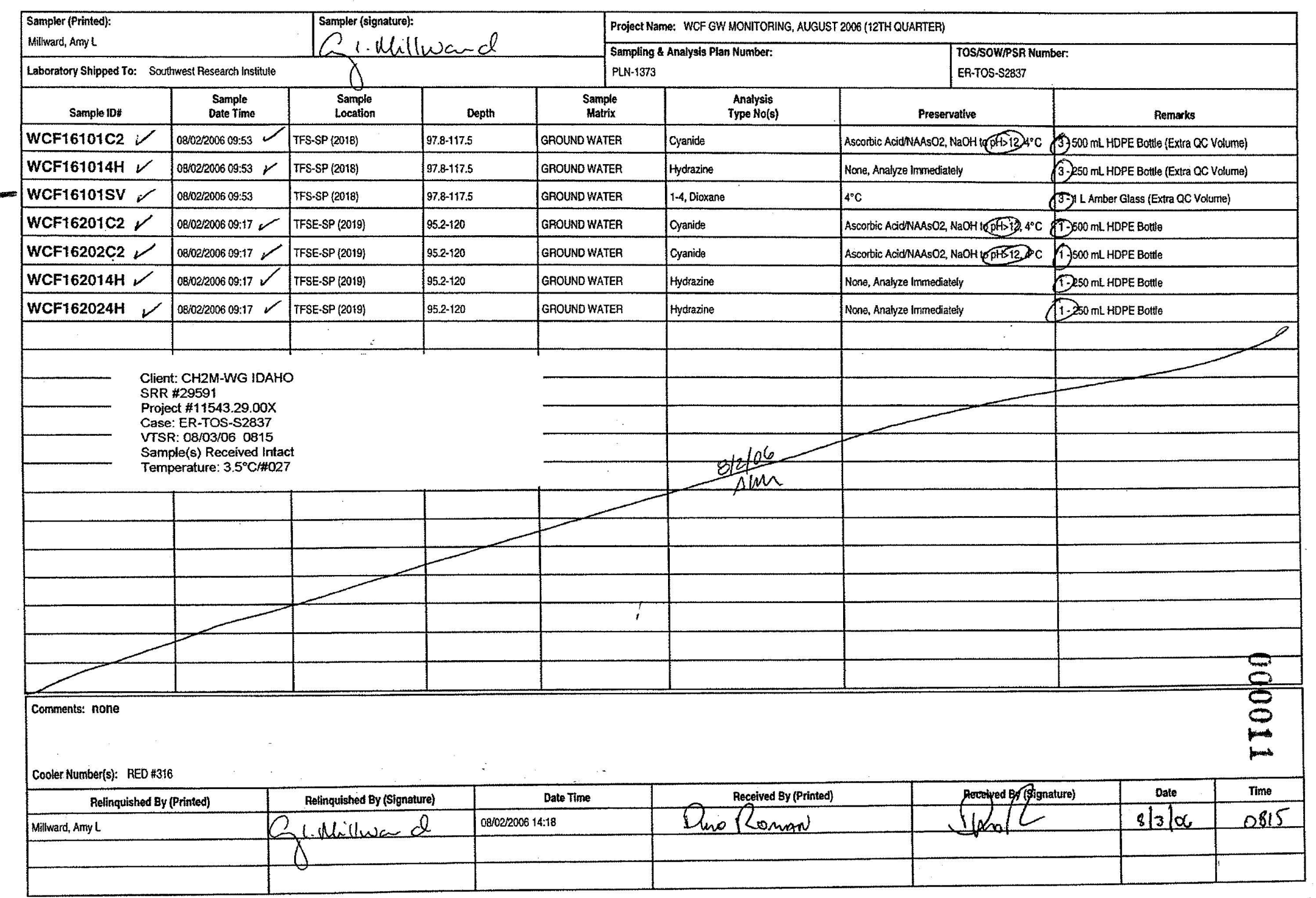




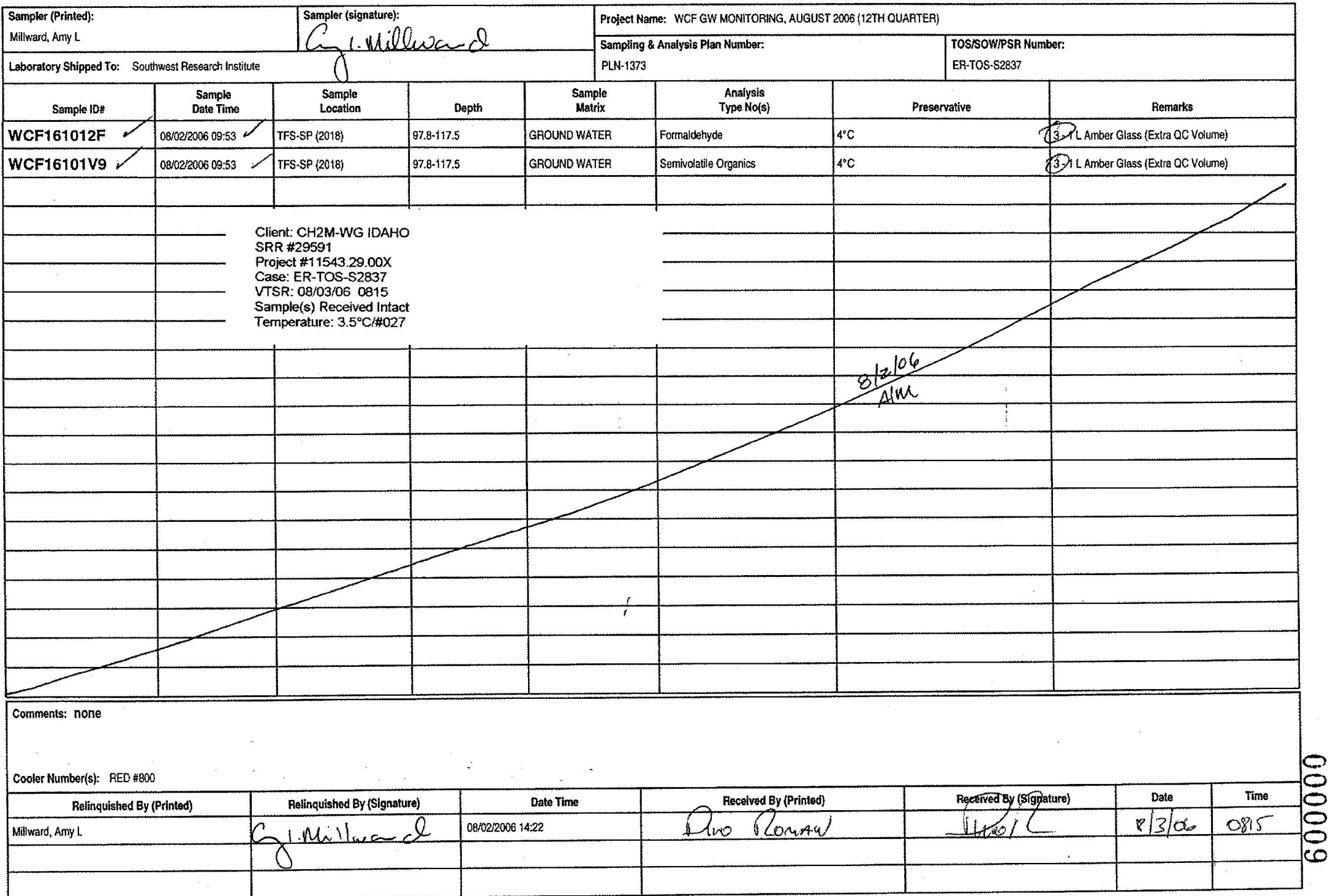




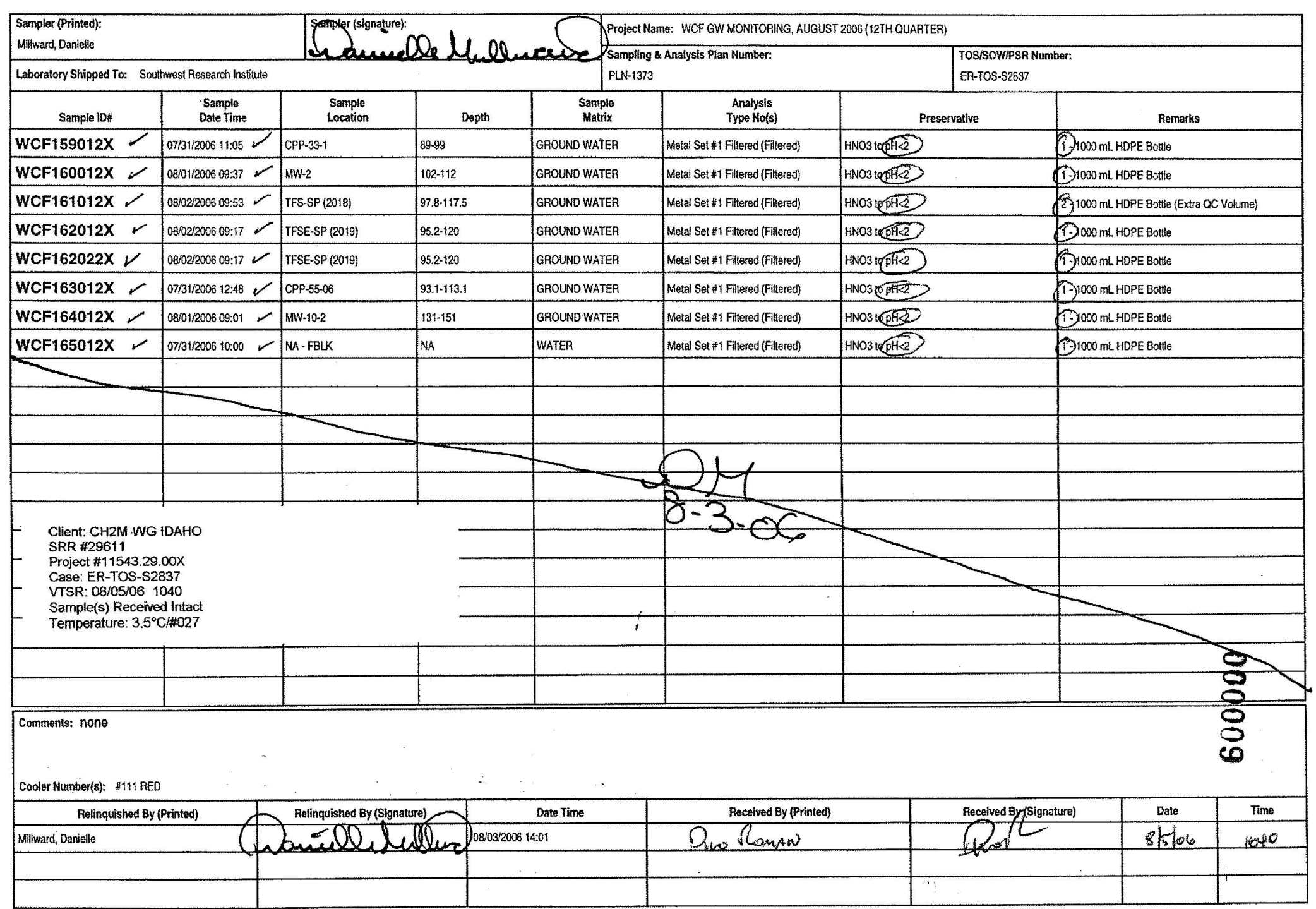




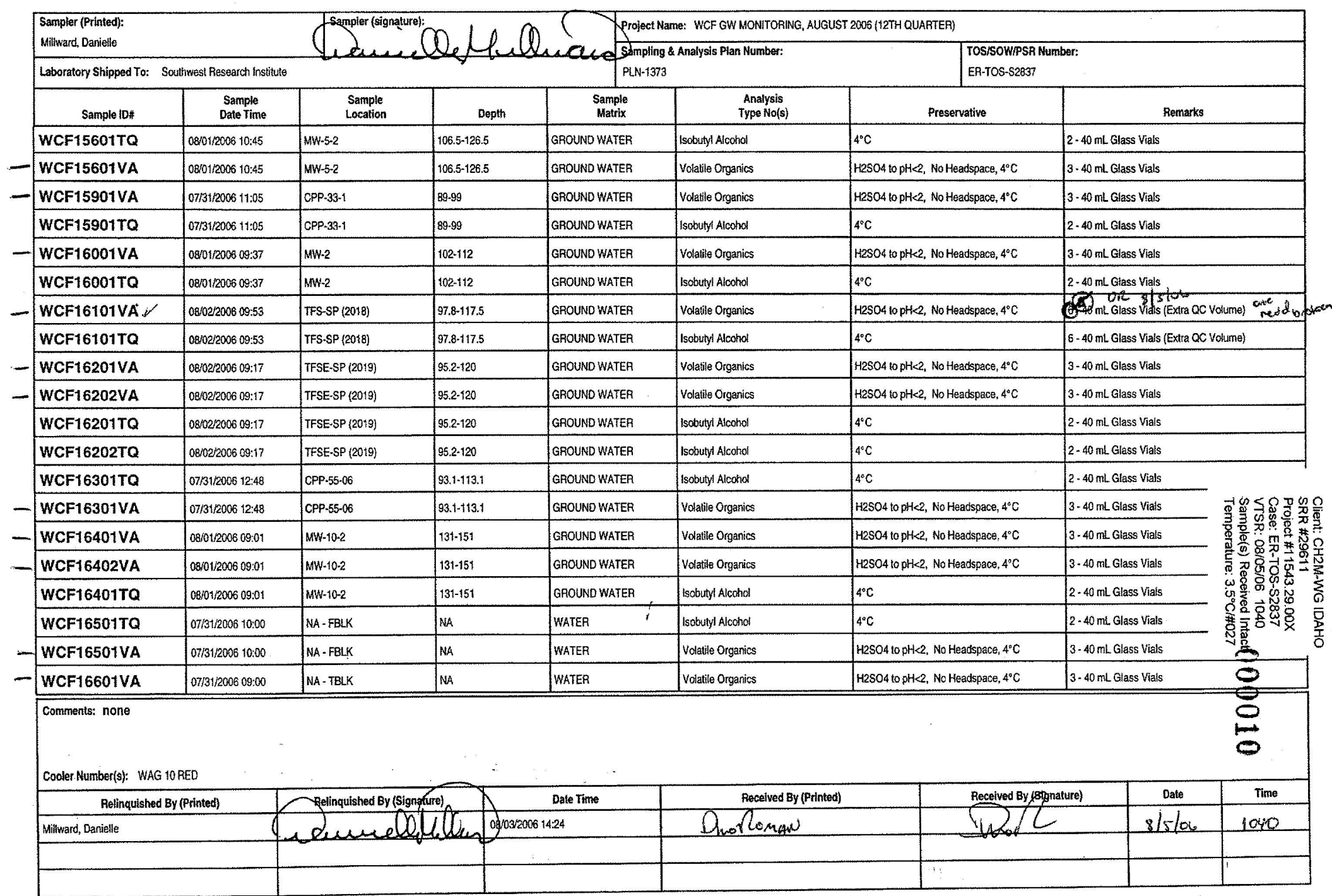




\section{Appendix B}

\section{Groundwater Analytical Data and Quality Assurance/Quality Control Information}

\section{TABLES}

B-1. WCF analytical results from May 1-4, 2006, (11th quarter) sampling event

B-3

B-2. WCF analytical results from July 31-August 2, 2006, (12th quarter) sampling event .......

B-13

B-3. Result qualifier and validation flag definitions

B-22 
B-2 


\section{Appendix B}

\section{Groundwater Analytical Data and Quality Assurance/Quality Control Information}

\section{Compliance Monitoring Program}

Groundwater Sampling Results

Table B-1. WCF analytical results from May 1-4, 2006, (11th quarter) sampling event. (See Table B-3 for qualifier and flag definitions.)

\begin{tabular}{|l|c|l|c|c|c|c|l|l|}
\hline \multicolumn{1}{|c}{ Constituent } & $\begin{array}{c}\text { Conc. } \\
(\mu \mathrm{g} / \mathrm{L})\end{array}$ & \multicolumn{1}{|c|}{ Location } & $\begin{array}{c}\text { Lab } \\
\text { Qualifier }\end{array}$ & $\begin{array}{c}\text { Validation } \\
\text { Qualifier }\end{array}$ & $\begin{array}{c}\text { Date } \\
\text { Collected }\end{array}$ & $\begin{array}{c}\text { Date } \\
\text { Analyzed }\end{array}$ & $\begin{array}{c}\text { Sample } \\
\text { Number }\end{array}$ & $\begin{array}{c}\text { CAS } \\
\text { Number }\end{array}$ \\
\hline Aniline & 2.5 & CPP-33-1 & $\mathrm{U}$ & $\mathrm{R}$ & $5 / 1 / 06$ & $6 / 1 / 06$ & WCF14401V9 & $62-53-3$ \\
\hline Aniline & 2.5 & CPP-55-06 & $\mathrm{U}$ & $\mathrm{R}$ & $5 / 1 / 06$ & $6 / 1 / 06$ & WCF14801V9 & $62-53-3$ \\
\hline Aniline & 2.5 & ICPP-2018 & $\mathrm{U}$ & $\mathrm{R}$ & $5 / 2 / 06$ & $6 / 1 / 06$ & WCF14601V9 & $62-53-3$ \\
\hline Aniline & 2.5 & ICPP-2019 & $\mathrm{U}$ & $\mathrm{R}$ & $5 / 2 / 06$ & $6 / 1 / 06$ & WCF14701V9 & $62-53-3$ \\
\hline Aniline & 2.5 & ICPP-2019 & $\mathrm{U}$ & $\mathrm{R}$ & $5 / 2 / 06$ & $6 / 2 / 06$ & WCF14702V9(1) & $62-53-3$ \\
\hline Aniline & 2.5 & MW-10-2 & $\mathrm{U}$ & $\mathrm{R}$ & $5 / 3 / 06$ & $6 / 2 / 06$ & WCF14901V9 & $62-53-3$ \\
\hline Aniline & 2.5 & MW-2 & $\mathrm{U}$ & $\mathrm{R}$ & $5 / 2 / 06$ & $6 / 2 / 06$ & WCF14501V9(1) & $62-53-3$ \\
\hline Aniline & 2.5 & MW-5-2 & $\mathrm{U}$ & $\mathrm{R}$ & $5 / 2 / 06$ & $6 / 1 / 06$ & WCF14101V9 & $62-53-3$ \\
\hline Arsenic & 2.5 & CPP-33-1 & $\mathrm{U}$ & & $5 / 1 / 06$ & $5 / 22 / 06$ & WCF144012X & $7440-38-2$ \\
\hline Arsenic & 2.5 & CPP-55-06 & $\mathrm{U}$ & & $5 / 1 / 06$ & $5 / 22 / 06$ & WCF148012X & $74440-38-2$ \\
\hline Arsenic & 2.5 & ICPP-2019 & $\mathrm{U}$ & & $5 / 2 / 06$ & $5 / 22 / 06$ & WCF147012X & $74440-38-2$ \\
\hline Arsenic & 2.5 & MW-2 & $\mathrm{U}$ & & $5 / 2 / 06$ & $5 / 22 / 06$ & WCF145012X & $7440-38-2$ \\
\hline Arsenic & 2.5 & MW-5-2 & $\mathrm{U}$ & & $5 / 2 / 06$ & $5 / 22 / 06$ & WCF141012X & $7440-38-2$ \\
\hline Arsenic & 2.5 & TFSE-SP & $\mathrm{U}$ & & $5 / 2 / 06$ & $5 / 22 / 06$ & WCF147022X & $7440-38-2$ \\
\hline Arsenic & 2.9 & TFS-SP & $\mathrm{B}$ & & $5 / 2 / 06$ & $5 / 22 / 06$ & WCF146012X & $7440-38-2$ \\
\hline Barium & 154 & CPP-33-1 & & & $5 / 1 / 06$ & $5 / 22 / 06$ & WCF144012X & $7440-39-3$ \\
\hline Barium & 182 & CPP-55-06 & & & $5 / 1 / 06$ & $5 / 22 / 06$ & WCF148012X & $7440-39-3$ \\
\hline Barium & 200 & ICPP-2019 & & & $5 / 2 / 06$ & $5 / 22 / 06$ & WCF147012X & $7440-39-3$ \\
\hline Barium & 299 & MW-2 & & & $5 / 2 / 06$ & $5 / 22 / 06$ & WCF145012X & $7440-39-3$ \\
\hline Barium & 604 & MW-5-2 & & & $5 / 2 / 06$ & $5 / 22 / 06$ & WCF141012X & $7440-39-3$ \\
\hline
\end{tabular}


Table B-1. (continued).

\begin{tabular}{|c|c|c|c|c|c|c|c|c|}
\hline Constituent & $\begin{array}{l}\text { Conc. } \\
(\mu \mathrm{g} / \mathrm{L})\end{array}$ & Location & $\begin{array}{c}\text { Lab } \\
\text { Qualifier }\end{array}$ & $\begin{array}{c}\text { Validation } \\
\text { Qualifier }\end{array}$ & $\begin{array}{c}\text { Date } \\
\text { Collected }\end{array}$ & $\begin{array}{c}\text { Date } \\
\text { Analyzed }\end{array}$ & $\begin{array}{l}\text { Sample } \\
\text { Number }\end{array}$ & $\begin{array}{c}\text { CAS } \\
\text { Number }\end{array}$ \\
\hline Barium & 200 & TFSE-SP & & & $5 / 2 / 06$ & $5 / 22 / 06$ & WCF147022X & $7440-39-3$ \\
\hline Barium & 382 & TFS-SP & & & $5 / 2 / 06$ & $5 / 22 / 06$ & WCF146012X & $7440-39-3$ \\
\hline Benzene & 1 & CPP-33-1 & $\mathrm{U}$ & & $5 / 1 / 06$ & $5 / 9 / 06$ & WCF14401VA & $71-43-2$ \\
\hline Benzene & 1 & CPP-55-06 & $\mathrm{U}$ & & $5 / 1 / 06$ & $5 / 10 / 06$ & WCF14801VA & $71-43-2$ \\
\hline Benzene & 1 & ICPP-2018 & $\mathrm{U}$ & & $5 / 2 / 06$ & $5 / 9 / 06$ & WCF14601VA & $71-43-2$ \\
\hline Benzene & 1 & ICPP-2019 & $\mathrm{U}$ & & $5 / 2 / 06$ & $5 / 10 / 06$ & WCF14702VA & $71-43-2$ \\
\hline Benzene & 1 & MW-10-2 & $\mathrm{U}$ & & $5 / 3 / 06$ & $5 / 10 / 06$ & WCF14901VA & $71-43-2$ \\
\hline Benzene & 1 & MW-10-2 & $\mathrm{U}$ & & $5 / 3 / 06$ & $5 / 10 / 06$ & WCF14902VA & $71-43-2$ \\
\hline Benzene & 1 & MW-2 & $\mathrm{U}$ & & $5 / 2 / 06$ & $5 / 9 / 06$ & WCF14501VA & $71-43-2$ \\
\hline Benzene & 1 & MW-5-2 & $\mathrm{U}$ & & $5 / 2 / 06$ & $5 / 9 / 06$ & WCF14101VA & $71-43-2$ \\
\hline Benzene & 1 & TFSE-SP & $\mathrm{U}$ & & $5 / 2 / 06$ & $5 / 10 / 06$ & WCF14701VA & $71-43-2$ \\
\hline Bromoform & 1 & CPP-33-1 & $\mathrm{U}$ & & $5 / 1 / 06$ & $5 / 9 / 06$ & WCF14401VA & $75-25-2$ \\
\hline Bromoform & 1 & CPP-55-06 & $\mathrm{U}$ & & $5 / 1 / 06$ & $5 / 10 / 06$ & WCF14801VA & $75-25-2$ \\
\hline Bromoform & 1 & ICPP-2018 & $\mathrm{U}$ & & $5 / 2 / 06$ & $5 / 9 / 06$ & WCF14601VA & $75-25-2$ \\
\hline Bromoform & 1 & ICPP-2019 & $\mathrm{U}$ & & $5 / 2 / 06$ & $5 / 10 / 06$ & WCF14702VA & $75-25-2$ \\
\hline Bromoform & 1 & MW-10-2 & $\mathrm{U}$ & & $5 / 3 / 06$ & $5 / 10 / 06$ & WCF14901VA & $75-25-2$ \\
\hline Bromoform & 1 & MW-10-2 & $\mathrm{U}$ & & $5 / 3 / 06$ & $5 / 10 / 06$ & WCF14902VA & $75-25-2$ \\
\hline Bromoform & 1 & MW-2 & $\mathrm{U}$ & & $5 / 2 / 06$ & $5 / 9 / 06$ & WCF14501VA & $75-25-2$ \\
\hline Bromoform & 1 & MW-5-2 & $\mathrm{U}$ & & $5 / 2 / 06$ & $5 / 9 / 06$ & WCF14101VA & $75-25-2$ \\
\hline Bromoform & 1 & TFSE-SP & $\mathrm{U}$ & & $5 / 2 / 06$ & $5 / 10 / 06$ & WCF14701VA & $75-25-2$ \\
\hline Cadmium & 1 & CPP-33-1 & $\mathrm{U}$ & & $5 / 1 / 06$ & $5 / 22 / 06$ & WCF144012X & $7440-43-9$ \\
\hline Cadmium & 1 & CPP-55-06 & $\mathrm{U}$ & & $5 / 1 / 06$ & $5 / 22 / 06$ & WCF148012X & $7440-43-9$ \\
\hline Cadmium & 1 & ICPP-2019 & $\mathrm{U}$ & & $5 / 2 / 06$ & $5 / 22 / 06$ & WCF147012X & $7440-43-9$ \\
\hline Cadmium & 1 & MW-2 & $\mathrm{U}$ & & $5 / 2 / 06$ & $5 / 22 / 06$ & WCF145012X & $7440-43-9$ \\
\hline Cadmium & 1 & MW-5-2 & $\mathrm{U}$ & & $5 / 2 / 06$ & $5 / 22 / 06$ & WCF141012X & $7440-43-9$ \\
\hline Cadmium & 1 & TFSE-SP & $\mathrm{U}$ & & $5 / 2 / 06$ & $5 / 22 / 06$ & WCF147022X & $7440-43-9$ \\
\hline Cadmium & 1 & TFS-SP & $\mathrm{U}$ & & $5 / 2 / 06$ & $5 / 22 / 06$ & WCF146012X & $7440-43-9$ \\
\hline Carbon disulfide & 1 & CPP-33-1 & $\mathrm{U}$ & & $5 / 1 / 06$ & $5 / 9 / 06$ & WCF14401VA & $75-15-0$ \\
\hline Carbon disulfide & 1 & CPP-55-06 & $\mathrm{U}$ & & $5 / 1 / 06$ & $5 / 10 / 06$ & WCF14801VA & $75-15-0$ \\
\hline
\end{tabular}


Table B-1. (continued).

\begin{tabular}{|c|c|c|c|c|c|c|c|c|}
\hline Constituent & $\begin{array}{l}\text { Conc. } \\
(\mu \mathrm{g} / \mathrm{L})\end{array}$ & Location & $\begin{array}{c}\text { Lab } \\
\text { Qualifier }\end{array}$ & $\begin{array}{l}\text { Validation } \\
\text { Qualifier }\end{array}$ & $\begin{array}{c}\text { Date } \\
\text { Collected }\end{array}$ & $\begin{array}{c}\text { Date } \\
\text { Analyzed }\end{array}$ & $\begin{array}{c}\text { Sample } \\
\text { Number }\end{array}$ & $\begin{array}{c}\text { CAS } \\
\text { Number }\end{array}$ \\
\hline Carbon disulfide & 1 & ICPP-2018 & $\mathrm{U}$ & & $5 / 2 / 06$ & $5 / 9 / 06$ & WCF14601VA & $75-15-0$ \\
\hline Carbon disulfide & 1 & ICPP-2019 & $\mathrm{U}$ & & $5 / 2 / 06$ & $5 / 10 / 06$ & WCF14702VA & $75-15-0$ \\
\hline Carbon disulfide & 1 & MW-10-2 & $\mathrm{U}$ & & $5 / 3 / 06$ & $5 / 10 / 06$ & WCF14901VA & $75-15-0$ \\
\hline Carbon disulfide & 1 & MW-10-2 & $\mathrm{U}$ & & $5 / 3 / 06$ & $5 / 10 / 06$ & WCF14902VA & $75-15-0$ \\
\hline Carbon disulfide & 1 & MW-2 & $\mathrm{U}$ & & $5 / 2 / 06$ & $5 / 9 / 06$ & WCF14501VA & $75-15-0$ \\
\hline Carbon disulfide & 1 & MW-5-2 & $\mathrm{U}$ & & $5 / 2 / 06$ & $5 / 9 / 06$ & WCF14101VA & $75-15-0$ \\
\hline Carbon disulfide & 1 & TFSE-SP & $\mathrm{U}$ & & $5 / 2 / 06$ & $5 / 10 / 06$ & WCF14701VA & $75-15-0$ \\
\hline Carbon tetrachloride & 1 & CPP-33-1 & $\mathrm{U}$ & & $5 / 1 / 06$ & $5 / 9 / 06$ & WCF14401VA & $56-23-5$ \\
\hline Carbon tetrachloride & 1 & CPP-55-06 & $\mathrm{U}$ & & $5 / 1 / 06$ & $5 / 10 / 06$ & WCF14801VA & $56-23-5$ \\
\hline Carbon tetrachloride & 1 & ICPP-2018 & $\mathrm{U}$ & & $5 / 2 / 06$ & $5 / 9 / 06$ & WCF14601VA & $56-23-5$ \\
\hline Carbon tetrachloride & 1 & ICPP-2019 & $\mathrm{U}$ & & $5 / 2 / 06$ & $5 / 10 / 06$ & WCF14702VA & $56-23-5$ \\
\hline Carbon tetrachloride & 1 & MW-10-2 & $\mathrm{U}$ & & $5 / 3 / 06$ & $5 / 10 / 06$ & WCF14901VA & $56-23-5$ \\
\hline Carbon tetrachloride & 1 & MW-10-2 & $\mathrm{U}$ & & $5 / 3 / 06$ & $5 / 10 / 06$ & WCF14902VA & $56-23-5$ \\
\hline Carbon tetrachloride & 1 & MW-2 & $\mathrm{U}$ & & $5 / 2 / 06$ & $5 / 9 / 06$ & WCF14501VA & $56-23-5$ \\
\hline Carbon tetrachloride & 1 & MW-5-2 & $\mathrm{U}$ & & $5 / 2 / 06$ & $5 / 9 / 06$ & WCF14101VA & $56-23-5$ \\
\hline Carbon tetrachloride & 1 & TFSE-SP & $\mathrm{U}$ & & $5 / 2 / 06$ & $5 / 10 / 06$ & WCF14701VA & $56-23-5$ \\
\hline Chloroform & 1 & CPP-33-1 & $\mathrm{U}$ & & $5 / 1 / 06$ & $5 / 9 / 06$ & WCF14401VA & $67-66-3$ \\
\hline Chloroform & 1 & CPP-55-06 & $\mathrm{U}$ & & $5 / 1 / 06$ & $5 / 10 / 06$ & WCF14801VA & $67-66-3$ \\
\hline Chloroform & 1 & ICPP-2018 & $\mathrm{U}$ & & $5 / 2 / 06$ & $5 / 9 / 06$ & WCF14601VA & $67-66-3$ \\
\hline Chloroform & 1 & ICPP-2019 & $\mathrm{U}$ & & $5 / 2 / 06$ & $5 / 10 / 06$ & WCF14702VA & $67-66-3$ \\
\hline Chloroform & 1 & MW-10-2 & $\mathrm{U}$ & & $5 / 3 / 06$ & $5 / 10 / 06$ & WCF14901VA & $67-66-3$ \\
\hline Chloroform & 1 & MW-10-2 & $\mathrm{U}$ & & $5 / 3 / 06$ & $5 / 10 / 06$ & WCF14902VA & $67-66-3$ \\
\hline Chloroform & 1 & MW-2 & $\mathrm{U}$ & & $5 / 2 / 06$ & $5 / 9 / 06$ & WCF14501VA & $67-66-3$ \\
\hline Chloroform & 1 & MW-5-2 & $\mathrm{U}$ & & $5 / 2 / 06$ & $5 / 9 / 06$ & WCF14101VA & $67-66-3$ \\
\hline Chloroform & 1 & TFSE-SP & $\mathrm{U}$ & & $5 / 2 / 06$ & $5 / 10 / 06$ & WCF14701VA & $67-66-3$ \\
\hline Chromium & 14 & СРP-33-1 & & & $5 / 1 / 06$ & $5 / 22 / 06$ & WCF144012X & $7440-47-3$ \\
\hline Chromium & 6.6 & CPP-55-06 & $\mathrm{B}$ & & $5 / 1 / 06$ & $5 / 22 / 06$ & WCF148012X & $7440-47-3$ \\
\hline Chromium & 7.2 & ICPP-2019 & $\mathrm{B}$ & & $5 / 2 / 06$ & $5 / 22 / 06$ & WCF147012X & $7440-47-3$ \\
\hline Chromium & 4.4 & MW-2 & $\mathrm{B}$ & & $5 / 2 / 06$ & $5 / 22 / 06$ & WCF145012X & $7440-47-3$ \\
\hline
\end{tabular}


Table B-1. (continued).

\begin{tabular}{|c|c|c|c|c|c|c|c|c|}
\hline Constituent & $\begin{array}{l}\text { Conc. } \\
(\mu \mathrm{g} / \mathrm{L})\end{array}$ & Location & $\begin{array}{c}\text { Lab } \\
\text { Qualifier }\end{array}$ & $\begin{array}{l}\text { Validation } \\
\text { Qualifier }\end{array}$ & $\begin{array}{c}\text { Date } \\
\text { Collected }\end{array}$ & $\begin{array}{c}\text { Date } \\
\text { Analyzed }\end{array}$ & $\begin{array}{c}\text { Sample } \\
\text { Number }\end{array}$ & $\begin{array}{c}\text { CAS } \\
\text { Number }\end{array}$ \\
\hline Chromium & 2.5 & MW-5-2 & $\mathrm{U}$ & & $5 / 2 / 06$ & $5 / 22 / 06$ & WCF141012X & $7440-47-3$ \\
\hline Chromium & 7 & TFSE-SP & $\mathrm{B}$ & & $5 / 2 / 06$ & $5 / 22 / 06$ & WCF147022X & $7440-47-3$ \\
\hline Chromium & 2.5 & TFS-SP & $\mathrm{U}$ & & $5 / 2 / 06$ & $5 / 22 / 06$ & WCF146012X & $7440-47-3$ \\
\hline cis-1,2-Dichloroethene & 1 & CPP-33-1 & $\mathrm{U}$ & & $5 / 1 / 06$ & $5 / 9 / 06$ & WCF14401VA & $156-59-2$ \\
\hline cis-1,2-Dichloroethene & 1 & CPP-55-06 & $\mathrm{U}$ & & $5 / 1 / 06$ & $5 / 10 / 06$ & WCF14801VA & $156-59-2$ \\
\hline cis-1,2-Dichloroethene & 1 & ICPP-2018 & $\mathrm{U}$ & & $5 / 2 / 06$ & $5 / 9 / 06$ & WCF14601VA & $156-59-2$ \\
\hline cis-1,2-Dichloroethene & 1 & ICPP-2019 & $\mathrm{U}$ & & $5 / 2 / 06$ & $5 / 10 / 06$ & WCF14702VA & $156-59-2$ \\
\hline cis-1,2-Dichloroethene & 1 & MW-10-2 & $\mathrm{U}$ & & $5 / 3 / 06$ & $5 / 10 / 06$ & WCF14901VA & $156-59-2$ \\
\hline cis-1,2-Dichloroethene & 1 & MW-10-2 & $\mathrm{U}$ & & $5 / 3 / 06$ & $5 / 10 / 06$ & WCF14902VA & $156-59-2$ \\
\hline cis-1,2-Dichloroethene & 1 & MW-2 & $\mathrm{U}$ & & $5 / 2 / 06$ & $5 / 9 / 06$ & WCF14501VA & $156-59-2$ \\
\hline cis-1,2-Dichloroethene & 1 & MW-5-2 & $\mathrm{U}$ & & $5 / 2 / 06$ & $5 / 9 / 06$ & WCF14101VA & $156-59-2$ \\
\hline cis-1,2-Dichloroethene & 1 & TFSE-SP & $\mathrm{U}$ & & $5 / 2 / 06$ & $5 / 10 / 06$ & WCF14701VA & $156-59-2$ \\
\hline trans-1,2-Dichloroethene & 1 & CPP-33-1 & $\mathrm{U}$ & & $5 / 1 / 06$ & $5 / 9 / 06$ & WCF14401VA & $156-60-5$ \\
\hline trans-1,2-Dichloroethene & 1 & CPP-55-06 & $\mathrm{U}$ & & $5 / 1 / 06$ & $5 / 10 / 06$ & WCF14801VA & $156-60-5$ \\
\hline trans-1,2-Dichloroethene & 1 & ICPP-2018 & $\mathrm{U}$ & & $5 / 2 / 06$ & $5 / 9 / 06$ & WCF14601VA & $156-60-5$ \\
\hline trans-1,2-Dichloroethene & 1 & ICPP-2019 & $\mathrm{U}$ & & $5 / 2 / 06$ & $5 / 10 / 06$ & WCF14702VA & $156-60-5$ \\
\hline trans-1,2-Dichloroethene & 1 & MW-10-2 & $\mathrm{U}$ & & $5 / 3 / 06$ & $5 / 10 / 06$ & WCF14901VA & $156-60-5$ \\
\hline trans-1,2-Dichloroethene & 1 & MW-10-2 & $\mathrm{U}$ & & $5 / 3 / 06$ & $5 / 10 / 06$ & WCF14902VA & $156-60-5$ \\
\hline trans-1,2-Dichloroethene & 1 & MW-2 & $\mathrm{U}$ & & $5 / 2 / 06$ & $5 / 9 / 06$ & WCF14501VA & $156-60-5$ \\
\hline trans-1,2-Dichloroethene & 1 & MW-5-2 & $\mathrm{U}$ & & $5 / 2 / 06$ & $5 / 9 / 06$ & WCF14101VA & $156-60-5$ \\
\hline trans-1,2-Dichloroethene & 1 & TFSE-SP & $\mathrm{U}$ & & $5 / 2 / 06$ & $5 / 10 / 06$ & WCF14701VA & $156-60-5$ \\
\hline 1,4-Dioxane & 2.5 & CPP-33-1 & $\mathrm{U}$ & UJ & $5 / 1 / 06$ & $6 / 7 / 06$ & WCF14401SV & $123-91-1$ \\
\hline 1,4-Dioxane & 2.5 & CPP-55-06 & $\mathrm{U}$ & UJ & $5 / 1 / 06$ & $6 / 7 / 06$ & WCF14801SV & $123-91-1$ \\
\hline 1,4-Dioxane & 2.5 & ICPP-2019 & $\mathrm{U}$ & & $5 / 2 / 06$ & $6 / 7 / 06$ & WCF14701SV & $123-91-1$ \\
\hline 1,4-Dioxane & 3.1 & MW-10-2 & & $\mathrm{J}$ & $5 / 3 / 06$ & $6 / 7 / 06$ & WCF14901SV & $123-91-1$ \\
\hline 1,4-Dioxane & 2.5 & MW-2 & $\mathrm{U}$ & UJ & $5 / 2 / 06$ & $6 / 7 / 06$ & WCF14501SV & 123-91-1 \\
\hline 1,4-Dioxane & 2.5 & MW-5-2 & $\mathrm{U}$ & UJ & $5 / 2 / 06$ & $6 / 7 / 06$ & WCF14101SV & $123-91-1$ \\
\hline 1,4-Dioxane & 2.5 & TFSE-SP & $\mathrm{U}$ & & $5 / 2 / 06$ & $6 / 7 / 06$ & WCF14702SV & $123-91-1$ \\
\hline 1,4-Dioxane & 2.5 & TFS-SP & $\mathrm{U}$ & & $5 / 2 / 06$ & $6 / 7 / 06$ & WCF14601SV & 123-91-1 \\
\hline
\end{tabular}


Table B-1. (continued).

\begin{tabular}{|c|c|c|c|c|c|c|c|c|}
\hline Constituent & $\begin{array}{l}\text { Conc. } \\
(\mu \mathrm{g} / \mathrm{L})\end{array}$ & Location & $\begin{array}{c}\text { Lab } \\
\text { Qualifier }\end{array}$ & $\begin{array}{l}\text { Validation } \\
\text { Qualifier }\end{array}$ & $\begin{array}{c}\text { Date } \\
\text { Collected }\end{array}$ & $\begin{array}{c}\text { Date } \\
\text { Analyzed }\end{array}$ & $\begin{array}{l}\text { Sample } \\
\text { Number }\end{array}$ & $\begin{array}{c}\text { CAS } \\
\text { Number }\end{array}$ \\
\hline Cyanide & 10 & СРP-33-1 & & & $5 / 1 / 06$ & $5 / 15 / 06$ & WCF14401C2 & $57-12-5$ \\
\hline Cyanide & 10 & CPP-55-06 & & & $5 / 1 / 06$ & $5 / 15 / 06$ & WCF14801C2 & $57-12-5$ \\
\hline Cyanide & 10 & ICPP-2019 & & & $5 / 2 / 06$ & $5 / 15 / 06$ & WCF14701C2 & $57-12-5$ \\
\hline Cyanide & 10 & MW-2 & & & $5 / 2 / 06$ & $5 / 15 / 06$ & WCF14501C2 & $57-12-5$ \\
\hline Cyanide & 10 & MW-5-2 & & & $5 / 2 / 06$ & $5 / 15 / 06$ & WCF14101C2 & $57-12-5$ \\
\hline Cyanide & 10 & TFSE-SP & & & $5 / 2 / 06$ & $5 / 15 / 06$ & WCF14702C2 & $57-12-5$ \\
\hline Cyanide & 10 & TFS-SP & & & $5 / 2 / 06$ & $5 / 15 / 06$ & WCF14601C2 & $57-12-5$ \\
\hline Formaldehyde & 232 & CPP-33-1 & $\mathrm{J}$ & $\mathrm{U}$ & $5 / 1 / 06$ & $5 / 6 / 06$ & WCF144012F & $50-00-0$ \\
\hline Formaldehyde & 232 & CPP-55-06 & $\mathrm{J}$ & $\mathrm{U}$ & $5 / 1 / 06$ & $5 / 6 / 06$ & WCF148012F & $50-00-0$ \\
\hline Formaldehyde & 232 & ICPP-2019 & $\mathrm{J}$ & $\mathrm{U}$ & $5 / 2 / 06$ & $5 / 6 / 06$ & WCF147012F & $50-00-0$ \\
\hline Formaldehyde & 232 & MW-10-2 & $\mathrm{J}$ & $\mathrm{U}$ & $5 / 3 / 06$ & $5 / 6 / 06$ & WCF149012F & $50-00-0$ \\
\hline Formaldehyde & 232 & MW-2 & $\mathrm{J}$ & $\mathrm{U}$ & $5 / 2 / 06$ & $5 / 6 / 06$ & WCF145012F & $50-00-0$ \\
\hline Formaldehyde & 232 & MW-5-2 & $\mathrm{J}$ & $\mathrm{U}$ & $5 / 2 / 06$ & $5 / 6 / 06$ & WCF141012F & $50-00-0$ \\
\hline Formaldehyde & 232 & TFSE-SP & $\mathrm{J}$ & $\mathrm{U}$ & $5 / 2 / 06$ & $5 / 6 / 06$ & WCF147022F & $50-00-0$ \\
\hline Formaldehyde & 232 & TFS-SP & $\mathrm{J}$ & $\mathrm{U}$ & $5 / 2 / 06$ & $5 / 6 / 06$ & WCF146012F & $50-00-0$ \\
\hline Hydrazine & 5 & CPP-33-1 & $\mathrm{U}$ & & $5 / 1 / 06$ & $5 / 3 / 06$ & WCF144014H & $302-01-2$ \\
\hline Hydrazine & 5 & CPP-55-06 & $\mathrm{U}$ & & $5 / 1 / 06$ & $5 / 3 / 06$ & WCF148014H & $302-01-2$ \\
\hline Hydrazine & 5 & ICPP-2018 & $\mathrm{U}$ & & $5 / 2 / 06$ & $5 / 3 / 06$ & WCF146014H & $302-01-2$ \\
\hline Hydrazine & 5 & ICPP-2019 & $\mathrm{U}$ & & $5 / 2 / 06$ & $5 / 3 / 06$ & WCF147014H & $302-01-2$ \\
\hline Hydrazine & 5 & MW-10-2 & $\mathrm{U}$ & & $5 / 3 / 06$ & $5 / 5 / 06$ & WCF149014H & $302-01-2$ \\
\hline Hydrazine & 5 & MW-2 & $\mathrm{U}$ & & $5 / 2 / 06$ & $5 / 3 / 06$ & WCF145014H & $302-01-2$ \\
\hline Hydrazine & 5 & MW-5-2 & $\mathrm{U}$ & & $5 / 2 / 06$ & $5 / 3 / 06$ & WCF141014H & $302-01-2$ \\
\hline Hydrazine & 5 & TFSE-SP & $\mathrm{U}$ & & $5 / 2 / 06$ & $5 / 3 / 06$ & WCF147024H & $302-01-2$ \\
\hline Iodomethane & 2 & CPP-33-1 & $\mathrm{U}$ & UJ & $5 / 1 / 06$ & $5 / 9 / 06$ & WCF14401VA & $74-88-4$ \\
\hline Iodomethane & 2 & CPP-55-06 & $\mathrm{U}$ & & $5 / 1 / 06$ & $5 / 10 / 06$ & WCF14801VA & $74-88-4$ \\
\hline Iodomethane & 2 & ICPP-2018 & $\mathrm{U}$ & UJ & $5 / 2 / 06$ & $5 / 9 / 06$ & WCF14601VA & $74-88-4$ \\
\hline Iodomethane & 2 & ICPP-2019 & $\mathrm{U}$ & & $5 / 2 / 06$ & $5 / 10 / 06$ & WCF14702VA & $74-88-4$ \\
\hline Iodomethane & 2 & MW-10-2 & $\mathrm{U}$ & & $5 / 3 / 06$ & $5 / 10 / 06$ & WCF14901VA & $74-88-4$ \\
\hline Iodomethane & 2 & MW-10-2 & $\mathrm{U}$ & & $5 / 3 / 06$ & $5 / 10 / 06$ & WCF14902VA & 74-88-4 \\
\hline
\end{tabular}


Table B-1. (continued).

\begin{tabular}{|c|c|c|c|c|c|c|c|c|}
\hline Constituent & $\begin{array}{l}\text { Conc. } \\
(\mu \mathrm{g} / \mathrm{L})\end{array}$ & Location & $\begin{array}{c}\text { Lab } \\
\text { Qualifier }\end{array}$ & $\begin{array}{l}\text { Validation } \\
\text { Qualifier }\end{array}$ & $\begin{array}{c}\text { Date } \\
\text { Collected }\end{array}$ & $\begin{array}{c}\text { Date } \\
\text { Analyzed }\end{array}$ & $\begin{array}{c}\text { Sample } \\
\text { Number }\end{array}$ & $\begin{array}{c}\text { CAS } \\
\text { Number }\end{array}$ \\
\hline Iodomethane & 2 & MW-2 & U & UJ & $5 / 2 / 06$ & $5 / 9 / 06$ & WCF14501VA & $74-88-4$ \\
\hline Iodomethane & 2 & MW-5-2 & $\mathrm{U}$ & UJ & $5 / 2 / 06$ & $5 / 9 / 06$ & WCF14101VA & $74-88-4$ \\
\hline Iodomethane & 2 & TFSE-SP & $\mathrm{U}$ & & $5 / 2 / 06$ & $5 / 10 / 06$ & WCF14701VA & $74-88-4$ \\
\hline Isobutyl alcohol & 50 & СРP-33-1 & $\mathrm{U}$ & & $5 / 1 / 06$ & $5 / 8 / 06$ & WCF14401TQ & $78-83-1$ \\
\hline Isobutyl alcohol & 50 & CPP-55-06 & $\mathrm{U}$ & & $5 / 1 / 06$ & $5 / 8 / 06$ & WCF14801TQ & $78-83-1$ \\
\hline Isobutyl alcohol & 50 & ICPP-2019 & $\mathrm{U}$ & & $5 / 2 / 06$ & $5 / 8 / 06$ & WCF14701TQ & $78-83-1$ \\
\hline Isobutyl alcohol & 50 & MW-10-2 & $\mathrm{U}$ & & $5 / 3 / 06$ & $5 / 8 / 06$ & WCF14901TQ & $78-83-1$ \\
\hline Isobutyl alcohol & 50 & MW-2 & $\mathrm{U}$ & & $5 / 2 / 06$ & $5 / 8 / 06$ & WCF14501TQ & $78-83-1$ \\
\hline Isobutyl alcohol & 50 & MW-5-2 & $\mathrm{U}$ & & $5 / 2 / 06$ & $5 / 8 / 06$ & WCF14101TQ & $78-83-1$ \\
\hline Isobutyl alcohol & 50 & TFSE-SP & $\mathrm{U}$ & & $5 / 2 / 06$ & $5 / 8 / 06$ & WCF14702TQ & $78-83-1$ \\
\hline Isobutyl alcohol & 50 & TFS-SP & $\mathrm{U}$ & & $5 / 2 / 06$ & $5 / 8 / 06$ & WCF14601TQ & $78-83-1$ \\
\hline Lead & 2.5 & CPP-33-1 & $\mathrm{U}$ & & $5 / 1 / 06$ & $5 / 22 / 06$ & WCF144012X & $7439-92-1$ \\
\hline Lead & 2.5 & CPP-55-06 & $\mathrm{U}$ & & $5 / 1 / 06$ & $5 / 22 / 06$ & WCF148012X & 7439-92-1 \\
\hline Lead & 2.5 & ICPP-2019 & $\mathrm{U}$ & & $5 / 2 / 06$ & $5 / 22 / 06$ & WCF147012X & $7439-92-1$ \\
\hline Lead & 2.5 & MW-2 & $\mathrm{U}$ & & $5 / 2 / 06$ & $5 / 22 / 06$ & WCF145012X & 7439-92-1 \\
\hline Lead & 2.5 & MW-5-2 & $\mathrm{U}$ & & $5 / 2 / 06$ & $5 / 22 / 06$ & WCF141012X & 7439-92-1 \\
\hline Lead & 2.5 & TFSE-SP & $\mathrm{U}$ & & $5 / 2 / 06$ & $5 / 22 / 06$ & WCF147022X & $7439-92-1$ \\
\hline Lead & 2.5 & TFS-SP & $\mathrm{U}$ & & $5 / 2 / 06$ & $5 / 22 / 06$ & WCF146012X & $7439-92-1$ \\
\hline Mercury & 0.2 & CPP-33-1 & $\mathrm{U}$ & & $5 / 1 / 06$ & $5 / 16 / 06$ & WCF144012X & 7439-97-6 \\
\hline Mercury & 0.2 & CPP-55-06 & $\mathrm{U}$ & & $5 / 1 / 06$ & $5 / 16 / 06$ & WCF148012X & $7439-97-6$ \\
\hline Mercury & 0.2 & ICPP-2019 & $\mathrm{U}$ & & $5 / 2 / 06$ & $5 / 16 / 06$ & WCF147012X & 7439-97-6 \\
\hline Mercury & 0.2 & MW-2 & $\mathrm{U}$ & & $5 / 2 / 06$ & $5 / 16 / 06$ & WCF145012X & 7439-97-6 \\
\hline Mercury & 0.2 & MW-5-2 & $\mathrm{U}$ & & $5 / 2 / 06$ & $5 / 16 / 06$ & WCF141012X & $7439-97-6$ \\
\hline Mercury & 0.2 & TFSE-SP & $\mathrm{U}$ & & $5 / 2 / 06$ & $5 / 16 / 06$ & WCF147022X & 7439-97-6 \\
\hline Mercury & 0.2 & TFS-SP & $\mathrm{U}$ & & $5 / 2 / 06$ & $5 / 16 / 06$ & WCF146012X & 7439-97-6 \\
\hline Methylene chloride & 1 & СРP-33-1 & $\mathrm{U}$ & & $5 / 1 / 06$ & $5 / 9 / 06$ & WCF14401VA & $75-09-2$ \\
\hline Methylene chloride & 1 & CPP-55-06 & $\mathrm{U}$ & & $5 / 1 / 06$ & $5 / 10 / 06$ & WCF14801VA & $75-09-2$ \\
\hline Methylene chloride & 1 & ICPP-2018 & $\mathrm{U}$ & & $5 / 2 / 06$ & $5 / 9 / 06$ & WCF14601VA & $75-09-2$ \\
\hline Methylene chloride & 1 & ICPP-2019 & $\mathrm{U}$ & & $5 / 2 / 06$ & $5 / 10 / 06$ & WCF14702VA & $75-09-2$ \\
\hline
\end{tabular}


Table B-1. (continued).

\begin{tabular}{|c|c|c|c|c|c|c|c|c|}
\hline Constituent & $\begin{array}{l}\text { Conc. } \\
(\mu \mathrm{g} / \mathrm{L})\end{array}$ & Location & $\begin{array}{c}\text { Lab } \\
\text { Qualifier }\end{array}$ & $\begin{array}{l}\text { Validation } \\
\text { Qualifier }\end{array}$ & $\begin{array}{c}\text { Date } \\
\text { Collected }\end{array}$ & $\begin{array}{c}\text { Date } \\
\text { Analyzed }\end{array}$ & $\begin{array}{c}\text { Sample } \\
\text { Number }\end{array}$ & $\begin{array}{c}\text { CAS } \\
\text { Number }\end{array}$ \\
\hline Methylene chloride & 1 & MW-10-2 & $\mathrm{U}$ & & $5 / 3 / 06$ & $5 / 10 / 06$ & WCF14901VA & $75-09-2$ \\
\hline Methylene chloride & 1 & MW-10-2 & $\mathrm{U}$ & & $5 / 3 / 06$ & $5 / 10 / 06$ & WCF14902VA & $75-09-2$ \\
\hline Methylene chloride & 1 & MW-2 & $\mathrm{U}$ & & $5 / 2 / 06$ & $5 / 9 / 06$ & WCF14501VA & $75-09-2$ \\
\hline Methylene chloride & 1 & MW-5-2 & $\mathrm{U}$ & & $5 / 2 / 06$ & $5 / 9 / 06$ & WCF14101VA & $75-09-2$ \\
\hline Methylene chloride & 1 & TFSE-SP & $\mathrm{U}$ & & $5 / 2 / 06$ & $5 / 10 / 06$ & WCF14701VA & $75-09-2$ \\
\hline Methyl ethyl ketone & 1 & CPP-33-1 & $\mathrm{U}$ & & $5 / 1 / 06$ & $5 / 9 / 06$ & WCF14401VA & 78-93-3 \\
\hline Methyl ethyl ketone & 1 & CPP-55-06 & $\mathrm{U}$ & & $5 / 1 / 06$ & $5 / 10 / 06$ & WCF14801VA & 78-93-3 \\
\hline Methyl ethyl ketone & 1 & ICPP-2018 & $\mathrm{U}$ & & $5 / 2 / 06$ & $5 / 9 / 06$ & WCF14601VA & $78-93-3$ \\
\hline Methyl ethyl ketone & 1 & ICPP-2019 & $\mathrm{U}$ & & $5 / 2 / 06$ & $5 / 10 / 06$ & WCF14702VA & 78-93-3 \\
\hline Methyl ethyl ketone & 1 & MW-10-2 & $\mathrm{U}$ & & $5 / 3 / 06$ & $5 / 10 / 06$ & WCF14901VA & $78-93-3$ \\
\hline Methyl ethyl ketone & 1 & MW-10-2 & $\mathrm{U}$ & & $5 / 3 / 06$ & $5 / 10 / 06$ & WCF14902VA & $78-93-3$ \\
\hline Methyl ethyl ketone & 1 & MW-2 & $\mathrm{U}$ & & $5 / 2 / 06$ & $5 / 9 / 06$ & WCF14501VA & $78-93-3$ \\
\hline Methyl ethyl ketone & 1 & MW-5-2 & $\mathrm{U}$ & & $5 / 2 / 06$ & $5 / 9 / 06$ & WCF14101VA & $78-93-3$ \\
\hline Methyl ethyl ketone & 1 & TFSE-SP & $\mathrm{U}$ & & $5 / 2 / 06$ & $5 / 10 / 06$ & WCF14701VA & $78-93-3$ \\
\hline Phenol & 2.5 & CPP-33-1 & $\mathrm{U}$ & & $5 / 1 / 06$ & $6 / 1 / 06$ & WCF14401V9 & $108-95-2$ \\
\hline Phenol & 2.5 & CPP-55-06 & $\mathrm{U}$ & & $5 / 1 / 06$ & $6 / 1 / 06$ & WCF14801V9 & $108-95-2$ \\
\hline Phenol & 2.5 & ICPP-2018 & $\mathrm{U}$ & & $5 / 2 / 06$ & $6 / 1 / 06$ & WCF14601V9 & $108-95-2$ \\
\hline Phenol & 2.5 & ICPP-2019 & $\mathrm{U}$ & & $5 / 2 / 06$ & $6 / 1 / 06$ & WCF14701V9 & $108-95-2$ \\
\hline Phenol & 2.5 & ICPP-2019 & $\mathrm{U}$ & & $5 / 2 / 06$ & $6 / 2 / 06$ & WCF14702V9(1) & $108-95-2$ \\
\hline Phenol & 2.5 & MW-10-2 & $\mathrm{U}$ & & $5 / 3 / 06$ & $6 / 2 / 06$ & WCF14901V9 & $108-95-2$ \\
\hline Phenol & 2.5 & MW-2 & $\mathrm{U}$ & & $5 / 2 / 06$ & $6 / 2 / 06$ & WCF14501V9(1) & $108-95-2$ \\
\hline Phenol & 2.5 & MW-5-2 & $\mathrm{U}$ & & $5 / 2 / 06$ & $6 / 1 / 06$ & WCF14101V9 & $108-95-2$ \\
\hline Pyridine & 2.5 & CPP-33-1 & $\mathrm{U}$ & $\mathrm{R}$ & $5 / 1 / 06$ & $6 / 1 / 06$ & WCF14401V9 & $110-86-1$ \\
\hline Pyridine & 2.5 & CPP-55-06 & $\mathrm{U}$ & $\mathrm{R}$ & $5 / 1 / 06$ & $6 / 1 / 06$ & WCF14801V9 & $110-86-1$ \\
\hline Pyridine & 2.5 & ICPP-2018 & $\mathrm{U}$ & $\mathrm{R}$ & $5 / 2 / 06$ & $6 / 1 / 06$ & WCF14601V9 & $110-86-1$ \\
\hline Pyridine & 2.5 & ICPP-2019 & $\mathrm{U}$ & $\mathrm{R}$ & $5 / 2 / 06$ & $6 / 1 / 06$ & WCF14701V9 & $110-86-1$ \\
\hline Pyridine & 2.5 & ICPP-2019 & $\mathrm{U}$ & $\mathrm{R}$ & $5 / 2 / 06$ & $6 / 2 / 06$ & WCF14702V9(1) & $110-86-1$ \\
\hline Pyridine & 2.5 & MW-10-2 & $\mathrm{U}$ & $\mathrm{R}$ & $5 / 3 / 06$ & $6 / 2 / 06$ & WCF14901V9 & $110-86-1$ \\
\hline Pyridine & 2.5 & MW-2 & $\mathrm{U}$ & $\mathrm{R}$ & $5 / 2 / 06$ & $6 / 2 / 06$ & WCF14501V9(1) & $110-86-1$ \\
\hline
\end{tabular}


Table B-1. (continued).

\begin{tabular}{|c|c|c|c|c|c|c|c|c|}
\hline Constituent & $\begin{array}{l}\text { Conc. } \\
(\mu \mathrm{g} / \mathrm{L})\end{array}$ & Location & $\begin{array}{c}\text { Lab } \\
\text { Qualifier }\end{array}$ & $\begin{array}{l}\text { Validation } \\
\text { Qualifier }\end{array}$ & $\begin{array}{c}\text { Date } \\
\text { Collected }\end{array}$ & $\begin{array}{c}\text { Date } \\
\text { Analyzed }\end{array}$ & $\begin{array}{c}\text { Sample } \\
\text { Number }\end{array}$ & $\begin{array}{c}\text { CAS } \\
\text { Number }\end{array}$ \\
\hline Pyridine & 2.5 & MW-5-2 & $\mathrm{U}$ & $\mathrm{R}$ & $5 / 2 / 06$ & $6 / 1 / 06$ & WCF14101V9 & $110-86-1$ \\
\hline Selenium & 4.6 & СРP-33-1 & $\mathrm{B}$ & & $5 / 1 / 06$ & $5 / 22 / 06$ & WCF144012X & $7782-49-2$ \\
\hline Selenium & 2.5 & CPP-55-06 & $\mathrm{U}$ & & $5 / 1 / 06$ & $5 / 22 / 06$ & WCF148012X & $7782-49-2$ \\
\hline Selenium & 2.5 & ICPP-2019 & $\mathrm{U}$ & & $5 / 2 / 06$ & $5 / 22 / 06$ & WCF147012X & $7782-49-2$ \\
\hline Selenium & 2.5 & MW-2 & $\mathrm{U}$ & & $5 / 2 / 06$ & $5 / 22 / 06$ & WCF145012X & $7782-49-2$ \\
\hline Selenium & 2.5 & MW-5-2 & $\mathrm{U}$ & & $5 / 2 / 06$ & $5 / 22 / 06$ & WCF141012X & $7782-49-2$ \\
\hline Selenium & 2.5 & TFSE-SP & $\mathrm{U}$ & & $5 / 2 / 06$ & $5 / 22 / 06$ & WCF147022X & $7782-49-2$ \\
\hline Selenium & 2.5 & TFS-SP & $\mathrm{U}$ & & $5 / 2 / 06$ & $5 / 22 / 06$ & WCF146012X & $7782-49-2$ \\
\hline Silver & 2.5 & CPP-33-1 & $\mathrm{U}$ & & $5 / 1 / 06$ & $5 / 22 / 06$ & WCF144012X & $7440-22-4$ \\
\hline Silver & 2.5 & CPP-55-06 & $\mathrm{U}$ & & $5 / 1 / 06$ & $5 / 22 / 06$ & WCF148012X & $7440-22-4$ \\
\hline Silver & 2.5 & ICPP-2019 & $\mathrm{U}$ & & $5 / 2 / 06$ & $5 / 22 / 06$ & WCF147012X & $7440-22-4$ \\
\hline Silver & 2.5 & MW-2 & $\mathrm{U}$ & & $5 / 2 / 06$ & $5 / 22 / 06$ & WCF145012X & $7440-22-4$ \\
\hline Silver & 2.5 & MW-5-2 & $\mathrm{U}$ & & $5 / 2 / 06$ & $5 / 22 / 06$ & WCF141012X & $7440-22-4$ \\
\hline Silver & 2.5 & TFSE-SP & $\mathrm{U}$ & & $5 / 2 / 06$ & $5 / 22 / 06$ & WCF147022X & $7440-22-4$ \\
\hline Silver & 2.5 & TFS-SP & $\mathrm{U}$ & & $5 / 2 / 06$ & $5 / 22 / 06$ & WCF146012X & $7440-22-4$ \\
\hline Tetrachloroethene & 1 & CPP-33-1 & $\mathrm{U}$ & & $5 / 1 / 06$ & $5 / 9 / 06$ & WCF14401VA & $127-18-4$ \\
\hline Tetrachloroethene & 1 & CPP-55-06 & $\mathrm{U}$ & & $5 / 1 / 06$ & $5 / 10 / 06$ & WCF14801VA & $127-18-4$ \\
\hline Tetrachloroethene & 1 & ICPP-2018 & $\mathrm{U}$ & & $5 / 2 / 06$ & $5 / 9 / 06$ & WCF14601VA & $127-18-4$ \\
\hline Tetrachloroethene & 1 & ICPP-2019 & $\mathrm{U}$ & & $5 / 2 / 06$ & $5 / 10 / 06$ & WCF14702VA & $127-18-4$ \\
\hline Tetrachloroethene & 2.8 & MW-10-2 & & & $5 / 3 / 06$ & $5 / 10 / 06$ & WCF14901VA & $127-18-4$ \\
\hline Tetrachloroethene & 3.4 & MW-10-2 & & & $5 / 3 / 06$ & $5 / 10 / 06$ & WCF14902VA & $127-18-4$ \\
\hline Tetrachloroethene & 1 & MW-2 & $\mathrm{U}$ & & $5 / 2 / 06$ & $5 / 9 / 06$ & WCF14501VA & $127-18-4$ \\
\hline Tetrachloroethene & 1 & MW-5-2 & $\mathrm{U}$ & & $5 / 2 / 06$ & $5 / 9 / 06$ & WCF14101VA & $127-18-4$ \\
\hline Tetrachloroethene & 1 & TFSE-SP & $\mathrm{U}$ & & $5 / 2 / 06$ & $5 / 10 / 06$ & WCF14701VA & $127-18-4$ \\
\hline Toluene & 1 & CPP-33-1 & $\mathrm{U}$ & & $5 / 1 / 06$ & $5 / 9 / 06$ & WCF14401VA & $108-88-3$ \\
\hline Toluene & 1 & CPP-55-06 & $\mathrm{U}$ & & $5 / 1 / 06$ & $5 / 10 / 06$ & WCF14801VA & $108-88-3$ \\
\hline Toluene & 1 & ICPP-2018 & $\mathrm{U}$ & & $5 / 2 / 06$ & $5 / 9 / 06$ & WCF14601VA & $108-88-3$ \\
\hline Toluene & 1 & ICPP-2019 & $\mathrm{U}$ & & $5 / 2 / 06$ & $5 / 10 / 06$ & WCF14702VA & $108-88-3$ \\
\hline Toluene & 5.4 & MW-10-2 & & & $5 / 3 / 06$ & $5 / 10 / 06$ & WCF14901VA & $108-88-3$ \\
\hline
\end{tabular}


Table B-1. (continued).

\begin{tabular}{|c|c|c|c|c|c|c|c|c|}
\hline Constituent & $\begin{array}{l}\text { Conc. } \\
(\mu \mathrm{g} / \mathrm{L})\end{array}$ & Location & $\begin{array}{c}\text { Lab } \\
\text { Qualifier }\end{array}$ & $\begin{array}{l}\text { Validation } \\
\text { Qualifier }\end{array}$ & $\begin{array}{c}\text { Date } \\
\text { Collected }\end{array}$ & $\begin{array}{c}\text { Date } \\
\text { Analyzed }\end{array}$ & $\begin{array}{c}\text { Sample } \\
\text { Number }\end{array}$ & $\begin{array}{c}\text { CAS } \\
\text { Number }\end{array}$ \\
\hline Toluene & 6.4 & MW-10-2 & & & $5 / 3 / 06$ & $5 / 10 / 06$ & WCF14902VA & $108-88-3$ \\
\hline Toluene & 1 & MW-2 & $\mathrm{U}$ & & $5 / 2 / 06$ & $5 / 9 / 06$ & WCF14501VA & $108-88-3$ \\
\hline Toluene & 1 & MW-5-2 & $\mathrm{U}$ & & $5 / 2 / 06$ & $5 / 9 / 06$ & WCF14101VA & $108-88-3$ \\
\hline Toluene & 1 & TFSE-SP & $\mathrm{U}$ & & $5 / 2 / 06$ & $5 / 10 / 06$ & WCF14701VA & $108-88-3$ \\
\hline 1,1,1-Trichloroethane & 1 & CPP-33-1 & $\mathrm{U}$ & UJ & $5 / 1 / 06$ & $5 / 9 / 06$ & WCF14401VA & $71-55-6$ \\
\hline 1,1,1-Trichloroethane & 1 & CPP-55-06 & $\mathrm{U}$ & & $5 / 1 / 06$ & $5 / 10 / 06$ & WCF14801VA & $71-55-6$ \\
\hline 1,1,1-Trichloroethane & 1 & ICPP-2018 & $\mathrm{U}$ & UJ & $5 / 2 / 06$ & $5 / 9 / 06$ & WCF14601VA & $71-55-6$ \\
\hline 1,1,1-Trichloroethane & 1 & ICPP-2019 & $\mathrm{U}$ & & $5 / 2 / 06$ & $5 / 10 / 06$ & WCF14702VA & $71-55-6$ \\
\hline 1,1,1-Trichloroethane & 1 & MW-10-2 & $\mathrm{U}$ & & $5 / 3 / 06$ & $5 / 10 / 06$ & WCF14901VA & $71-55-6$ \\
\hline 1,1,1-Trichloroethane & 1 & MW-10-2 & $\mathrm{U}$ & & $5 / 3 / 06$ & $5 / 10 / 06$ & WCF14902VA & $71-55-6$ \\
\hline 1,1,1-Trichloroethane & 1 & MW-2 & $\mathrm{U}$ & UJ & $5 / 2 / 06$ & $5 / 9 / 06$ & WCF14501VA & $71-55-6$ \\
\hline 1,1,1-Trichloroethane & 1 & MW-5-2 & $\mathrm{U}$ & UJ & $5 / 2 / 06$ & $5 / 9 / 06$ & WCF14101VA & $71-55-6$ \\
\hline 1,1,1-Trichloroethane & 1 & TFSE-SP & $\mathrm{U}$ & & $5 / 2 / 06$ & $5 / 10 / 06$ & WCF14701VA & $71-55-6$ \\
\hline 1,1,2-Trichloroethane & 1 & CPP-33-1 & $\mathrm{U}$ & & $5 / 1 / 06$ & $5 / 9 / 06$ & WCF14401VA & $79-00-5$ \\
\hline 1,1,2-Trichloroethane & 1 & CPP-55-06 & $\mathrm{U}$ & & $5 / 1 / 06$ & $5 / 10 / 06$ & WCF14801VA & $79-00-5$ \\
\hline 1,1,2-Trichloroethane & 1 & ICPP-2018 & $\mathrm{U}$ & & $5 / 2 / 06$ & $5 / 9 / 06$ & WCF14601VA & $79-00-5$ \\
\hline 1,1,2-Trichloroethane & 1 & ICPP-2019 & $\mathrm{U}$ & & $5 / 2 / 06$ & $5 / 10 / 06$ & WCF14702VA & $79-00-5$ \\
\hline 1,1,2-Trichloroethane & 1 & MW-10-2 & $\mathrm{U}$ & & $5 / 3 / 06$ & $5 / 10 / 06$ & WCF14901VA & $79-00-5$ \\
\hline 1,1,2-Trichloroethane & 1 & MW-10-2 & $\mathrm{U}$ & & $5 / 3 / 06$ & $5 / 10 / 06$ & WCF14902VA & $79-00-5$ \\
\hline 1,1,2-Trichloroethane & 1 & MW-2 & $\mathrm{U}$ & & $5 / 2 / 06$ & $5 / 9 / 06$ & WCF14501VA & $79-00-5$ \\
\hline 1,1,2-Trichloroethane & 1 & MW-5-2 & $\mathrm{U}$ & & $5 / 2 / 06$ & $5 / 9 / 06$ & WCF14101VA & $79-00-5$ \\
\hline 1,1,2-Trichloroethane & 1 & TFSE-SP & $\mathrm{U}$ & & $5 / 2 / 06$ & $5 / 10 / 06$ & WCF14701VA & $79-00-5$ \\
\hline Trichloroethene & 1 & CPP-33-1 & $\mathrm{U}$ & & $5 / 1 / 06$ & $5 / 9 / 06$ & WCF14401VA & 79-01-6 \\
\hline Trichloroethene & 1 & CPP-55-06 & $\mathrm{U}$ & & $5 / 1 / 06$ & $5 / 10 / 06$ & WCF14801VA & $79-01-6$ \\
\hline Trichloroethene & 1 & ICPP-2018 & $\mathrm{U}$ & & $5 / 2 / 06$ & $5 / 9 / 06$ & WCF14601VA & $79-01-6$ \\
\hline Trichloroethene & 1 & ICPP-2019 & $\mathrm{U}$ & & $5 / 2 / 06$ & $5 / 10 / 06$ & WCF14702VA & $79-01-6$ \\
\hline Trichloroethene & 1 & MW-10-2 & $\mathrm{U}$ & & $5 / 3 / 06$ & $5 / 10 / 06$ & WCF14901VA & 79-01-6 \\
\hline Trichloroethene & 1 & MW-10-2 & $\mathrm{U}$ & & $5 / 3 / 06$ & $5 / 10 / 06$ & WCF14902VA & 79-01-6 \\
\hline Trichloroethene & 1 & MW-2 & $\mathrm{U}$ & & $5 / 2 / 06$ & $5 / 9 / 06$ & WCF14501VA & $79-01-6$ \\
\hline
\end{tabular}


Table B-1. (continued).

\begin{tabular}{|l|c|l|l|l|l|l|l|l|}
\hline \multicolumn{1}{|c|}{ Constituent } & $\begin{array}{c}\text { Conc. } \\
(\mu \mathrm{g} / \mathrm{L})\end{array}$ & \multicolumn{1}{|c|}{ Location } & $\begin{array}{c}\text { Lab } \\
\text { Qualifier }\end{array}$ & $\begin{array}{c}\text { Validation } \\
\text { Qualifier }\end{array}$ & $\begin{array}{c}\text { Date } \\
\text { Collected }\end{array}$ & $\begin{array}{c}\text { Date } \\
\text { Analyzed }\end{array}$ & $\begin{array}{c}\text { Sample } \\
\text { Number }\end{array}$ & $\begin{array}{c}\text { CAS } \\
\text { Number }\end{array}$ \\
\hline Trichloroethene & 1 & MW-5-2 & $\mathrm{U}$ & & $5 / 2 / 06$ & $5 / 9 / 06$ & WCF14101VA & $79-01-6$ \\
\hline Trichloroethene & 1 & TFSE-SP & $\mathrm{U}$ & & $5 / 2 / 06$ & $5 / 10 / 06$ & WCF14701VA & $79-01-6$ \\
\hline Vanadium & 3.3 & CPP-33-1 & $\mathrm{B}$ & & $5 / 1 / 06$ & $5 / 22 / 06$ & WCF144012X & $7440-62-2$ \\
\hline Vanadium & 2.5 & CPP-55-06 & $\mathrm{U}$ & & $5 / 1 / 06$ & $5 / 22 / 06$ & WCF148012X & $7440-62-2$ \\
\hline Vanadium & 2.5 & ICPP-2019 & $\mathrm{U}$ & & $5 / 2 / 06$ & $5 / 22 / 06$ & WCF147012X & $7440-62-2$ \\
\hline Vanadium & 3.1 & MW-2 & $\mathrm{B}$ & & $5 / 2 / 06$ & $5 / 22 / 06$ & WCF145012X & $7440-62-2$ \\
\hline Vanadium & 2.5 & MW-5-2 & $\mathrm{U}$ & & $5 / 2 / 06$ & $5 / 22 / 06$ & WCF141012X & $7440-62-2$ \\
\hline Vanadium & 2.5 & TFSE-SP & $\mathrm{U}$ & & $5 / 2 / 06$ & $5 / 22 / 06$ & WCF147022X & $7440-62-2$ \\
\hline Vanadium & 2.5 & TFS-SP & $\mathrm{U}$ & & $5 / 2 / 06$ & $5 / 22 / 06$ & WCF146012X & $7440-62-2$ \\
\hline Vinyl chloride & 1 & CPP-33-1 & $\mathrm{U}$ & & $5 / 1 / 06$ & $5 / 9 / 06$ & WCF14401VA & $75-01-4$ \\
\hline Vinyl chloride & 1 & CPP-55-06 & $\mathrm{U}$ & & $5 / 1 / 06$ & $5 / 10 / 06$ & WCF14801VA & $75-01-4$ \\
\hline Vinyl chloride & 1 & ICPP-2018 & $\mathrm{U}$ & & $5 / 2 / 06$ & $5 / 9 / 06$ & WCF14601VA & $75-01-4$ \\
\hline Vinyl chloride & 1 & ICPP-2019 & $\mathrm{U}$ & & $5 / 2 / 06$ & $5 / 10 / 06$ & WCF14702VA & $75-01-4$ \\
\hline Vinyl chloride & 1 & MW-10-2 & $\mathrm{U}$ & & $5 / 3 / 06$ & $5 / 10 / 06$ & WCF14901VA & $75-01-4$ \\
\hline Vinyl chloride & 1 & MW-10-2 & $\mathrm{U}$ & & $5 / 3 / 06$ & $5 / 10 / 06$ & WCF14902VA & $75-01-4$ \\
\hline Vinyl chloride & 1 & MW-2 & $\mathrm{U}$ & & $5 / 2 / 06$ & $5 / 9 / 06$ & WCF14501VA & $75-01-4$ \\
\hline Vinyl chloride & 1 & MW-5-2 & $\mathrm{U}$ & & $5 / 2 / 06$ & $5 / 9 / 06$ & WCF14101VA & $75-01-4$ \\
\hline Vinyl chloride & 1 & TFSE-SP & $\mathrm{U}$ & & $5 / 2 / 06$ & $5 / 10 / 06$ & WCF14701VA & $75-01-4$ \\
\hline
\end{tabular}


Table B-2. WCF analytical results from July 31-August 2, 2006, (12th quarter) sampling event. (See Table B-3 for qualifier and flag definitions.)

\begin{tabular}{|c|c|c|c|c|c|c|c|c|}
\hline Constituent & $\begin{array}{l}\text { Conc. } \\
(\mu \mathrm{g} / \mathrm{L})\end{array}$ & Location & $\begin{array}{c}\text { Lab } \\
\text { Qualifier }\end{array}$ & $\begin{array}{c}\text { Validation } \\
\text { Qualifier }\end{array}$ & $\begin{array}{c}\text { Date } \\
\text { Collected } \\
\end{array}$ & $\begin{array}{c}\text { Date } \\
\text { Analyzed }\end{array}$ & Sample Number & $\begin{array}{c}\text { CAS } \\
\text { Number } \\
\end{array}$ \\
\hline Aniline & 2.4 & CPP-33-1 & $\mathrm{U}$ & $\mathrm{R}$ & $7 / 31 / 06$ & $8 / 18 / 06$ & WCF15901V9 & $62-53-3$ \\
\hline Aniline & 2.4 & CPP-55-06 & $\mathrm{U}$ & $\mathrm{R}$ & $7 / 31 / 06$ & $8 / 18 / 06$ & WCF16301V9 & $62-53-3$ \\
\hline Aniline & 2.5 & ICPP-2018 & $\mathrm{U}$ & $\mathrm{R}$ & $8 / 2 / 06$ & $8 / 18 / 06$ & WCF16101V9 & $62-53-3$ \\
\hline Aniline & 2.4 & ICPP-2019 & $\mathrm{U}$ & $\mathrm{R}$ & $8 / 2 / 06$ & $8 / 18 / 06$ & WCF16201V9 & $62-53-3$ \\
\hline Aniline & 2.4 & ICPP-2019 & $\mathrm{U}$ & $\mathrm{R}$ & $8 / 2 / 06$ & $8 / 18 / 06$ & WCF16202V9 & $62-53-3$ \\
\hline Aniline & 2.5 & MW-2 & $\mathrm{U}$ & $\mathrm{R}$ & $8 / 1 / 06$ & $8 / 18 / 06$ & WCF16001V9 & $62-53-3$ \\
\hline Aniline & 2.7 & MW-5-2 & $\mathrm{U}$ & $\mathrm{R}$ & $8 / 1 / 06$ & $8 / 18 / 06$ & WCF15601V9 & $62-53-3$ \\
\hline Arsenic & 5 & CPP-33-1 & $\mathrm{U}$ & & $7 / 31 / 06$ & $8 / 23 / 06$ & WCF159012X & $7440-38-2$ \\
\hline Arsenic & 5 & CPP-55-06 & $\mathrm{U}$ & & $7 / 31 / 06$ & $8 / 23 / 06$ & WCF163012X & $7440-38-2$ \\
\hline Arsenic & 5 & ICPP-2018 & $\mathrm{U}$ & & $8 / 2 / 06$ & $8 / 23 / 06$ & WCF161012X & $7440-38-2$ \\
\hline Arsenic & 5 & ICPP-2019 & $\mathrm{U}$ & & $8 / 2 / 06$ & $8 / 23 / 06$ & WCF162012X & $7440-38-2$ \\
\hline Arsenic & 5 & ICPP-2019 & $\mathrm{U}$ & & $8 / 2 / 06$ & $8 / 23 / 06$ & WCF162022X & $7440-38-2$ \\
\hline Arsenic & 5 & MW-10-2 & $\mathrm{U}$ & & $8 / 1 / 06$ & $8 / 23 / 06$ & WCF164012X & $7440-38-2$ \\
\hline Arsenic & 5 & MW-2 & $\mathrm{U}$ & & $8 / 1 / 06$ & $8 / 23 / 06$ & WCF160012X & $7440-38-2$ \\
\hline Barium & 133 & CPP-33-1 & & & $7 / 31 / 06$ & $8 / 23 / 06$ & WCF159012X & $7440-39-3$ \\
\hline Barium & 251 & CPP-55-06 & & & $7 / 31 / 06$ & $8 / 23 / 06$ & WCF163012X & $7440-39-3$ \\
\hline Barium & 388 & ICPP-2018 & & & $8 / 2 / 06$ & $8 / 23 / 06$ & WCF161012X & 7440-39-3 \\
\hline Barium & 195 & ICPP-2019 & & & $8 / 2 / 06$ & $8 / 23 / 06$ & WCF162012X & $7440-39-3$ \\
\hline Barium & 194 & ICPP-2019 & & & $8 / 2 / 06$ & $8 / 23 / 06$ & WCF162022X & $7440-39-3$ \\
\hline Barium & 249 & MW-10-2 & & & $8 / 1 / 06$ & $8 / 23 / 06$ & WCF164012X & $7440-39-3$ \\
\hline Barium & 292 & MW-2 & & & $8 / 1 / 06$ & $8 / 23 / 06$ & WCF160012X & 7440-39-3 \\
\hline Benzene & 1 & CPP-33-1 & $\mathrm{U}$ & & $7 / 31 / 06$ & $8 / 10 / 06$ & WCF15901VA & $71-43-2$ \\
\hline Benzene & 1 & CPP-55-06 & $\mathrm{U}$ & & $7 / 31 / 06$ & $8 / 10 / 06$ & WCF16301VA & $71-43-2$ \\
\hline Benzene & 1 & ICPP-2018 & $\mathrm{U}$ & & $8 / 2 / 06$ & $8 / 10 / 06$ & WCF16101VA & $71-43-2$ \\
\hline Benzene & 1 & ICPP-2019 & $\mathrm{U}$ & & $8 / 2 / 06$ & $8 / 10 / 06$ & WCF16201VA & $71-43-2$ \\
\hline Benzene & 1 & ICPP-2019 & $\mathrm{U}$ & & $8 / 2 / 06$ & $8 / 10 / 06$ & WCF16202VA & $71-43-2$ \\
\hline Benzene & 1 & MW-10-2 & $\mathrm{U}$ & & $8 / 1 / 06$ & $8 / 10 / 06$ & WCF16401VA & $71-43-2$ \\
\hline
\end{tabular}


Table B-2. (continued).

\begin{tabular}{|c|c|c|c|c|c|c|c|c|}
\hline Constituent & $\begin{array}{l}\text { Conc. } \\
(\mu \mathrm{g} / \mathrm{L})\end{array}$ & Location & $\begin{array}{c}\text { Lab } \\
\text { Qualifier }\end{array}$ & $\begin{array}{c}\text { Validation } \\
\text { Qualifier }\end{array}$ & $\begin{array}{c}\text { Date } \\
\text { Collected } \\
\end{array}$ & $\begin{array}{c}\text { Date } \\
\text { Analyzed }\end{array}$ & Sample Number & $\begin{array}{c}\text { CAS } \\
\text { Number }\end{array}$ \\
\hline Benzene & 1 & MW-2 & $\mathrm{U}$ & & $8 / 1 / 06$ & $8 / 11 / 06$ & WCF16001VA & $71-43-2$ \\
\hline Benzene & 1 & MW-5-2 & $\mathrm{U}$ & & $8 / 1 / 06$ & $8 / 10 / 06$ & WCF15601VA & $71-43-2$ \\
\hline Bromoform & 1 & СРP-33-1 & $\mathrm{U}$ & & $7 / 31 / 06$ & $8 / 10 / 06$ & WCF15901VA & $75-25-2$ \\
\hline Bromoform & 1 & CPP-55-06 & $\mathrm{U}$ & & $7 / 31 / 06$ & $8 / 10 / 06$ & WCF16301VA & $75-25-2$ \\
\hline Bromoform & 1 & ICPP-2018 & $\mathrm{U}$ & & $8 / 2 / 06$ & $8 / 10 / 06$ & WCF16101VA & $75-25-2$ \\
\hline Bromoform & 1 & ICPP-2019 & $\mathrm{U}$ & & $8 / 2 / 06$ & $8 / 10 / 06$ & WCF16201VA & $75-25-2$ \\
\hline Bromoform & 1 & ICPP-2019 & $\mathrm{U}$ & & $8 / 2 / 06$ & $8 / 10 / 06$ & WCF16202VA & $75-25-2$ \\
\hline Bromoform & 1 & MW-10-2 & $\mathrm{U}$ & & $8 / 1 / 06$ & $8 / 10 / 06$ & WCF16401VA & $75-25-2$ \\
\hline Bromoform & 1 & MW-2 & $\mathrm{U}$ & & $8 / 1 / 06$ & $8 / 11 / 06$ & WCF16001VA & $75-25-2$ \\
\hline Bromoform & 1 & MW-5-2 & $\mathrm{U}$ & & $8 / 1 / 06$ & $8 / 10 / 06$ & WCF15601VA & $75-25-2$ \\
\hline Cadmium & 1 & CPP-33-1 & $\mathrm{U}$ & & $7 / 31 / 06$ & $8 / 23 / 06$ & WCF159012X & $7440-43-9$ \\
\hline Cadmium & 1 & CPP-55-06 & $\mathrm{U}$ & & $7 / 31 / 06$ & $8 / 23 / 06$ & WCF163012X & $7440-43-9$ \\
\hline Cadmium & 1 & ICPP-2018 & $\mathrm{U}$ & & $8 / 2 / 06$ & $8 / 23 / 06$ & WCF161012X & $7440-43-9$ \\
\hline Cadmium & 1 & ICPP-2019 & $\mathrm{U}$ & & $8 / 2 / 06$ & $8 / 23 / 06$ & WCF162012X & $7440-43-9$ \\
\hline Cadmium & 1 & ICPP-2019 & $\mathrm{U}$ & & $8 / 2 / 06$ & $8 / 23 / 06$ & WCF162022X & $7440-43-9$ \\
\hline Cadmium & 1 & MW-10-2 & $\mathrm{U}$ & & $8 / 1 / 06$ & $8 / 23 / 06$ & WCF164012X & $7440-43-9$ \\
\hline Cadmium & 1 & MW-2 & $\mathrm{U}$ & & $8 / 1 / 06$ & $8 / 23 / 06$ & WCF160012X & $7440-43-9$ \\
\hline Carbon disulfide & 1 & CРP-33-1 & $\mathrm{U}$ & & $7 / 31 / 06$ & $8 / 10 / 06$ & WCF15901VA & $75-15-0$ \\
\hline Carbon disulfide & 1 & CPP-55-06 & $\mathrm{U}$ & & $7 / 31 / 06$ & $8 / 10 / 06$ & WCF16301VA & $75-15-0$ \\
\hline Carbon disulfide & 1 & ICPP-2018 & $\mathrm{U}$ & & $8 / 2 / 06$ & $8 / 10 / 06$ & WCF16101VA & $75-15-0$ \\
\hline Carbon disulfide & 1 & ICPP-2019 & $\mathrm{U}$ & & $8 / 2 / 06$ & $8 / 10 / 06$ & WCF16201VA & $75-15-0$ \\
\hline Carbon disulfide & 1 & ICPP-2019 & $\mathrm{U}$ & & $8 / 2 / 06$ & $8 / 10 / 06$ & WCF16202VA & $75-15-0$ \\
\hline Carbon disulfide & 1 & MW-10-2 & $\mathrm{U}$ & & $8 / 1 / 06$ & $8 / 10 / 06$ & WCF16401VA & $75-15-0$ \\
\hline Carbon disulfide & 1 & MW-2 & $\mathrm{U}$ & & $8 / 1 / 06$ & $8 / 11 / 06$ & WCF16001VA & $75-15-0$ \\
\hline Carbon disulfide & 1 & MW-5-2 & $\mathrm{U}$ & & $8 / 1 / 06$ & $8 / 10 / 06$ & WCF15601VA & $75-15-0$ \\
\hline Carbon tetrachloride & 1 & CPP-33-1 & $\mathrm{U}$ & & $7 / 31 / 06$ & $8 / 10 / 06$ & WCF15901VA & $56-23-5$ \\
\hline Carbon tetrachloride & 1 & CPP-55-06 & $\mathrm{U}$ & & $7 / 31 / 06$ & $8 / 10 / 06$ & WCF16301VA & $56-23-5$ \\
\hline Carbon tetrachloride & 1 & ICPP-2018 & $\mathrm{U}$ & & $8 / 2 / 06$ & $8 / 10 / 06$ & WCF16101VA & $56-23-5$ \\
\hline
\end{tabular}


Table B-2. (continued).

\begin{tabular}{|c|c|c|c|c|c|c|c|c|}
\hline Constituent & $\begin{array}{l}\text { Conc. } \\
(\mu \mathrm{g} / \mathrm{L})\end{array}$ & Location & $\begin{array}{c}\text { Lab } \\
\text { Qualifier }\end{array}$ & $\begin{array}{l}\text { Validation } \\
\text { Qualifier }\end{array}$ & $\begin{array}{c}\text { Date } \\
\text { Collected } \\
\end{array}$ & $\begin{array}{c}\text { Date } \\
\text { Analyzed } \\
\end{array}$ & Sample Number & $\begin{array}{c}\text { CAS } \\
\text { Number }\end{array}$ \\
\hline Carbon tetrachloride & 1 & ICPP-2019 & $\mathrm{U}$ & & $8 / 2 / 06$ & $8 / 10 / 06$ & WCF16201VA & $56-23-5$ \\
\hline Carbon tetrachloride & 1 & ICPP-2019 & $\mathrm{U}$ & & $8 / 2 / 06$ & $8 / 10 / 06$ & WCF16202VA & $56-23-5$ \\
\hline Carbon tetrachloride & 1 & MW-10-2 & $\mathrm{U}$ & & $8 / 1 / 06$ & $8 / 10 / 06$ & WCF16401VA & $56-23-5$ \\
\hline Carbon tetrachloride & 1 & MW-2 & $\mathrm{U}$ & & $8 / 1 / 06$ & $8 / 11 / 06$ & WCF16001VA & $56-23-5$ \\
\hline Carbon tetrachloride & 1 & MW-5-2 & $\mathrm{U}$ & & $8 / 1 / 06$ & $8 / 10 / 06$ & WCF15601VA & $56-23-5$ \\
\hline Chloroform & 1 & CPP-33-1 & $\mathrm{U}$ & & $7 / 31 / 06$ & $8 / 10 / 06$ & WCF15901VA & $67-66-3$ \\
\hline Chloroform & 1 & CPP-55-06 & $\mathrm{U}$ & & $7 / 31 / 06$ & $8 / 10 / 06$ & WCF16301VA & $67-66-3$ \\
\hline Chloroform & 1 & ICPP-2018 & $\mathrm{U}$ & & $8 / 2 / 06$ & $8 / 10 / 06$ & WCF16101VA & $67-66-3$ \\
\hline Chloroform & 1 & ICPP-2019 & $\mathrm{U}$ & & $8 / 2 / 06$ & $8 / 10 / 06$ & WCF16201VA & $67-66-3$ \\
\hline Chloroform & 1 & ICPP-2019 & $\mathrm{U}$ & & $8 / 2 / 06$ & $8 / 10 / 06$ & WCF16202VA & $67-66-3$ \\
\hline Chloroform & 1 & MW-10-2 & $\mathrm{U}$ & & $8 / 1 / 06$ & $8 / 10 / 06$ & WCF16401VA & $67-66-3$ \\
\hline Chloroform & 1 & MW-2 & $\mathrm{U}$ & & $8 / 1 / 06$ & $8 / 11 / 06$ & WCF16001VA & $67-66-3$ \\
\hline Chloroform & 1 & MW-5-2 & $\mathrm{U}$ & & $8 / 1 / 06$ & $8 / 10 / 06$ & WCF15601VA & $67-66-3$ \\
\hline Chromium & 10 & CPP-33-1 & & & $7 / 31 / 06$ & $8 / 23 / 06$ & WCF159012X & $7440-47-3$ \\
\hline Chromium & 4.9 & СРP-55-06 & $\mathrm{B}$ & & $7 / 31 / 06$ & $8 / 23 / 06$ & WCF163012X & $7440-47-3$ \\
\hline Chromium & 2.5 & ICPP-2018 & $\mathrm{U}$ & & $8 / 2 / 06$ & $8 / 23 / 06$ & WCF161012X & $7440-47-3$ \\
\hline Chromium & 5.4 & ICPP-2019 & $\mathrm{B}$ & & $8 / 2 / 06$ & $8 / 23 / 06$ & WCF162012X & $7440-47-3$ \\
\hline Chromium & 4.9 & ICPP-2019 & $\mathrm{B}$ & & $8 / 2 / 06$ & $8 / 23 / 06$ & WCF162022X & $7440-47-3$ \\
\hline Chromium & 2.5 & MW-10-2 & $\mathrm{U}$ & & $8 / 1 / 06$ & $8 / 23 / 06$ & WCF164012X & $7440-47-3$ \\
\hline Chromium & 6.2 & MW-2 & $\mathrm{B}$ & & $8 / 1 / 06$ & $8 / 23 / 06$ & WCF160012X & $7440-47-3$ \\
\hline cis-1,2-Dichloroethene & 1 & CPP-33-1 & $\mathrm{U}$ & & $7 / 31 / 06$ & $8 / 10 / 06$ & WCF15901VA & $156-59-2$ \\
\hline cis-1,2-Dichloroethene & 1 & CPP-55-06 & $\mathrm{U}$ & & $7 / 31 / 06$ & $8 / 10 / 06$ & WCF16301VA & $156-59-2$ \\
\hline cis-1,2-Dichloroethene & 1 & ICPP-2018 & $\mathrm{U}$ & & $8 / 2 / 06$ & $8 / 10 / 06$ & WCF16101VA & $156-59-2$ \\
\hline cis-1,2-Dichloroethene & 1 & ICPP-2019 & $\mathrm{U}$ & & $8 / 2 / 06$ & $8 / 10 / 06$ & WCF16201VA & $156-59-2$ \\
\hline cis-1,2-Dichloroethene & 1 & ICPP-2019 & $\mathrm{U}$ & & $8 / 2 / 06$ & $8 / 10 / 06$ & WCF16202VA & $156-59-2$ \\
\hline cis-1,2-Dichloroethene & 1 & MW-10-2 & $\mathrm{U}$ & & $8 / 1 / 06$ & $8 / 10 / 06$ & WCF16401VA & $156-59-2$ \\
\hline cis-1,2-Dichloroethene & 1 & MW-2 & $\mathrm{U}$ & & $8 / 1 / 06$ & $8 / 11 / 06$ & WCF16001VA & $156-59-2$ \\
\hline cis-1,2-Dichloroethene & 1 & MW-5-2 & $\mathrm{U}$ & & $8 / 1 / 06$ & $8 / 10 / 06$ & WCF15601VA & $156-59-2$ \\
\hline
\end{tabular}


Table B-2. (continued).

\begin{tabular}{|c|c|c|c|c|c|c|c|c|}
\hline Constituent & $\begin{array}{l}\text { Conc. } \\
(\mu \mathrm{g} / \mathrm{L})\end{array}$ & Location & $\begin{array}{c}\text { Lab } \\
\text { Qualifier }\end{array}$ & $\begin{array}{c}\text { Validation } \\
\text { Qualifier }\end{array}$ & $\begin{array}{c}\text { Date } \\
\text { Collected } \\
\end{array}$ & $\begin{array}{c}\text { Date } \\
\text { Analyzed } \\
\end{array}$ & Sample Number & $\begin{array}{c}\text { CAS } \\
\text { Number }\end{array}$ \\
\hline trans-1,2-Dichloroethene & 1 & CPP-33-1 & $\mathrm{U}$ & & $7 / 31 / 06$ & $8 / 10 / 06$ & WCF15901VA & $156-60-5$ \\
\hline trans-1,2-Dichloroethene & 1 & CPP-55-06 & $\mathrm{U}$ & & $7 / 31 / 06$ & $8 / 10 / 06$ & WCF16301VA & $156-60-5$ \\
\hline trans-1,2-Dichloroethene & 1 & ICPP-2018 & $\mathrm{U}$ & & $8 / 2 / 06$ & $8 / 10 / 06$ & WCF16101VA & $156-60-5$ \\
\hline trans-1,2-Dichloroethene & 1 & ICPP-2019 & $\mathrm{U}$ & & $8 / 2 / 06$ & $8 / 10 / 06$ & WCF16201VA & $156-60-5$ \\
\hline trans-1,2-Dichloroethene & 1 & ICPP-2019 & $\mathrm{U}$ & & $8 / 2 / 06$ & $8 / 10 / 06$ & WCF16202VA & $156-60-5$ \\
\hline trans-1,2-Dichloroethene & 1 & MW-10-2 & $\mathrm{U}$ & & $8 / 1 / 06$ & $8 / 10 / 06$ & WCF16401VA & $156-60-5$ \\
\hline trans-1,2-Dichloroethene & 1 & MW-2 & $\mathrm{U}$ & & $8 / 1 / 06$ & $8 / 11 / 06$ & WCF16001VA & $156-60-5$ \\
\hline trans-1,2-Dichloroethene & 1 & MW-5-2 & $\mathrm{U}$ & & $8 / 1 / 06$ & $8 / 10 / 06$ & WCF15601VA & $156-60-5$ \\
\hline 1,4-Dioxane & 2.6 & CPP-33-1 & $\mathrm{U}$ & UJ & $7 / 31 / 06$ & $8 / 17 / 06$ & WCF15901SV & $123-91-1$ \\
\hline 1,4-Dioxane & 0.8 & CPP-55-06 & $\mathrm{J}$ & $\mathrm{J}$ & $7 / 31 / 06$ & $8 / 17 / 06$ & WCF16301SV & $123-91-1$ \\
\hline 1,4-Dioxane & 2.5 & ICPP-2018 & $\mathrm{U}$ & & $8 / 2 / 06$ & $8 / 17 / 06$ & WCF16101SV & $123-91-1$ \\
\hline 1,4-Dioxane & 2.4 & ICPP-2019 & $\mathrm{U}$ & UJ & $8 / 2 / 06$ & $8 / 17 / 06$ & WCF16201SV & $123-91-1$ \\
\hline 1,4-Dioxane & 2.5 & ICPP-2019 & $\mathrm{U}$ & & $8 / 2 / 06$ & $8 / 17 / 06$ & WCF16202SV & $123-91-1$ \\
\hline 1,4-Dioxane & 2.4 & MW-2 & $\mathrm{U}$ & & $8 / 1 / 06$ & $8 / 17 / 06$ & WCF16001SV & $123-91-1$ \\
\hline 1,4-Dioxane & 3.1 & MW-5-2 & $\mathrm{U}$ & UJ & $8 / 1 / 06$ & $8 / 17 / 06$ & WCF15601SV & $123-91-1$ \\
\hline Cyanide & 10 & СРP-33-1 & $\mathrm{U}$ & & $7 / 31 / 06$ & $8 / 14 / 06$ & WCF15901C2 & $57-12-5$ \\
\hline Cyanide & 10 & CPP-55-06 & $\mathrm{U}$ & & $7 / 31 / 06$ & $8 / 14 / 06$ & WCF16301C2 & $57-12-5$ \\
\hline Cyanide & 10 & ICPP-2018 & $\mathrm{U}$ & & $8 / 2 / 06$ & $8 / 14 / 06$ & WCF16101C2 & $57-12-5$ \\
\hline Cyanide & 10 & ICPP-2019 & $\mathrm{U}$ & & $8 / 2 / 06$ & $8 / 14 / 06$ & WCF16201C2 & $57-12-5$ \\
\hline Cyanide & 10 & ICPP-2019 & $\mathrm{U}$ & & $8 / 2 / 06$ & $8 / 14 / 06$ & WCF16202C2 & $57-12-5$ \\
\hline Cyanide & 10 & MW-2 & $\mathrm{U}$ & & $8 / 1 / 06$ & $8 / 14 / 06$ & WCF16001C2 & $57-12-5$ \\
\hline Cyanide & 10 & MW-5-2 & $\mathrm{U}$ & & $8 / 1 / 06$ & $8 / 14 / 06$ & WCF15601C2 & $57-12-5$ \\
\hline Formaldehyde & 232 & CРP-33-1 & $\mathrm{U}$ & $\mathrm{U}$ & $7 / 31 / 06$ & $8 / 4 / 06$ & WCF159012F & $50-00-0$ \\
\hline Formaldehyde & 232 & CPP-55-06 & $\mathrm{D}$ & $\mathrm{U}$ & $7 / 31 / 06$ & $8 / 4 / 06$ & WCF163012F & $50-00-0$ \\
\hline Formaldehyde & 140 & ICPP-2018 & $\mathrm{D}$ & $\mathrm{J}$ & $8 / 2 / 06$ & $8 / 4 / 06$ & WCF161012F & $50-00-0$ \\
\hline Formaldehyde & 232 & ICPP-2019 & $\mathrm{U}$ & $\mathrm{U}$ & $8 / 2 / 06$ & $8 / 4 / 06$ & WCF162012F & $50-00-0$ \\
\hline Formaldehyde & 232 & ICPP-2019 & $\mathrm{U}$ & $\mathrm{U}$ & $8 / 2 / 06$ & $8 / 4 / 06$ & WCF162022F & $50-00-0$ \\
\hline Formaldehyde & 232 & MW-2 & $\mathrm{U}$ & $\mathrm{U}$ & $8 / 1 / 06$ & $8 / 4 / 06$ & WCF160012F & $50-00-0$ \\
\hline
\end{tabular}


Table B-2. (continued).

\begin{tabular}{|c|c|c|c|c|c|c|c|c|}
\hline Constituent & $\begin{array}{l}\text { Conc. } \\
(\mu \mathrm{g} / \mathrm{L})\end{array}$ & Location & $\begin{array}{c}\text { Lab } \\
\text { Qualifier }\end{array}$ & $\begin{array}{c}\text { Validation } \\
\text { Qualifier }\end{array}$ & $\begin{array}{c}\text { Date } \\
\text { Collected } \\
\end{array}$ & $\begin{array}{c}\text { Date } \\
\text { Analyzed }\end{array}$ & Sample Number & $\begin{array}{c}\text { CAS } \\
\text { Number }\end{array}$ \\
\hline Formaldehyde & 232 & MW-5-2 & $\mathrm{U}$ & U & $8 / 1 / 06$ & $8 / 4 / 06$ & WCF156012F & $50-00-0$ \\
\hline Hydrazine & 5 & CPP-33-1 & $\mathrm{U}$ & & $7 / 31 / 06$ & $8 / 1 / 06$ & WCF159014H & $302-01-2$ \\
\hline Hydrazine & 5 & CPP-55-06 & $\mathrm{U}$ & & $7 / 31 / 06$ & $8 / 1 / 06$ & WCF163014H & $302-01-2$ \\
\hline Hydrazine & 5 & ICPP-2018 & $\mathrm{U}$ & & $8 / 2 / 06$ & $8 / 3 / 06$ & WCF161014H & $302-01-2$ \\
\hline Hydrazine & 5 & ICPP-2019 & $\mathrm{U}$ & & $8 / 2 / 06$ & $8 / 3 / 06$ & WCF162014H & $302-01-2$ \\
\hline Hydrazine & 5 & ICPP-2019 & $\mathrm{U}$ & & $8 / 2 / 06$ & $8 / 3 / 06$ & WCF162024H & $302-01-2$ \\
\hline Hydrazine & 5 & MW-10-2 & $\mathrm{U}$ & & $8 / 1 / 06$ & $8 / 2 / 06$ & WCF164014H & $302-01-2$ \\
\hline Hydrazine & 5 & MW-2 & $\mathrm{U}$ & & $8 / 1 / 06$ & $8 / 2 / 06$ & WCF160014H & $302-01-2$ \\
\hline Hydrazine & 5 & MW-5-2 & $\mathrm{U}$ & & $8 / 1 / 06$ & $8 / 2 / 06$ & WCF156014H & $302-01-2$ \\
\hline Iodomethane & 2 & CPP-33-1 & $\mathrm{U}$ & & $7 / 31 / 06$ & $8 / 10 / 06$ & WCF15901VA & $74-88-4$ \\
\hline Iodomethane & 2 & CPP-55-06 & $\mathrm{U}$ & & $7 / 31 / 06$ & $8 / 10 / 06$ & WCF16301VA & 74-88-4 \\
\hline Iodomethane & 2 & ICPP-2018 & $\mathrm{U}$ & & $8 / 2 / 06$ & $8 / 10 / 06$ & WCF16101VA & 74-88-4 \\
\hline Iodomethane & 2 & ICPP-2019 & $\mathrm{U}$ & & $8 / 2 / 06$ & $8 / 10 / 06$ & WCF16201VA & 74-88-4 \\
\hline Iodomethane & 2 & ICPP-2019 & $\mathrm{U}$ & & $8 / 2 / 06$ & $8 / 10 / 06$ & WCF16202VA & $74-88-4$ \\
\hline Iodomethane & 2 & MW-10-2 & $\mathrm{U}$ & & $8 / 1 / 06$ & $8 / 10 / 06$ & WCF16401VA & $74-88-4$ \\
\hline Iodomethane & 2 & MW-2 & $\mathrm{U}$ & & $8 / 1 / 06$ & $8 / 11 / 06$ & WCF16001VA & $74-88-4$ \\
\hline Iodomethane & 2 & MW-5-2 & $\mathrm{U}$ & & $8 / 1 / 06$ & $8 / 10 / 06$ & WCF15601VA & 74-88-4 \\
\hline Isobutyl alcohol & 50 & CPP-33-1 & $\mathrm{U}$ & & $7 / 31 / 06$ & $8 / 7 / 06$ & WCF15901TQ & $78-83-1$ \\
\hline Isobutyl alcohol & 50 & CPP-55-06 & $\mathrm{U}$ & & $7 / 31 / 06$ & $8 / 7 / 06$ & WCF16301TQ & $78-83-1$ \\
\hline Isobutyl alcohol & 50 & ICPP-2018 & $\mathrm{U}$ & & $8 / 2 / 06$ & $8 / 7 / 06$ & WCF16101TQ & $78-83-1$ \\
\hline Isobutyl alcohol & 50 & ICPP-2019 & $\mathrm{U}$ & & $8 / 2 / 06$ & $8 / 7 / 06$ & WCF16201TQ & $78-83-1$ \\
\hline Isobutyl alcohol & 50 & ICPP-2019 & $\mathrm{U}$ & & $8 / 2 / 06$ & $8 / 7 / 06$ & WCF16202TQ & $78-83-1$ \\
\hline Isobutyl alcohol & 50 & MW-10-2 & $\mathrm{U}$ & & $8 / 1 / 06$ & $8 / 7 / 06$ & WCF16401TQ & $78-83-1$ \\
\hline Isobutyl alcohol & 50 & MW-2 & $\mathrm{U}$ & & $8 / 1 / 06$ & $8 / 7 / 06$ & WCF16001TQ & $78-83-1$ \\
\hline Isobutyl alcohol & 50 & MW-5-2 & $\mathrm{U}$ & & $8 / 1 / 06$ & $8 / 7 / 06$ & WCF15601TQ & $78-83-1$ \\
\hline Lead & 2.5 & CPP-33-1 & $\mathrm{U}$ & & $7 / 31 / 06$ & $8 / 23 / 06$ & WCF159012X & $7439-92-1$ \\
\hline Lead & 2.5 & CPP-55-06 & $\mathrm{U}$ & & $7 / 31 / 06$ & $8 / 23 / 06$ & WCF163012X & $7439-92-1$ \\
\hline Lead & 2.5 & ICPP-2018 & $\mathrm{U}$ & & $8 / 2 / 06$ & $8 / 23 / 06$ & WCF161012X & 7439-92-1 \\
\hline
\end{tabular}


Table B-2. (continued).

\begin{tabular}{|c|c|c|c|c|c|c|c|c|}
\hline Constituent & $\begin{array}{l}\text { Conc. } \\
(\mu \mathrm{g} / \mathrm{L})\end{array}$ & Location & $\begin{array}{c}\text { Lab } \\
\text { Qualifier }\end{array}$ & $\begin{array}{c}\text { Validation } \\
\text { Qualifier }\end{array}$ & $\begin{array}{c}\text { Date } \\
\text { Collected } \\
\end{array}$ & $\begin{array}{c}\text { Date } \\
\text { Analyzed }\end{array}$ & Sample Number & $\begin{array}{c}\text { CAS } \\
\text { Number }\end{array}$ \\
\hline Lead & 2.5 & ICPP-2019 & $\mathrm{U}$ & & $8 / 2 / 06$ & $8 / 23 / 06$ & WCF162012X & $7439-92-1$ \\
\hline Lead & 2.5 & ICPP-2019 & $\mathrm{U}$ & & $8 / 2 / 06$ & $8 / 23 / 06$ & WCF162022X & 7439-92-1 \\
\hline Lead & 2.5 & MW-10-2 & $\mathrm{U}$ & & $8 / 1 / 06$ & $8 / 23 / 06$ & WCF164012X & $7439-92-1$ \\
\hline Lead & 2.5 & MW-2 & $\mathrm{U}$ & & $8 / 1 / 06$ & $8 / 23 / 06$ & WCF160012X & $7439-92-1$ \\
\hline Mercury & 0.2 & CPP-33-1 & $\mathrm{U}$ & & $7 / 31 / 06$ & $8 / 21 / 06$ & WCF159012X & $7439-97-6$ \\
\hline Mercury & 0.2 & CPP-55-06 & $\mathrm{U}$ & & $7 / 31 / 06$ & $8 / 21 / 06$ & WCF163012X & $7439-97-6$ \\
\hline Mercury & 0.2 & ICPP-2018 & $\mathrm{U}$ & & $8 / 2 / 06$ & $8 / 21 / 06$ & WCF161012X & $7439-97-6$ \\
\hline Mercury & 0.2 & ICPP-2019 & $\mathrm{U}$ & & $8 / 2 / 06$ & $8 / 21 / 06$ & WCF162012X & $7439-97-6$ \\
\hline Mercury & 0.2 & ICPP-2019 & $\mathrm{U}$ & & $8 / 2 / 06$ & $8 / 21 / 06$ & WCF162022X & $7439-97-6$ \\
\hline Mercury & 0.2 & MW-10-2 & $\mathrm{U}$ & & $8 / 1 / 06$ & $8 / 21 / 06$ & WCF164012X & $7439-97-6$ \\
\hline Mercury & 0.2 & MW-2 & $\mathrm{U}$ & & $8 / 1 / 06$ & $8 / 21 / 06$ & WCF160012X & $7439-97-6$ \\
\hline Methylene chloride & 1 & CPP-33-1 & $\mathrm{U}$ & & $7 / 31 / 06$ & $8 / 10 / 06$ & WCF15901VA & $75-09-2$ \\
\hline Methylene chloride & 1 & CPP-55-06 & $\mathrm{U}$ & & $7 / 31 / 06$ & $8 / 10 / 06$ & WCF16301VA & $75-09-2$ \\
\hline Methylene chloride & 1 & ICPP-2018 & $\mathrm{U}$ & & $8 / 2 / 06$ & $8 / 10 / 06$ & WCF16101VA & $75-09-2$ \\
\hline Methylene chloride & 1 & ICPP-2019 & $\mathrm{U}$ & & $8 / 2 / 06$ & $8 / 10 / 06$ & WCF16201VA & $75-09-2$ \\
\hline Methylene chloride & 1 & ICPP-2019 & $\mathrm{U}$ & & $8 / 2 / 06$ & $8 / 10 / 06$ & WCF16202VA & $75-09-2$ \\
\hline Methylene chloride & 1 & MW-10-2 & $\mathrm{U}$ & & $8 / 1 / 06$ & $8 / 10 / 06$ & WCF16401VA & $75-09-2$ \\
\hline Methylene chloride & 1 & MW-2 & $\mathrm{U}$ & & $8 / 1 / 06$ & $8 / 11 / 06$ & WCF16001VA & $75-09-2$ \\
\hline Methylene chloride & 1 & MW-5-2 & $\mathrm{U}$ & & $8 / 1 / 06$ & $8 / 10 / 06$ & WCF15601VA & $75-09-2$ \\
\hline Methyl ethyl ketone & 1 & СРP-33-1 & $\mathrm{U}$ & & $7 / 31 / 06$ & $8 / 10 / 06$ & WCF15901VA & $78-93-3$ \\
\hline Methyl ethyl ketone & 1 & CPP-55-06 & $\mathrm{U}$ & & $7 / 31 / 06$ & $8 / 10 / 06$ & WCF16301VA & $78-93-3$ \\
\hline Methyl ethyl ketone & 1 & ICPP-2018 & $\mathrm{U}$ & & $8 / 2 / 06$ & $8 / 10 / 06$ & WCF16101VA & 78-93-3 \\
\hline Methyl ethyl ketone & 1 & ICPP-2019 & $\mathrm{U}$ & & $8 / 2 / 06$ & $8 / 10 / 06$ & WCF16201VA & $78-93-3$ \\
\hline Methyl ethyl ketone & 1 & ICPP-2019 & $\mathrm{U}$ & & $8 / 2 / 06$ & $8 / 10 / 06$ & WCF16202VA & 78-93-3 \\
\hline Methyl ethyl ketone & 1 & MW-10-2 & $\mathrm{U}$ & & $8 / 1 / 06$ & $8 / 10 / 06$ & WCF16401VA & $78-93-3$ \\
\hline Methyl ethyl ketone & 1 & MW-2 & $\mathrm{U}$ & UJ & $8 / 1 / 06$ & $8 / 11 / 06$ & WCF16001VA & $78-93-3$ \\
\hline Methyl ethyl ketone & 2.1 & MW-5-2 & & & $8 / 1 / 06$ & $8 / 10 / 06$ & WCF15601VA & $78-93-3$ \\
\hline Phenol & 2.4 & CPP-33-1 & $\mathrm{U}$ & & $7 / 31 / 06$ & $8 / 18 / 06$ & WCF15901V9 & $108-95-2$ \\
\hline
\end{tabular}


Table B-2. (continued).

\begin{tabular}{|c|c|c|c|c|c|c|c|c|}
\hline Constituent & $\begin{array}{l}\text { Conc. } \\
(\mu \mathrm{g} / \mathrm{L})\end{array}$ & Location & $\begin{array}{c}\text { Lab } \\
\text { Qualifier }\end{array}$ & $\begin{array}{c}\text { Validation } \\
\text { Qualifier }\end{array}$ & $\begin{array}{c}\text { Date } \\
\text { Collected } \\
\end{array}$ & $\begin{array}{c}\text { Date } \\
\text { Analyzed }\end{array}$ & Sample Number & $\begin{array}{c}\text { CAS } \\
\text { Number }\end{array}$ \\
\hline Phenol & 2.4 & CPP-55-06 & $\mathrm{U}$ & & $7 / 31 / 06$ & $8 / 18 / 06$ & WCF16301V9 & $108-95-2$ \\
\hline Phenol & 2.5 & ICPP-2018 & $\mathrm{U}$ & & $8 / 2 / 06$ & $8 / 18 / 06$ & WCF16101V9 & $108-95-2$ \\
\hline Phenol & 2.4 & ICPP-2019 & $\mathrm{U}$ & & $8 / 2 / 06$ & $8 / 18 / 06$ & WCF16201V9 & $108-95-2$ \\
\hline Phenol & 2.4 & ICPP-2019 & $\mathrm{U}$ & & $8 / 2 / 06$ & $8 / 18 / 06$ & WCF16202V9 & $108-95-2$ \\
\hline Phenol & 2.5 & MW-2 & $\mathrm{U}$ & & $8 / 1 / 06$ & $8 / 18 / 06$ & WCF16001V9 & $108-95-2$ \\
\hline Phenol & 2.7 & MW-5-2 & $\mathrm{U}$ & & $8 / 1 / 06$ & $8 / 18 / 06$ & WCF15601V9 & $108-95-2$ \\
\hline Pyridine & 2.4 & CPP-33-1 & $\mathrm{U}$ & $\mathrm{R}$ & $7 / 31 / 06$ & $8 / 18 / 06$ & WCF15901V9 & $110-86-1$ \\
\hline Pyridine & 2.4 & CPP-55-06 & $\mathrm{U}$ & $\mathrm{R}$ & $7 / 31 / 06$ & $8 / 18 / 06$ & WCF16301V9 & $110-86-1$ \\
\hline Pyridine & 2.5 & ICPP-2018 & $\mathrm{U}$ & $\mathrm{R}$ & $8 / 2 / 06$ & $8 / 18 / 06$ & WCF16101V9 & $110-86-1$ \\
\hline Pyridine & 2.4 & ICPP-2019 & $\mathrm{U}$ & $\mathrm{R}$ & $8 / 2 / 06$ & $8 / 18 / 06$ & WCF16201V9 & $110-86-1$ \\
\hline Pyridine & 2.4 & ICPP-2019 & $\mathrm{U}$ & $\mathrm{R}$ & $8 / 2 / 06$ & $8 / 18 / 06$ & WCF16202V9 & $110-86-1$ \\
\hline Pyridine & 2.5 & MW-2 & $\mathrm{U}$ & $\mathrm{R}$ & $8 / 1 / 06$ & $8 / 18 / 06$ & WCF16001V9 & $110-86-1$ \\
\hline Pyridine & 2.7 & MW-5-2 & $\mathrm{U}$ & $\mathrm{R}$ & $8 / 1 / 06$ & $8 / 18 / 06$ & WCF15601V9 & $110-86-1$ \\
\hline Selenium & 5 & CPP-33-1 & $\mathrm{U}$ & & $7 / 31 / 06$ & $8 / 23 / 06$ & WCF159012X & $7782-49-2$ \\
\hline Selenium & 5 & CPP-55-06 & $\mathrm{U}$ & & $7 / 31 / 06$ & $8 / 23 / 06$ & WCF163012X & $7782-49-2$ \\
\hline Selenium & 5 & ICPP-2018 & U & & $8 / 2 / 06$ & $8 / 23 / 06$ & WCF161012X & $7782-49-2$ \\
\hline Selenium & 5 & ICPP-2019 & $\mathrm{U}$ & & $8 / 2 / 06$ & $8 / 23 / 06$ & WCF162012X & $7782-49-2$ \\
\hline Selenium & 5 & ICPP-2019 & $\mathrm{U}$ & & $8 / 2 / 06$ & $8 / 23 / 06$ & WCF162022X & $7782-49-2$ \\
\hline Selenium & 5 & MW-10-2 & $\mathrm{U}$ & & $8 / 1 / 06$ & $8 / 23 / 06$ & WCF164012X & $7782-49-2$ \\
\hline Selenium & 5 & MW-2 & $\mathrm{U}$ & & $8 / 1 / 06$ & $8 / 23 / 06$ & WCF160012X & $7782-49-2$ \\
\hline Silver & 2.5 & CPP-33-1 & $\mathrm{U}$ & & $7 / 31 / 06$ & $8 / 23 / 06$ & WCF159012X & $7440-22-4$ \\
\hline Silver & 2.5 & CРP-55-06 & $\mathrm{U}$ & & $7 / 31 / 06$ & $8 / 23 / 06$ & WCF163012X & $7440-22-4$ \\
\hline Silver & 2.5 & ICPP-2018 & $\mathrm{U}$ & & $8 / 2 / 06$ & $8 / 23 / 06$ & WCF161012X & $7440-22-4$ \\
\hline Silver & 2.5 & ICPP-2019 & $\mathrm{U}$ & & $8 / 2 / 06$ & $8 / 23 / 06$ & WCF162012X & $7440-22-4$ \\
\hline Silver & 2.5 & ICPP-2019 & $\mathrm{U}$ & & $8 / 2 / 06$ & $8 / 23 / 06$ & WCF162022X & $7440-22-4$ \\
\hline Silver & 2.5 & MW-10-2 & $\mathrm{U}$ & & $8 / 1 / 06$ & $8 / 23 / 06$ & WCF164012X & $7440-22-4$ \\
\hline Silver & 2.5 & MW-2 & $\mathrm{U}$ & & $8 / 1 / 06$ & $8 / 23 / 06$ & WCF160012X & $7440-22-4$ \\
\hline Tetrachloroethene & 1 & CPP-33-1 & $\mathrm{U}$ & UJ & $7 / 31 / 06$ & $8 / 10 / 06$ & WCF15901VA & $127-18-4$ \\
\hline
\end{tabular}


Table B-2. (continued).

\begin{tabular}{|c|c|c|c|c|c|c|c|c|}
\hline Constituent & $\begin{array}{l}\text { Conc. } \\
(\mu \mathrm{g} / \mathrm{L})\end{array}$ & Location & $\begin{array}{c}\text { Lab } \\
\text { Qualifier }\end{array}$ & $\begin{array}{l}\text { Validation } \\
\text { Qualifier }\end{array}$ & $\begin{array}{c}\text { Date } \\
\text { Collected } \\
\end{array}$ & $\begin{array}{c}\text { Date } \\
\text { Analyzed }\end{array}$ & Sample Number & $\begin{array}{c}\text { CAS } \\
\text { Number }\end{array}$ \\
\hline Tetrachloroethene & 1 & CPP-55-06 & $\mathrm{U}$ & UJ & $7 / 31 / 06$ & $8 / 10 / 06$ & WCF16301VA & $127-18-4$ \\
\hline Tetrachloroethene & 1 & ICPP-2018 & $\mathrm{U}$ & UJ & $8 / 2 / 06$ & $8 / 10 / 06$ & WCF16101VA & $127-18-4$ \\
\hline Tetrachloroethene & 1 & ICPP-2019 & $\mathrm{U}$ & UJ & $8 / 2 / 06$ & $8 / 10 / 06$ & WCF16201VA & $127-18-4$ \\
\hline Tetrachloroethene & 1 & ICPP-2019 & $\mathrm{U}$ & UJ & $8 / 2 / 06$ & $8 / 10 / 06$ & WCF16202VA & $127-18-4$ \\
\hline Tetrachloroethene & 3.3 & MW-10-2 & & $\mathrm{J}$ & $8 / 1 / 06$ & $8 / 10 / 06$ & WCF16401VA & $127-18-4$ \\
\hline Tetrachloroethene & 1 & MW-2 & $\mathrm{U}$ & & $8 / 1 / 06$ & $8 / 11 / 06$ & WCF16001VA & $127-18-4$ \\
\hline Tetrachloroethene & 1 & MW-5-2 & $\mathrm{U}$ & UJ & $8 / 1 / 06$ & $8 / 10 / 06$ & WCF15601VA & $127-18-4$ \\
\hline Toluene & 1 & CPP-33-1 & $\mathrm{U}$ & & $7 / 31 / 06$ & $8 / 10 / 06$ & WCF15901VA & $108-88-3$ \\
\hline Toluene & 1 & CPP-55-06 & $\mathrm{U}$ & & $7 / 31 / 06$ & $8 / 10 / 06$ & WCF16301VA & $108-88-3$ \\
\hline Toluene & 1 & ICPP-2018 & $\mathrm{U}$ & & $8 / 2 / 06$ & $8 / 10 / 06$ & WCF16101VA & $108-88-3$ \\
\hline Toluene & 1 & ICPP-2019 & $\mathrm{U}$ & & $8 / 2 / 06$ & $8 / 10 / 06$ & WCF16201VA & $108-88-3$ \\
\hline Toluene & 1 & ICPP-2019 & $\mathrm{U}$ & & $8 / 2 / 06$ & $8 / 10 / 06$ & WCF16202VA & $108-88-3$ \\
\hline Toluene & 17 & MW-10-2 & & & $8 / 1 / 06$ & $8 / 10 / 06$ & WCF16401VA & $108-88-3$ \\
\hline Toluene & 1 & MW-2 & $\mathrm{U}$ & & $8 / 1 / 06$ & $8 / 11 / 06$ & WCF16001VA & $108-88-3$ \\
\hline Toluene & 1 & MW-5-2 & $\mathrm{U}$ & & $8 / 1 / 06$ & $8 / 10 / 06$ & WCF15601VA & $108-88-3$ \\
\hline 1,1,1-Trichloroethane & 1 & CPP-33-1 & $\mathrm{U}$ & & $7 / 31 / 06$ & $8 / 10 / 06$ & WCF15901VA & $71-55-6$ \\
\hline 1,1,1-Trichloroethane & 1 & CPP-55-06 & $\mathrm{U}$ & & $7 / 31 / 06$ & $8 / 10 / 06$ & WCF16301VA & $71-55-6$ \\
\hline 1,1,1-Trichloroethane & 1 & ICPP-2018 & $\mathrm{U}$ & & $8 / 2 / 06$ & $8 / 10 / 06$ & WCF16101VA & $71-55-6$ \\
\hline 1,1,1-Trichloroethane & 1 & ICPP-2019 & $\mathrm{U}$ & & $8 / 2 / 06$ & $8 / 10 / 06$ & WCF16201VA & $71-55-6$ \\
\hline 1,1,1-Trichloroethane & 1 & ICPP-2019 & $\mathrm{U}$ & & $8 / 2 / 06$ & $8 / 10 / 06$ & WCF16202VA & $71-55-6$ \\
\hline 1,1,1-Trichloroethane & 1 & MW-10-2 & $\mathrm{U}$ & & $8 / 1 / 06$ & $8 / 10 / 06$ & WCF16401VA & $71-55-6$ \\
\hline 1,1,1-Trichloroethane & 1 & MW-2 & $\mathrm{U}$ & & $8 / 1 / 06$ & $8 / 11 / 06$ & WCF16001VA & $71-55-6$ \\
\hline 1,1,1-Trichloroethane & 1 & MW-5-2 & $\mathrm{U}$ & & $8 / 1 / 06$ & $8 / 10 / 06$ & WCF15601VA & $71-55-6$ \\
\hline 1,1,2-Trichloroethane & 1 & CPP-33-1 & $\mathrm{U}$ & & $7 / 31 / 06$ & $8 / 10 / 06$ & WCF15901VA & $79-00-5$ \\
\hline 1,1,2-Trichloroethane & 1 & CPP-55-06 & $\mathrm{U}$ & & $7 / 31 / 06$ & $8 / 10 / 06$ & WCF16301VA & $79-00-5$ \\
\hline 1,1,2-Trichloroethane & 1 & ICPP-2018 & $\mathrm{U}$ & & $8 / 2 / 06$ & $8 / 10 / 06$ & WCF16101VA & $79-00-5$ \\
\hline 1,1,2-Trichloroethane & 1 & ICPP-2019 & $\mathrm{U}$ & & $8 / 2 / 06$ & $8 / 10 / 06$ & WCF16201VA & $79-00-5$ \\
\hline 1,1,2-Trichloroethane & 1 & ICPP-2019 & $\mathrm{U}$ & & $8 / 2 / 06$ & $8 / 10 / 06$ & WCF16202VA & $79-00-5$ \\
\hline
\end{tabular}


Table B-2. (continued).

\begin{tabular}{|c|c|c|c|c|c|c|c|c|}
\hline Constituent & $\begin{array}{l}\text { Conc. } \\
(\mu \mathrm{g} / \mathrm{L})\end{array}$ & Location & $\begin{array}{c}\text { Lab } \\
\text { Qualifier }\end{array}$ & $\begin{array}{l}\text { Validation } \\
\text { Qualifier }\end{array}$ & $\begin{array}{c}\text { Date } \\
\text { Collected }\end{array}$ & $\begin{array}{c}\text { Date } \\
\text { Analyzed } \\
\end{array}$ & Sample Number & $\begin{array}{c}\text { CAS } \\
\text { Number }\end{array}$ \\
\hline 1,1,2-Trichloroethane & 1 & MW-10-2 & $\mathrm{U}$ & & $8 / 1 / 06$ & $8 / 10 / 06$ & WCF16401VA & $79-00-5$ \\
\hline 1,1,2-Trichloroethane & 1 & MW-2 & $\mathrm{U}$ & & $8 / 1 / 06$ & $8 / 11 / 06$ & WCF16001VA & $79-00-5$ \\
\hline 1,1,2-Trichloroethane & 1 & MW-5-2 & $\mathrm{U}$ & & $8 / 1 / 06$ & $8 / 10 / 06$ & WCF15601VA & $79-00-5$ \\
\hline Trichloroethene & 1 & СРP-33-1 & $\mathrm{U}$ & & $7 / 31 / 06$ & $8 / 10 / 06$ & WCF15901VA & $79-01-6$ \\
\hline Trichloroethene & 1 & CPP-55-06 & $\mathrm{U}$ & & $7 / 31 / 06$ & $8 / 10 / 06$ & WCF16301VA & $79-01-6$ \\
\hline Trichloroethene & 1 & ICPP-2018 & $\mathrm{U}$ & & $8 / 2 / 06$ & $8 / 10 / 06$ & WCF16101VA & $79-01-6$ \\
\hline Trichloroethene & 1 & ICPP-2019 & $\mathrm{U}$ & & $8 / 2 / 06$ & $8 / 10 / 06$ & WCF16201VA & $79-01-6$ \\
\hline Trichloroethene & 1 & ICPP-2019 & $\mathrm{U}$ & & $8 / 2 / 06$ & $8 / 10 / 06$ & WCF16202VA & $79-01-6$ \\
\hline Trichloroethene & 1 & MW-10-2 & $\mathrm{U}$ & & $8 / 1 / 06$ & $8 / 10 / 06$ & WCF16401VA & $79-01-6$ \\
\hline Trichloroethene & 1 & MW-2 & $\mathrm{U}$ & & $8 / 1 / 06$ & $8 / 11 / 06$ & WCF16001VA & $79-01-6$ \\
\hline Trichloroethene & 1 & MW-5-2 & $\mathrm{U}$ & & $8 / 1 / 06$ & $8 / 10 / 06$ & WCF15601VA & $79-01-6$ \\
\hline Vanadium & 3.3 & CPP-33-1 & $\mathrm{B}$ & & $7 / 31 / 06$ & $8 / 23 / 06$ & WCF159012X & $7440-62-2$ \\
\hline Vanadium & 2.5 & CPP-55-06 & $\mathrm{U}$ & & $7 / 31 / 06$ & $8 / 23 / 06$ & WCF163012X & $7440-62-2$ \\
\hline Vanadium & 2.5 & ICPP-2018 & $\mathrm{U}$ & & $8 / 2 / 06$ & $8 / 23 / 06$ & WCF161012X & $7440-62-2$ \\
\hline Vanadium & 2.5 & ICPP-2019 & $\mathrm{U}$ & & $8 / 2 / 06$ & $8 / 23 / 06$ & WCF162012X & $7440-62-2$ \\
\hline Vanadium & 2.5 & ICPP-2019 & $\mathrm{U}$ & & $8 / 2 / 06$ & $8 / 23 / 06$ & WCF162022X & $7440-62-2$ \\
\hline Vanadium & 2.5 & MW-10-2 & $\mathrm{U}$ & & $8 / 1 / 06$ & $8 / 23 / 06$ & WCF164012X & $7440-62-2$ \\
\hline Vanadium & 2.8 & MW-2 & $\mathrm{B}$ & & $8 / 1 / 06$ & $8 / 23 / 06$ & WCF160012X & $7440-62-2$ \\
\hline Vinyl chloride & 1 & CPP-33-1 & $\mathrm{U}$ & & $7 / 31 / 06$ & $8 / 10 / 06$ & WCF15901VA & $75-01-4$ \\
\hline Vinyl chloride & 1 & CPP-55-06 & $\mathrm{U}$ & & $7 / 31 / 06$ & $8 / 10 / 06$ & WCF16301VA & $75-01-4$ \\
\hline Vinyl chloride & 1 & ICPP-2018 & $\mathrm{U}$ & & $8 / 2 / 06$ & $8 / 10 / 06$ & WCF16101VA & $75-01-4$ \\
\hline Vinyl chloride & 1 & ICPP-2019 & $\mathrm{U}$ & & $8 / 2 / 06$ & $8 / 10 / 06$ & WCF16201VA & $75-01-4$ \\
\hline Vinyl chloride & 1 & ICPP-2019 & $\mathrm{U}$ & & $8 / 2 / 06$ & $8 / 10 / 06$ & WCF16202VA & $75-01-4$ \\
\hline Vinyl chloride & 1 & MW-10-2 & $\mathrm{U}$ & & $8 / 1 / 06$ & $8 / 10 / 06$ & WCF16401VA & $75-01-4$ \\
\hline Vinyl chloride & 1 & MW-2 & $\mathrm{U}$ & & $8 / 1 / 06$ & $8 / 11 / 06$ & WCF16001VA & $75-01-4$ \\
\hline Vinyl chloride & 1 & MW-5-2 & $\mathrm{U}$ & & $8 / 1 / 06$ & $8 / 10 / 06$ & WCF15601VA & $75-01-4$ \\
\hline
\end{tabular}


Table B-3. Result qualifier and validation flag definitions.

\begin{tabular}{|c|c|c|}
\hline Compound & Flag & Definition \\
\hline & & Result Qualifier (lab-assigned flags) \\
\hline \multirow[t]{4}{*}{ Metals } & $\mathrm{U}$ & $\begin{array}{l}\text { Analyte was analyzed for but not detected. Analyte was below the contract } \\
\text { required detection limits. }\end{array}$ \\
\hline & $\mathrm{N}$ & $\begin{array}{l}\text { The associated matrix spike sample and/or the matrix spike duplicate sample } \\
\text { had a reported recovery outside of control limits }(80-120 \%) \text {. }\end{array}$ \\
\hline & $\mathrm{W}$ & $\begin{array}{l}\text { The associated analytical spike sample (the post-digestion spike sample) had a } \\
\text { reported recovery outside of control limits }(80-120 \%) \text {. }\end{array}$ \\
\hline & $\mathrm{B}$ & $\begin{array}{l}\text { Value less than contract required detection limit, but greater than or equal to the } \\
\text { Instrument Detection Limit. }\end{array}$ \\
\hline \multirow[t]{2}{*}{ VOCs } & $\mathrm{U}$ & $\begin{array}{l}\text { Analyte was analyzed for but not detected. Analyte result was below the } \\
\text { contract required detection limit. }\end{array}$ \\
\hline & $\mathrm{J}$ & Estimated value, greater than method detection limit but less than EQL. \\
\hline SVOCs & $\mathrm{U}$ & $\begin{array}{l}\text { Analyte was analyzed for but not detected. Analyte was below the contract } \\
\text { required detection limit. }\end{array}$ \\
\hline \multirow[t]{4}{*}{ Other } & $\mathrm{D}$ & Results indicate the value is from a diluted analysis. \\
\hline & $\mathrm{J}$ & Estimated value, greater than method detection limit but less than EQL. \\
\hline & $\mathrm{P}$ & $\begin{array}{l}\text { Results indicate that the percent difference between the reporting column and } \\
\text { the confirmation column exceeds quality control limits. }\end{array}$ \\
\hline & $\mathrm{U}$ & $\begin{array}{l}\text { Analyte was analyzed for but not detected. Analyte result was below the } \\
\text { contract required detection limit. }\end{array}$ \\
\hline \multicolumn{3}{|r|}{ Validation (validator-assigned flags) } \\
\hline \multirow[t]{3}{*}{ Metals } & $\mathrm{R}$ & $\begin{array}{l}\text { The accuracy of the data is so questionable that it is recommended the data not } \\
\text { be used. }\end{array}$ \\
\hline & $\mathrm{U}$ & $\begin{array}{l}\text { The constituent was analyzed for and was detected at or above the applicable } \\
\text { detection limit. However, the associated value was less than } 5 \text { times the highest } \\
\text { positive amount in any laboratory blank. }\end{array}$ \\
\hline & $\mathrm{J}$ & $\begin{array}{l}\text { The constituent was analyzed for and was detected at or above the applicable } \\
\text { detection limit. The associated value is an estimate and may be inaccurate or } \\
\text { imprecise. }\end{array}$ \\
\hline \multirow[t]{2}{*}{ VOCs } & $\mathrm{R}$ & $\begin{array}{l}\text { The accuracy of the data is so questionable that it is recommended the data not } \\
\text { be used. }\end{array}$ \\
\hline & UJ & $\begin{array}{l}\text { The constituent was analyzed for but was not detected. The sample quantitation } \\
\text { limit is an estimated value. }\end{array}$ \\
\hline SVOCs & UJ & $\begin{array}{l}\text { The constituent was analyzed for but was not detected. The sample quantitation } \\
\text { limit is an estimated value. }\end{array}$ \\
\hline \multirow[t]{2}{*}{ Other } & $\mathrm{U}$ & $\begin{array}{l}\text { Analyte was analyzed for and was detected at or above the applicable detection } \\
\text { limit but was qualified as nondetected at the reporting limit because the value } \\
\text { was less than the blank action level. }\end{array}$ \\
\hline & $\mathrm{J}$ & The constituent was analyzed for and the result is an estimated value. \\
\hline
\end{tabular}




\section{Appendix C}

Assessment of Perched Water Elevations and Hydraulic Gradients: November 2005 through September 2006 


$$
\text { C-2 }
$$




\section{Appendix C}

\section{Assessment of Perched Water Elevations and Hydraulic Gradients: November 2005 through September 2006}

Figure C-1 shows the approximate lateral extent of the northern shallow perched water during 2005-2006. Shallow perched water was present under most of the northern half of INTEC. Areas where shallow perched water was not observed during the reporting period include the central portion of the facility roughly between the dry fuel storage area and Binsets 1-3, and the extreme northeast part of INTEC. The perched water at INTEC tends to flow vertically downward but may also flow laterally where a horizontal hydraulic gradient exists and where low-permeability units are present that impede downward flow. Compared with groundwater flow in the underlying Snake River Plain Aquifer, flow paths in the perched water can be tortuous and difficult to predict.

Figure C-2 shows hydrographs for the WCF monitoring wells based on the bimonthly manual water level measurements. As in the past, wells CPP-33-1, CPP-33-2, and CPP-33-4-1 generally exhibited the highest water levels. Well CPP-33-2 showed a 3-ft drop in water level during October-November 2005 , but the water level completely recovered by January 2006. As in the past, the water level in well CPP-33-4-1 remained nearly constant. The lowest water levels were observed at MW-5-2, and the water level in this well continued to decline during 2006, reaching the lowest level since well installation. During the reporting period, water levels in MW-5-2 were more than $6 \mathrm{ft}$ lower than those in any other WCF monitoring well (Figure C-2). In contrast to MW-5-2, the water level in well MW-4-2 rose nearly $6 \mathrm{ft}$ during the reporting period. Well MW-4-2 had been dry prior to 2005 but contained approximately $8 \mathrm{ft}$ of water as of September 2006. The hydrographs for wells MW-2, CPP-55-06, and ICPP-2019 were nearly identical to each other (Figure C-2), which suggests that these wells are hydraulically connected and respond to the same recharge sources. The occurrence of upper shallow perched water beneath the northern portion of INTEC generally coincides with the depth of the 110-ft sedimentary interbed. Figure C-3 shows the elevation of the top of the 110-ft sedimentary interbed beneath the WCF area. As shown in this figure, the 110-ft interbed dips southeastward under this area.

Figure C-4 is a water level contour map for selected upper shallow perched wells on November 15, 2005. In this figure and subsequent water level contour maps, monitoring well CPP-33-1 was not used because it is screened at a shallower depth (above the upper shallow perched), and wells MW-8, MW-12-2, and MW-18-2 were not used because they were dry on all monitoring dates. Water level elevations are in units of feet above mean sea level (elevations relative to National Geodetic Vertical Datum of 1929).

The water level contour map for November 15, 2005, (Figure C-4) indicates that lateral flow in the shallow perched water beneath the northern INTEC area is generally to the southeast. This is consistent with similar data for the previous year. ${ }^{\text {T }}$ The inferred flow direction from the hydraulic gradient generally coincides with the southeasterly dip of the top of the 110-ft interbed beneath and south of the tank farm (Figure C-3). The water level contour map shows a steepening of the hydraulic gradient in the vicinity of MW-5-2, which had a much lower water level than the other wells.

a. DOE-ID, 2006, Fall 2005 Semiannual (III.H. and I.U.) Report for the HWMA/RCRA Post-Closure Permit for the INTEC Waste Calcining Facility at the INL Site, DOE/ID-11265, Rev. 0, U.S. Department of Energy Idaho Operations Office, January 2006. 


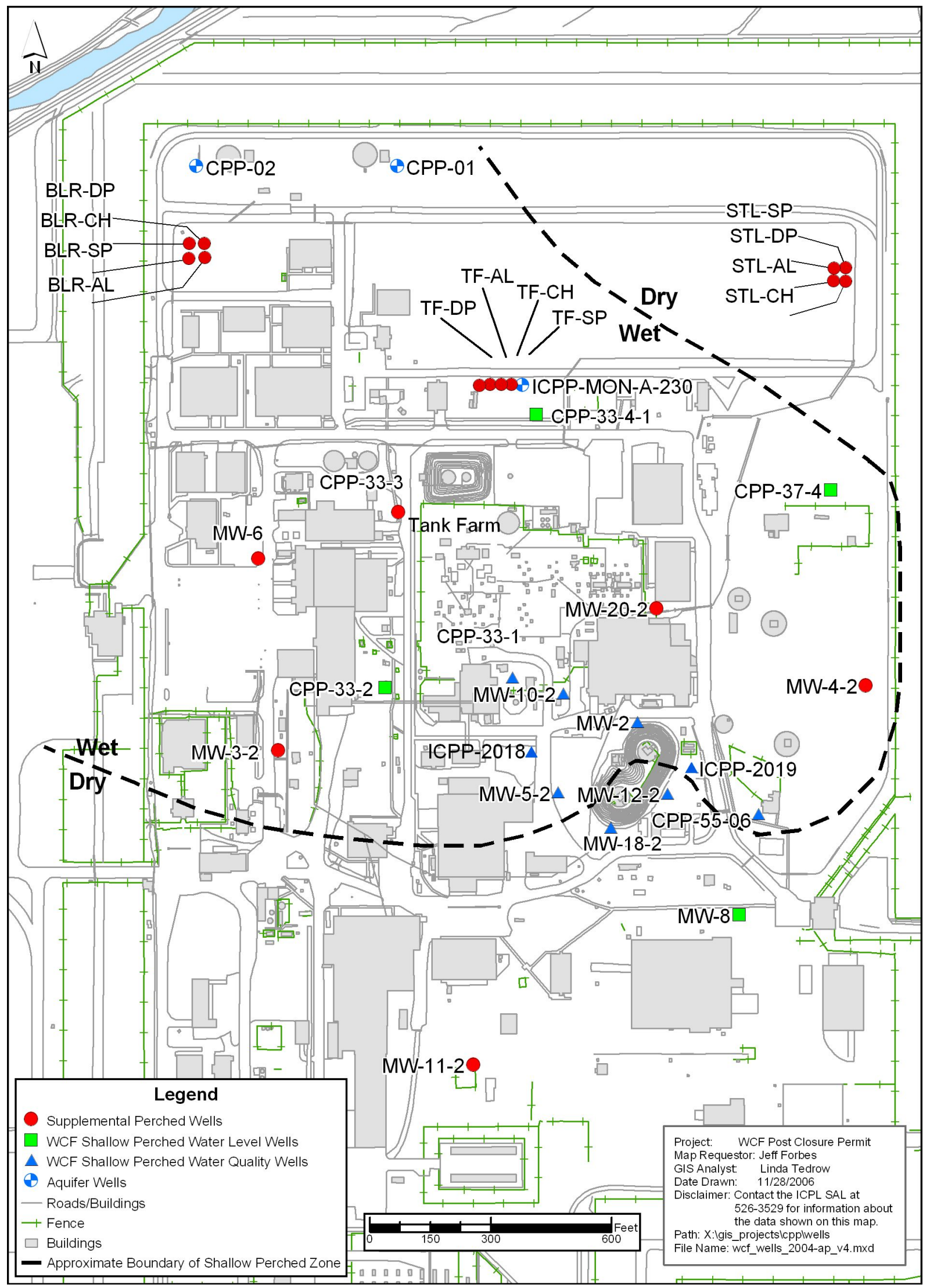

Figure C-1. Map showing lateral extent of northern shallow perched water zone during 2005-2006. 


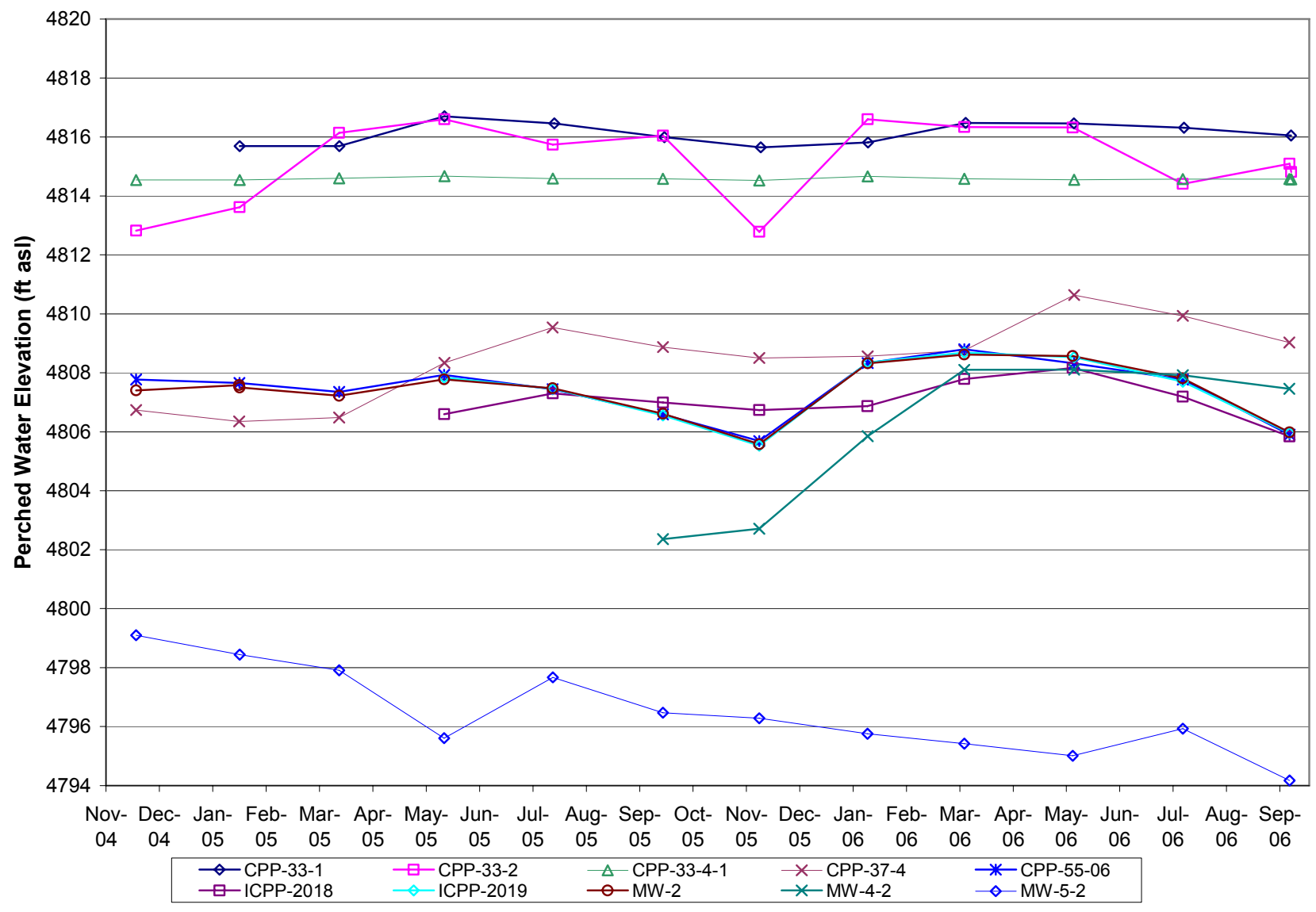

Figure C-2. Perched water hydrographs. 


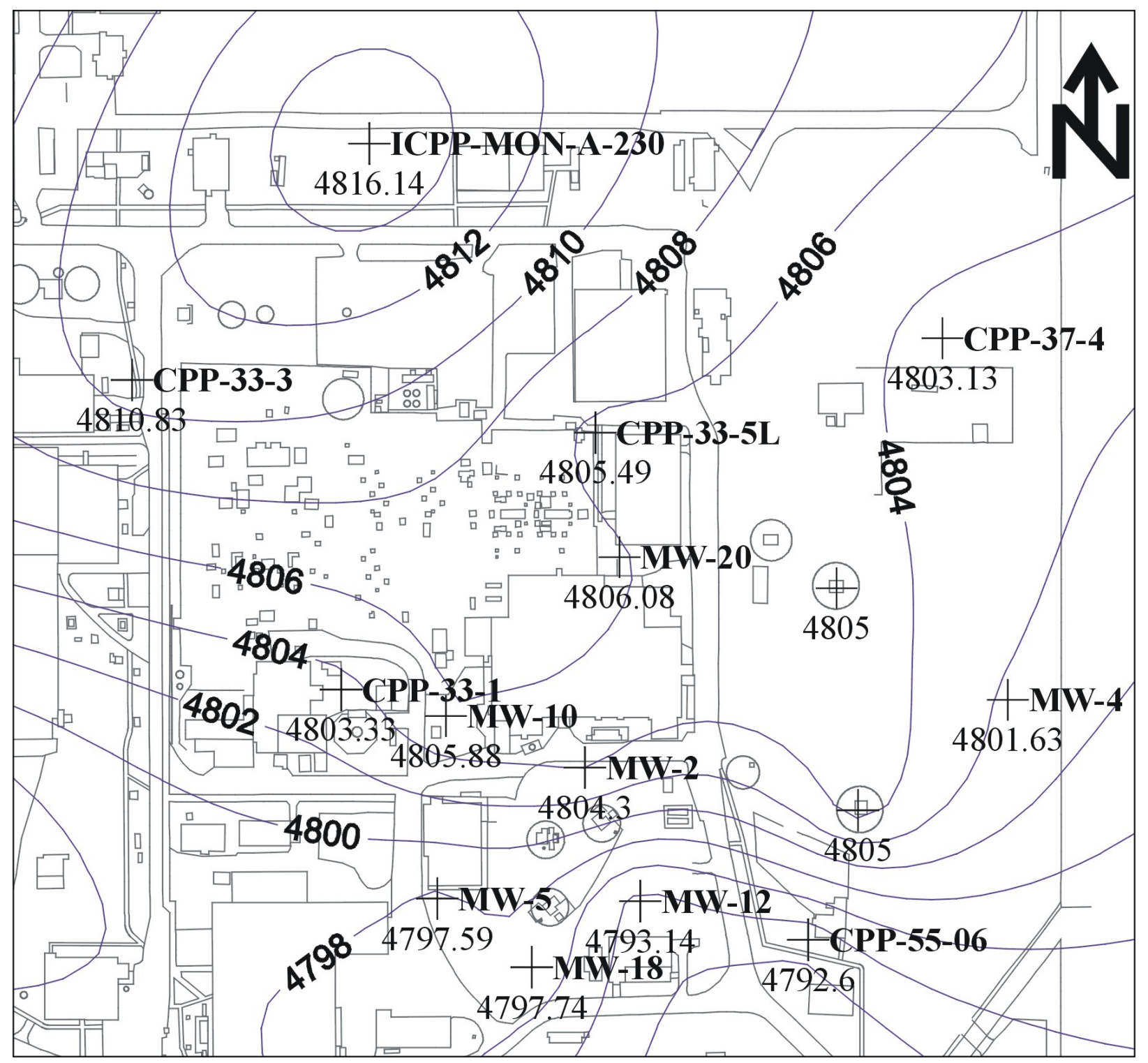

Figure C-3. Contour map of top of 110-ft sedimentary interbed. 


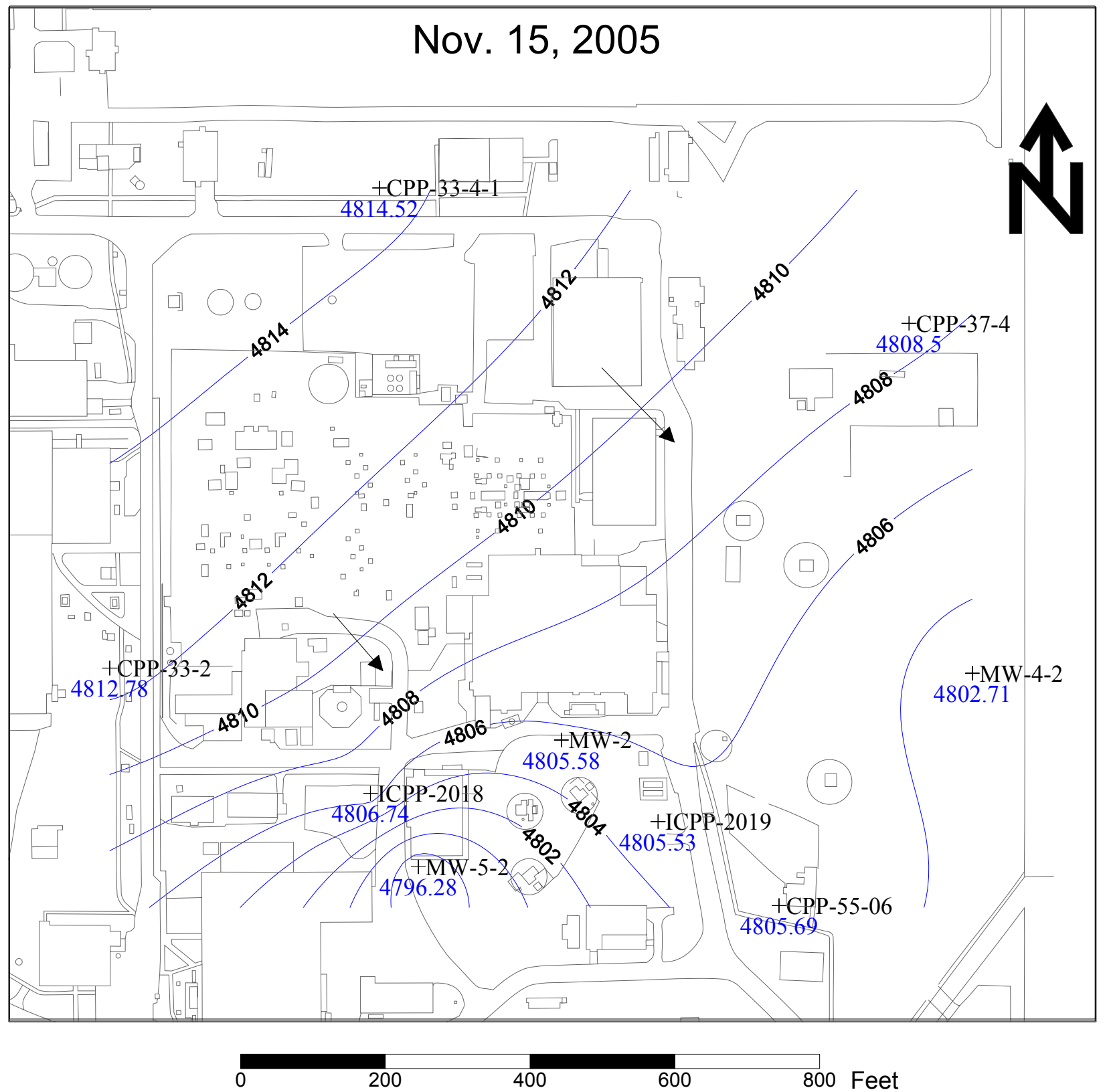

Figure C-4. Upper shallow perched water level contours for November 15, 2005. 
Figures C-5 through C-9 show water level contour maps for the January, March, May, July, and September 2006 monitoring dates. These maps are generally similar to one another, showing shallow perched water hydraulic gradient toward monitoring well MW-5-2. Because the much lower water levels in MW-5-2 suggest this well may not be directly comparable with the others, another water level contour map was prepared for September 19, 2006, that omits the MW-5-2 data (Figure C-10). This map is similar to the others, except that it does not show the concentric water level contours surrounding MW-5-2. It should be emphasized that downward vertical flow is also expected for the shallow perched water, but such vertical flow cannot be shown on the plan view water level maps.

The water level data for September 19, 2006, (Figure C-10) were used to calculate the inferred shallow perched water flow direction and horizontal hydraulic gradient. These calculations are based on the assumptions that the wells selected are hydraulically connected and are completed in the same continuous perched water zone. Because of uncertainties regarding these assumptions, the perched water flow calculations below should be used with caution. Well MW-5-2 was not used for this evaluation because, although it appears to be screened in the upper shallow perched zone, it is screened slightly deeper than the others (across the 110-ft interbed), and the water level in this well during 2006 was significantly lower than the other wells.

The perched water level contour map for September 19, 2006, (Figure C-10) shows a southeasterly hydraulic gradient ranging from 0.010 to $0.023 \mathrm{ft} / \mathrm{ft}$ to the southeast. A constant-rate pumping test performed on MW-5-2 during 1995 indicated a horizontal hydraulic conductivity $\left(\mathrm{K}_{\mathrm{H}}\right)$ of approximately $1.3 \times 10^{-3} \mathrm{~cm} / \mathrm{s} .{ }^{b}$ Current estimates of the effective porosity of the fractured basalt range from 0.03 to 0.05 . Assuming the latter value and substituting a hydraulic gradient of $0.02 \mathrm{ft} / \mathrm{ft}$ into Darcy's Equation gives the following estimate of perched water horizontal seepage velocity:

$\mathrm{V}_{\mathrm{H}}=\left(\mathrm{K}_{\mathrm{H}} * \mathrm{I}\right) / \mathrm{n}=\left(1.3 \times 10^{-3} \mathrm{~cm} / \mathrm{s} * 0.02\right) / 0.05=5.2 \times 10^{-4} \mathrm{~cm} / \mathrm{s}=0.5 \mathrm{~m} /$ day

where

$$
\begin{array}{lll}
\mathrm{V}_{\mathrm{H}} & =\text { horizontal seepage velocity }(\mathrm{cm} / \mathrm{s}) \\
\mathrm{K}_{\mathrm{H}} & =\text { horizontal hydraulic conductivity }(\mathrm{cm} / \mathrm{s}) \\
\mathrm{I} & =\text { horizontal hydraulic gradient (dimensionless) } \\
\mathrm{n} & =\text { effective porosity (dimensionless). }
\end{array}
$$

This calculation suggests perched water horizontal flow velocities of up to $0.5 \mathrm{~m} /$ day toward the southeast. Note that this calculation assumes an isotropic, porous medium, and this assumption is not valid for the fractured basalt. Actual flow velocities through joints in the basalt could be considerably faster than the calculated $0.5 \mathrm{~m} /$ day.

b. DOE-ID, 1997, Comprehensive RI/FS for the Idaho Chemical Processing Plant OU 3-13 at the INEEL-Part A, RI/BRA Report (Final), DOE/ID-10534, U.S. Department of Energy Idaho Operations Office, November 1997. 


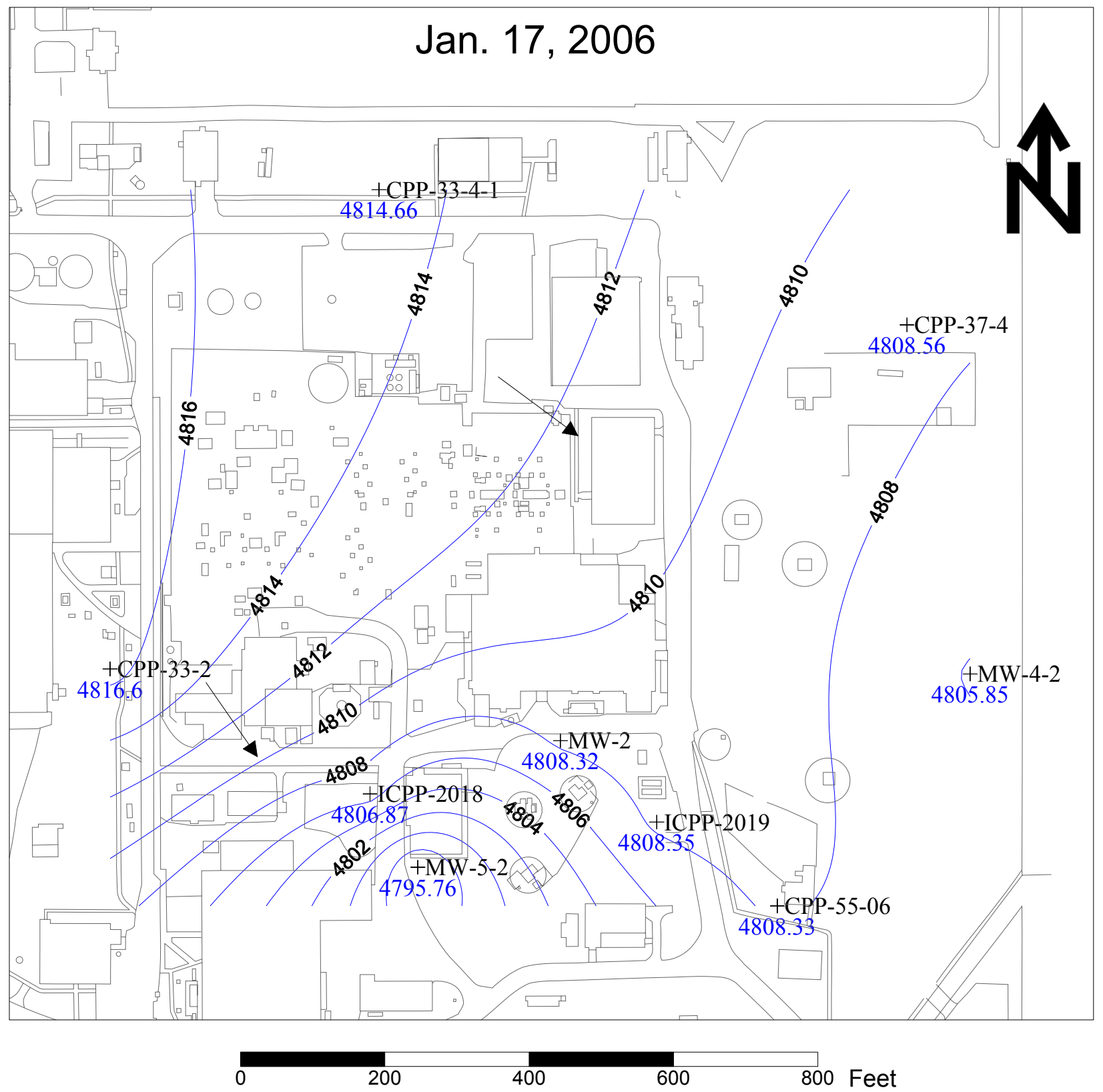

Figure C-5. Upper shallow perched water level contours for January 17, 2006. 


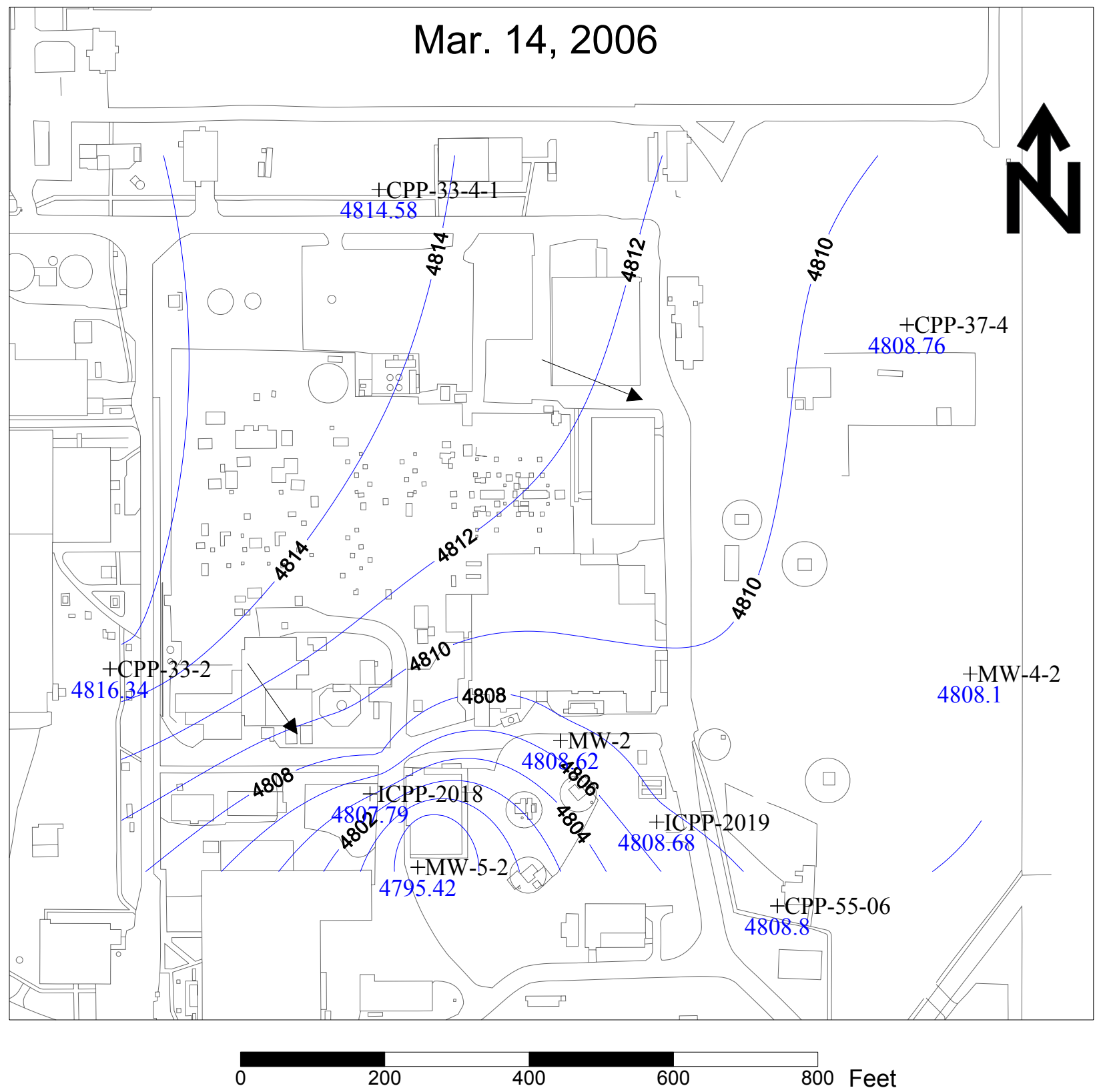

Figure C-6. Upper shallow perched water level contours for March 14, 2006. 


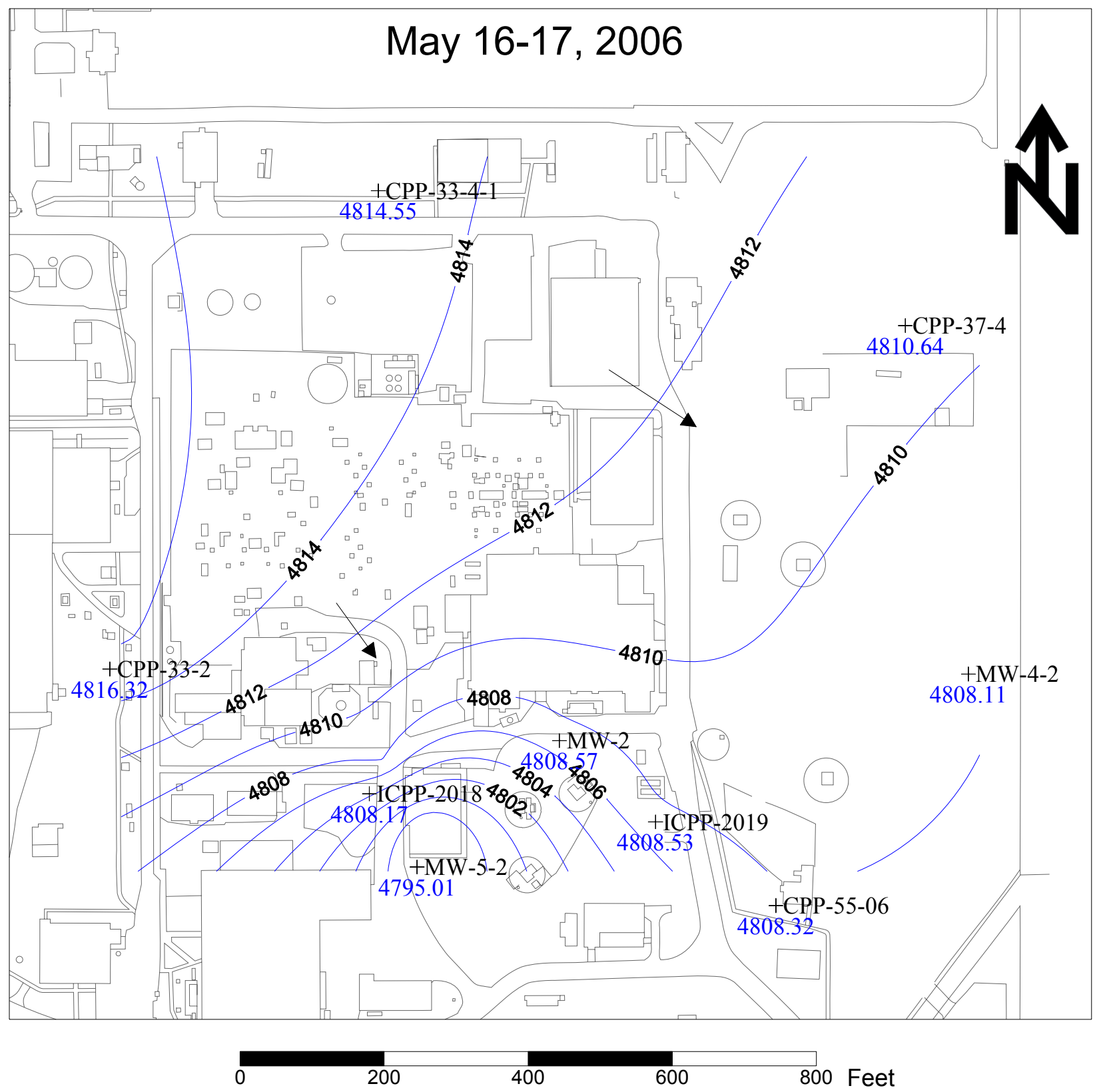

Figure C-7. Upper shallow perched water level contours for May 16-17, 2006. 


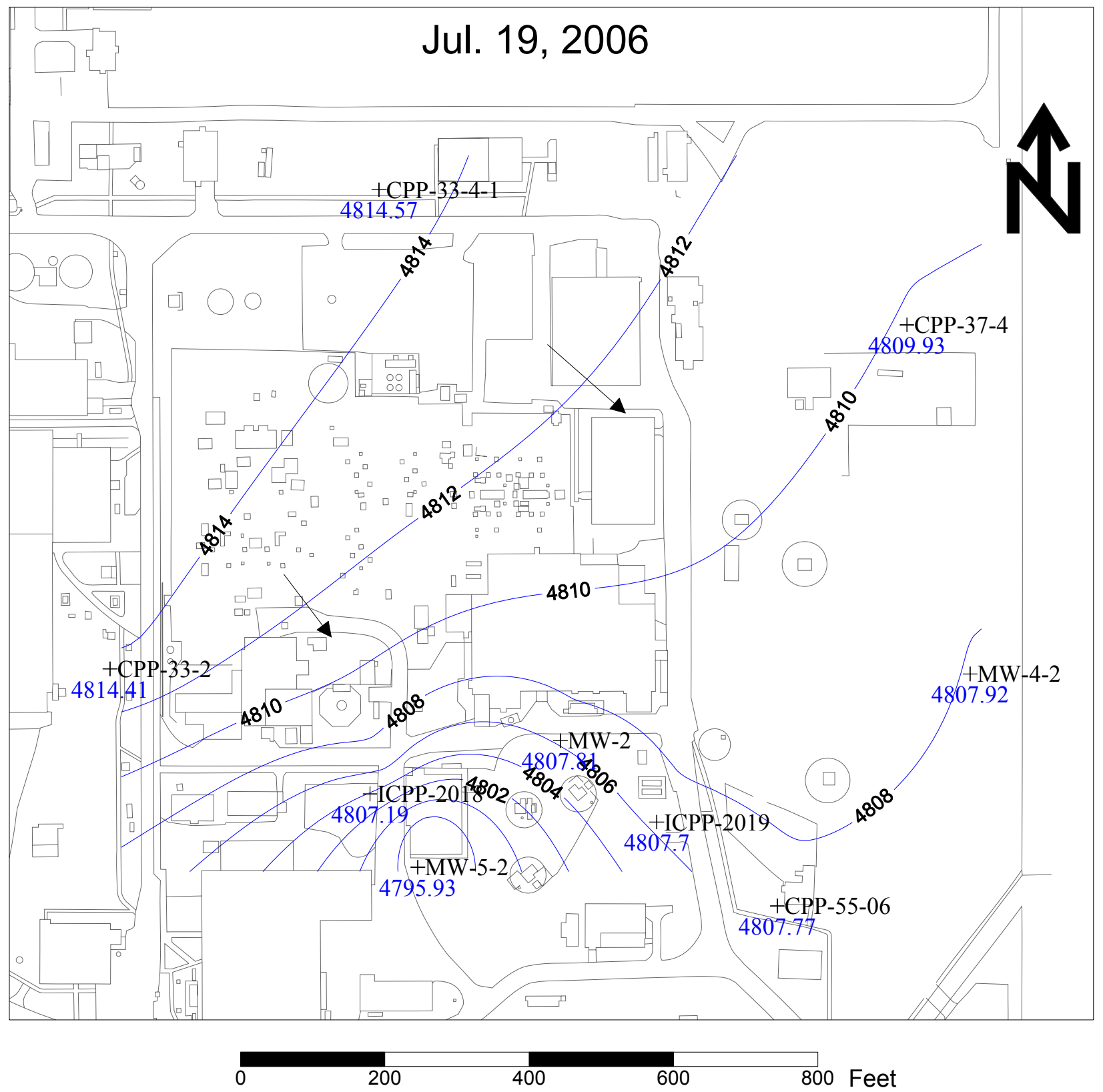

Figure C-8. Upper shallow perched water level contours for July 19, 2006. 


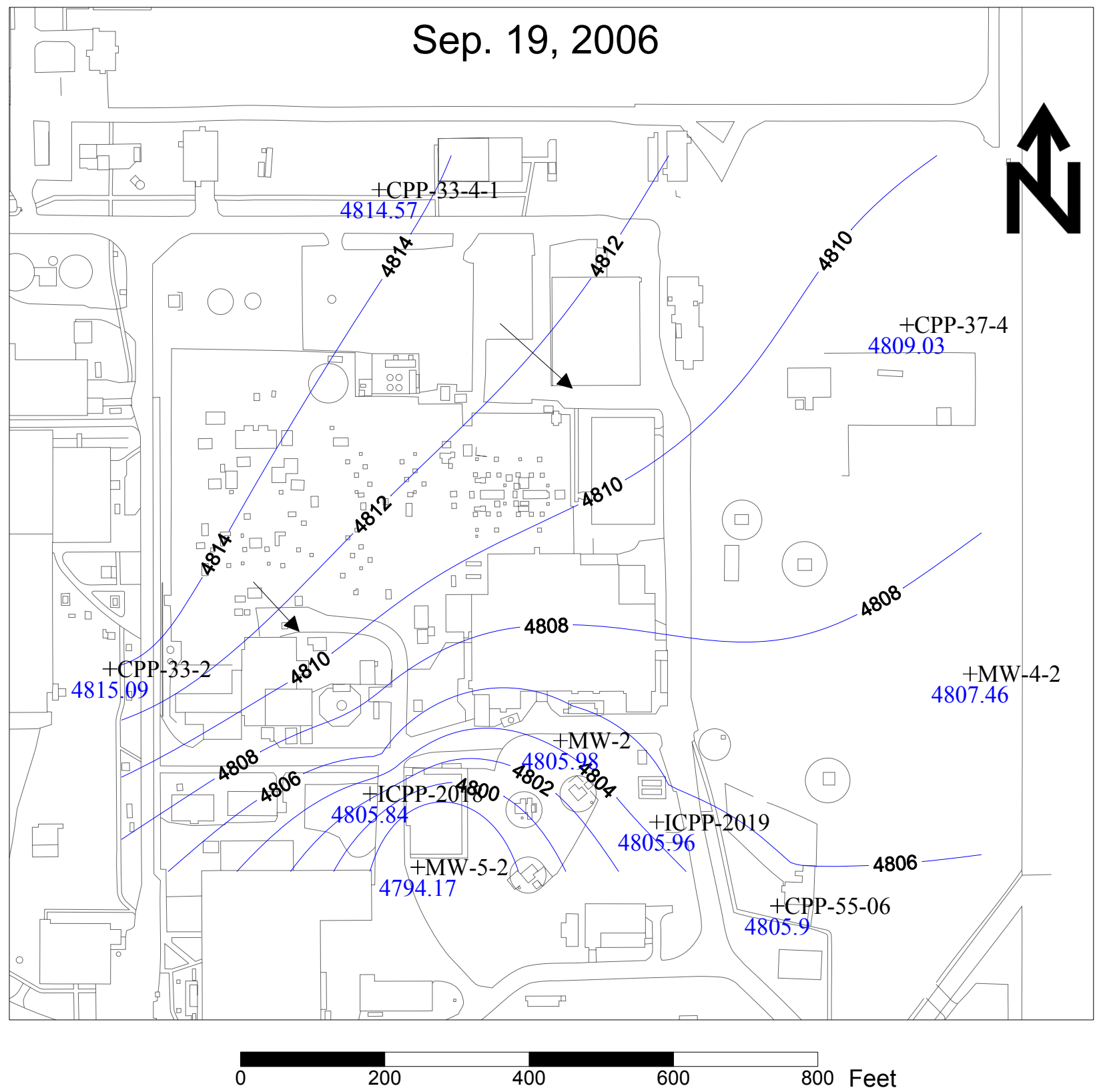

Figure C-9. Upper shallow perched water level contours for September 19, 2006. 


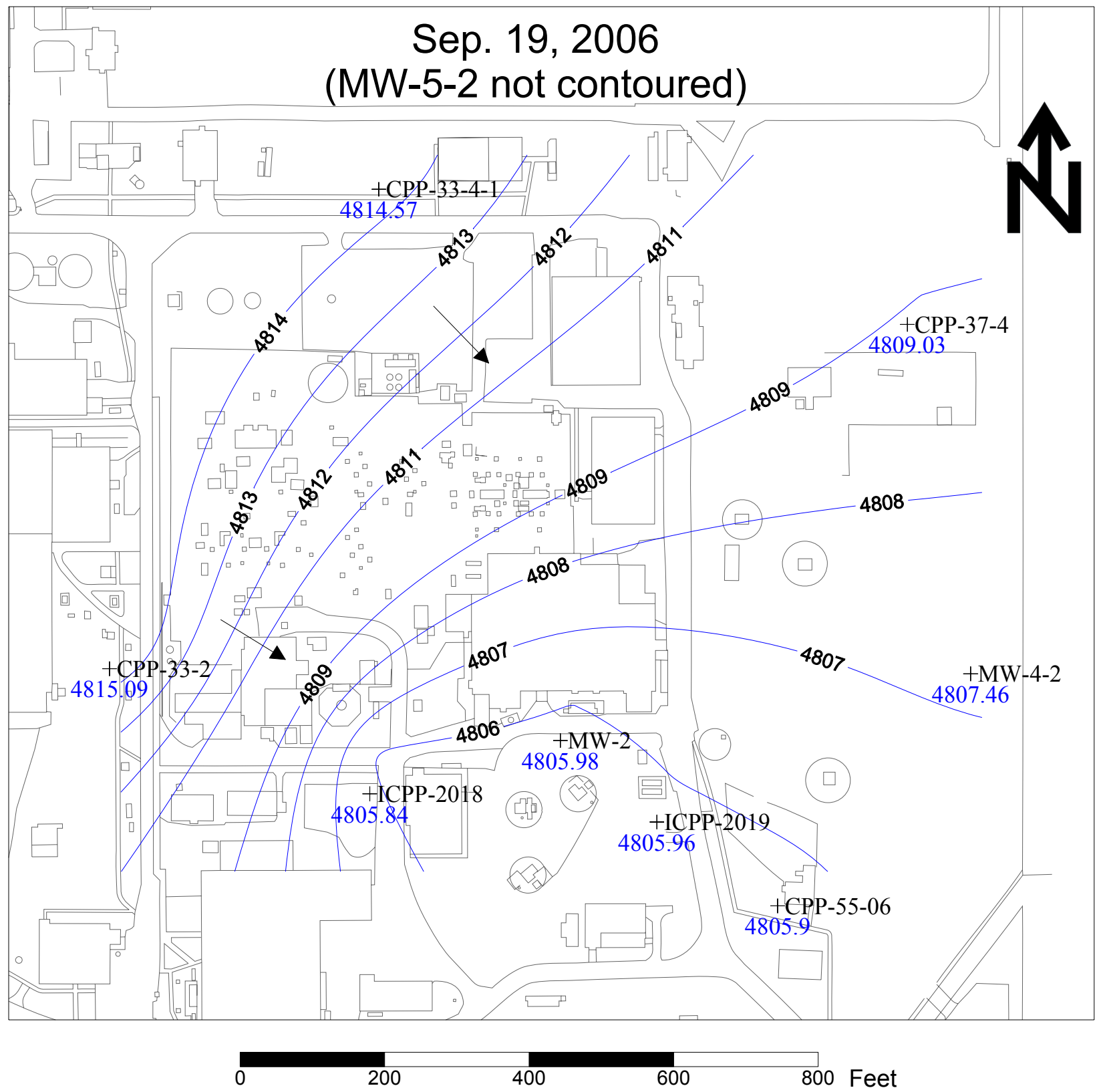

Figure C-10. Upper shallow perched water level contours for September 19, 2006; MW-5-2 not contoured. 